\title{
Antitrust and Economic History: The Historic Failure of the Chicago School of Antitrust
}

\author{
Mark Glick ${ }^{1}$
}

\section{Working Paper No. 95}

May 2019

\begin{abstract}
This paper presents an historical analysis of the antitrust laws. Its central contention is that the history of antitrust can only be understood in light of U.S. economic history and the succession of dominant economic policy regimes that punctuated that history. The antitrust laws and a subset of other related policies have historically focused on the negative consequences resulting from the rise, expansion, and dominance of big business. Antitrust specifically uses competition as its tool to address these problems. The paper traces the evolution of the emergence, growth and expansion of big business over six economic eras: the Gilded Age, the Progressive Era, the New Deal, the post-World War II Era, the 1970s, and the era of neoliberalism. It considers three policy regimes: laissez-faire during the Gilded Age and the Progressive Era, the New Deal, policy regime from the Depression through the early 1970s, and the neoliberal policy regime that dominates today and includes the Chicago School of antitrust. The principal conclusion of the paper is that the activist antitrust policies associated with the New Deal that existed from the late

\footnotetext{
${ }^{1}$ Professor, Department of Economics, University of Utah. Email: glick@economics.utah.edu. I would like to thank members of the University of Utah Competition Group, Catherine Ruetschlin, Marshall Steinbaum, and Ted Tatos for their help and input. I also benefited from suggestions and guidance from Gérard Duménil's 2019 seminar on economic history at the University of Utah. Doguhan Sundal provided valuable assistance on historical data sources. I also benefited from comments by Thomas Ferguson. Brandi Chase also provided assistance in preparing the final paper.
} 
1930s to the 1960s resulted in far stronger economic performance than have the policies of the Chicago School that have dominated antitrust policy since the 1980s.

JEL Codes: K21; L40; N12

Keywords: New Brandeis School, Antitrust economics, Antitrust law, Neoliberal Economic Theory, Chicago School Economics, History of Antitrust law 


\section{TABLE OF CONTENTS}

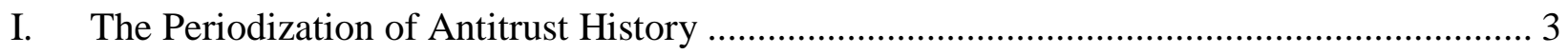

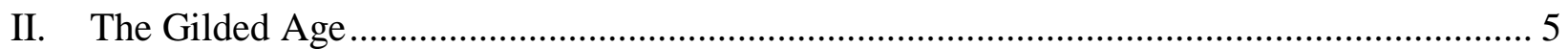

a. Industrialization and the Managerial Revolution........................................................ 5

b. Big Business, Bertrand Competition and Collusive Practices ......................................... 7

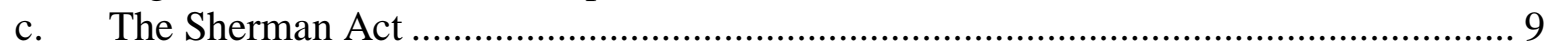

d. Early Sherman Act Enforcement ......................................................................... 11

III. The Progressive Era ................................................................................................... 12

a. The Corporate Revolution and the Rise of Finance.................................................... 13

1. The Early Merger Process.............................................................................. 13

2. The Merger Movement and Top Management ……………………………….. 15

3. The Merger Movement and Financial Control ……………………………….... 16

4. Antitrust Policy in the Progressive Era........................................................... 17

5. The Theodore Roosevelt Administration....................................................... 19

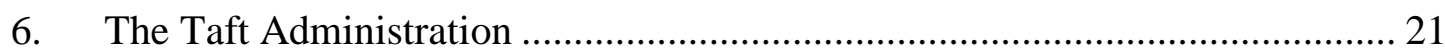

7. Woodrow Wilson and Louis Brandeis ............................................................. 21

b. The Rise of Instability and the Great Depression ...................................................... 25

1. Big Business, Finance and Instability …………………………………...... 26

2. Propagation of the Crash and the Policy Failures............................................ 28

IV. The New Deal and the Great Leap Forward ………......................................................... 30

a. The First Oder of Business: Suppress the Influence of Finance .................................. 30

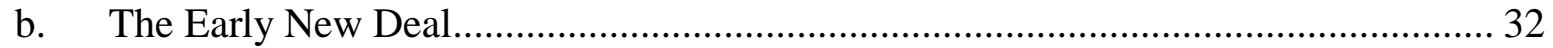

c. The Later New Deal.............................................................................................. 33

d. The Later New Deal and the Remarkable U.S. Economic Performance ..................... 35

e. World War II and Continued Success of the New Deal Policies.................................. 37

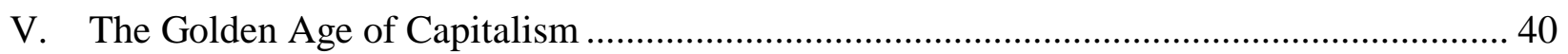

a. Antitrust in the Golden Age of Capitalism .............................................................. 42

b. The Origins of the Chicago School................................................................................ 43

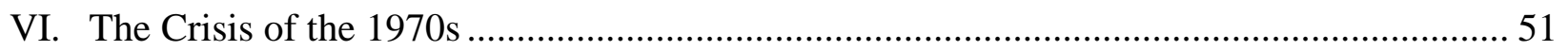

a. Economic Performance in the Crisis of the 1970s..................................................... 52

b. The Impact of the Crisis on the Incomes of the Wealthy and the Political Backlash. 53

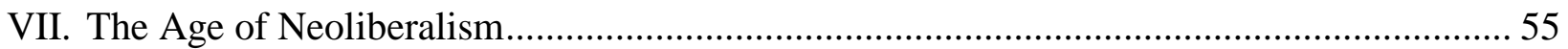

a. The Success of the Chicago School Antitrust Program ................................................ 56

1. Higher Concentration and Higher Profits ………………................................. 58

2. The Post Chicago School of Antitrust ............................................................... 60

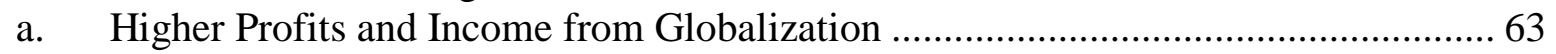

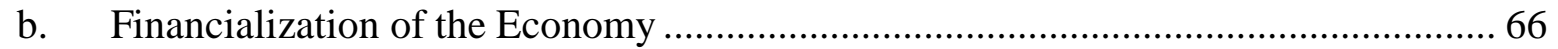

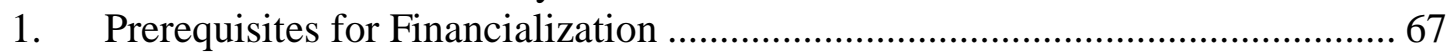

2. The Impact of Financialization: Diversion of Profits to Finance ..................... 71

c. An Assessment of Economic Performance under Neoliberalism ............................... 72

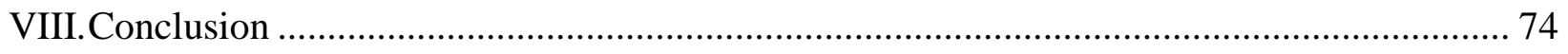


Antitrust policy has historically functioned as an integral part of a broader policy regime. These policy regimes are associated with distinct ideologies, which have evolved during different economic epochs in the United States. The assumptions of a prevailing policy regime guide individual actions and analyses of economic problems, while alternative approaches outside this framework are typically perceived as lacking in legitimacy. The struggle between different economic groups for political power shapes the dominant ideology. Policies and the ideologies that support them evolve with the political fortunes of such groups. Antitrust policy is not an exception. While advances in economic theory and policy experience over time do influence antitrust, larger policy paradigm shifts are responsible for the major disjunctions in antitrust theory and enforcement.

Antitrust policy is part of a subset of policies (e.g., corporate law, labor legislation, and regulatory law) focused on the perceived negative consequences attendant to the rise, expansion and dominance of big business. The hunt for ever-higher profits by big business has yielded significant economic progress, but has also often spawned anticompetitive behavior, harm to the other classes in society, including labor and small business, and created macroeconomic instability. ${ }^{2}$ These forms of harm, as Joseph Schumpeter observed, can result in suboptimal economic performance and the impairment of democratic institutions. ${ }^{3}$ For example, when big business prevents real wages from increasing it can erode economic incentives to innovate. ${ }^{4}$

\footnotetext{
${ }^{2}$ For an economic model and evidence on this point, see Gérard Duménil and Dominique Levy, The Economics of the Profit Rate, Elgar (1993) at Chapters 11 and 12; Gérard Duménil and Dominique Levy, "Profitability and Stability" in D. B. Papadimitriou, Profits, Deficits and Stability, Macmillan (1992).

${ }^{3}$ Joseph Schumpeter, Capitalism, Socialism and Democracy, Harper (1950) at 76 ("But between realizing that hunting for a maximum of profit and striving for maximum productive performance are not necessarily compatible...").

${ }^{4}$ Economists as diverse as John Hicks and Karl Marx have recognized the notion that high wages create incentives to innovate. John Hick, The Theory of Wages, Macmillan (1932) at 124-125; Karl Marx, Capital Vol I, Progress (1971) Chapter 15, Section 3. See e.g., H.J. Habakkuk, American and British Technology in the Nineteenth Century: Search for Labor Saving Inventions, Cambridge (1962); Robert Allen, Global Economic History: A Short
} 
Antitrust has traditionally sought to protect and enhance the competitive process as its policy tool to address such issues.

The first section of this paper identifies six epochs in the economic history of the United States, reflecting the milestones and transition periods in the development of antitrust law. ${ }^{5}$ To be clear, this paper does not purport to fully address the economic history of these eras. Its principle objective is to show that over these six economic epochs, there were three major policy regimes each reflecting quite distinct antitrust approaches. Up to the Great Depression, policy in the United States was broadly associated with laissez-faire consisting of an unmanaged economy and adherence to the gold standard. Although several new antitrust statutes emerged under this policy regime, there was minimal antitrust enforcement. This changed dramatically after the Great Depression. In the later part of the New Deal a new policy consensus emerged that included strong regulation of finance, income equalization, high wages, support for unions, and strong antitrust enforcement. As detailed below, this new policy regime coincides with the greatest period of economic growth and prosperity in U.S. history. During the crisis of the 1970s neoliberalism rose to policy prominence. This new policy regime expressed confidence that the unfettered actions of big business would result in positive economic outcomes for everyone. The Chicago School of antitrust is an integral part of the neoliberal policy program. This policy

Introduction, Oxford (2011) at 33. Gérard Duménil and Dominique Levy, "A Stochastic Model of Technical Change, Applications to the U.S. Economy (1869-1985)," 46 Metroeconomica 213 (1995); Gérard Duménil and Dominique Levy, "Competing Factors in Inducement of Technical Progress," CEPREMAP Working Paper (1989); Robert Gordon, The Rise and Fall of American Growth: The U.S. Standard of Living since the Civil War, Princeton (2016) at 563; Lance Taylor and Ozlem Omer, "Race to the Bottom: Low Productivity, Market Power, and Lagging Wages," INET Working Paper No. 80, August 8, 2018 at 5. Additional references can be found in Vernon Ruttan, Is War Necessary for Economic Growth: Military Procurement and Technology Development, Oxford (2006) at 911.

${ }^{5}$ The dating of these economic epochs derive from an earlier paper, Gérard Duménil, Mark Glick and Dominique Levy, "The History of Economic Policy as Economic History," 62 Antitrust Bull. 373 (1997). I have made modifications to this earlier periodization in order to capture the changing antitrust policy approaches. See also Gérard Duménil and Dominique Levy, "Periodizing Capitalism: Technology, Institutions, and Relations of Production" in Robert Abbritton, Phases of Capitalist Development, Booms, Crises and Globalization, Palgrave (2001). 
regime has resulted in significantly inferior economic performance compared with the New Deal policy that it replaced.

\section{The Periodization of Antitrust History}

This section introduces the long-term data series of the rate of profit in the United States from 1869 to 2015 as a device to help illustrate the periodization of antitrust history. ${ }^{6}$ The periodization adopted here consists of six periods: The Gilded Age, the Progressive Era, the New Deal ${ }^{7}$, the Post World War II golden age of capitalism, ${ }^{8}$ the crisis of the 1970 s, and the age of neoliberalism which encompasses the present. ${ }^{9}$

\footnotetext{
${ }^{6}$ The data come from Gérard Duménil and Dominique Levy, "The historical trends of technology and distribution in the U.S. economy since 1869." Appendix I reproduces this data.

${ }^{7}$ I will also refer to the New Deal period as the "great leap forward" as used in Alex Field, A Great Leap Forward: 1930s Depression and U.S. Economic Growth, Yale (2011); and adopted by Robert Gordon, The Rise and Fall of American Growth: The U.S. Standard of Living Since the Civil War, Princeton (2016).

${ }^{8}$ I will refer to this period as simply the "golden age of capitalism," following Field and Gordon.

${ }^{9}$ The reason that I have chosen the rate of profit is because it reflects the most important measures of economic performance and itself is the goal of firm performance. The rate of profit is the ratio of firm profits (the numerator) and the stock of equipment and structures or the capital stock (the denominator). In the figure, profit variable is defined as Net National Product less total compensation; this yields a measure of total profit that includes interest and indirect taxes. The rate of profit can be divided into the share of profit, $\mathrm{p} / \mathrm{y}$, where " $\mathrm{y}$ " represents national income, and the capital to output ratio, $\mathrm{k} / \mathrm{y}$, which is a (inverse) measure of the productiveness of capital assets and a function of innovation. This can be seen from the following equation: $\frac{P}{K}=\frac{P}{Y} \times \frac{Y}{k}$. Over most of U.S. history (until the late 1970s) the profit share was roughly constant. The rate of profit tends to measure the dynamic efficiency of the U.S. economy. To be clear, we need to focus only on long run changes over say, a decade or more. This is because short-run changes over the business cycle influence output, the variable " $y$ ". The vertical axis on Figure 1 represents the percent rate of profit, and the horizontal axis are years.
} 


\section{Figure $1^{10}$}

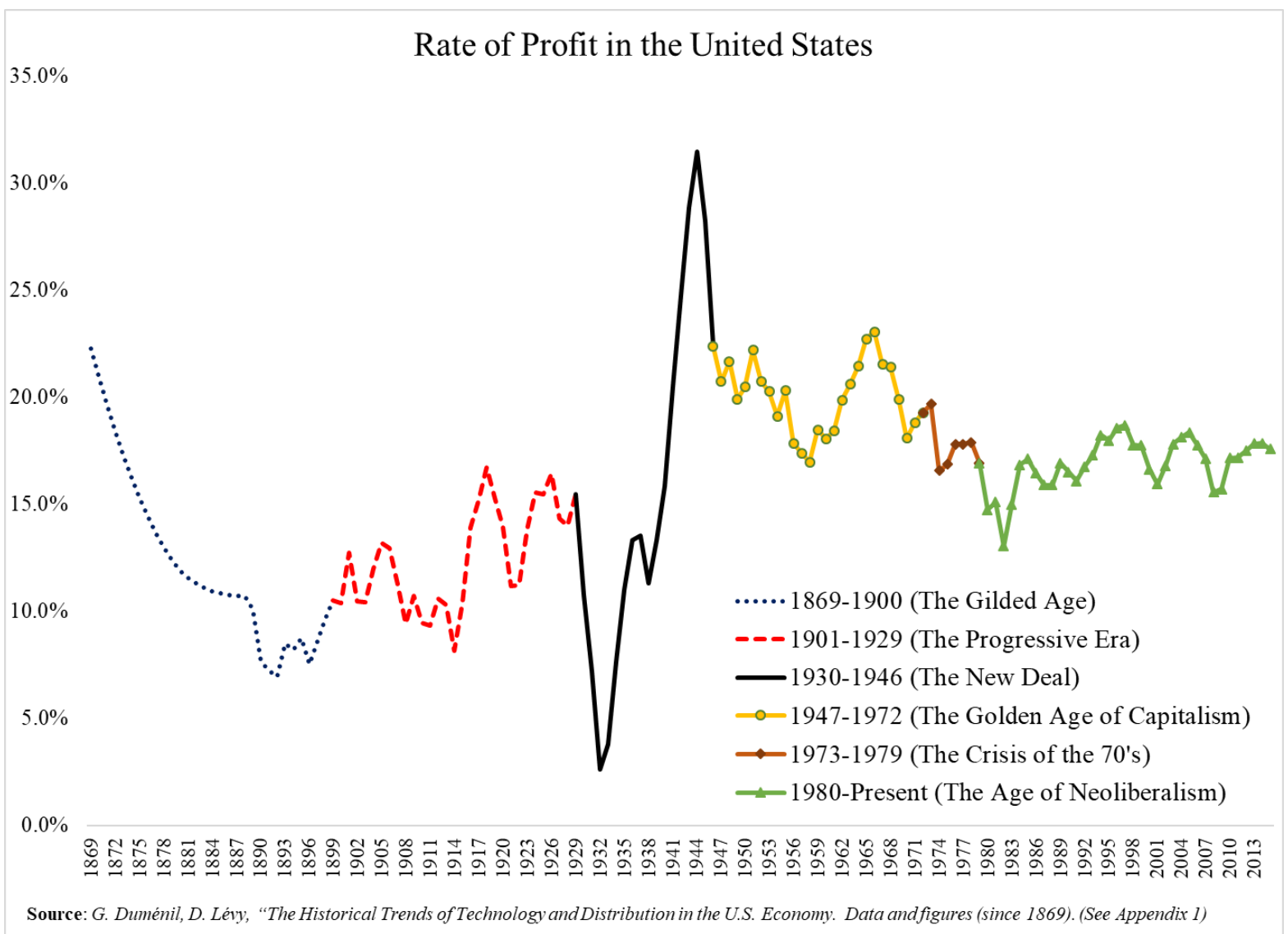

One can identify in Figure 1 the six major periods used in this paper. From 1869 to the turn of the $20^{\text {th }}$ century, there is a dramatic fall in profitability. It was the period of the emergence of big business, their struggle to contain "ruinous competition," the rise of the trusts, and the Sherman Act response. After 1900, the profit rate stabilizes, as the corporate and managerial revolutions unfold, along with the Progressive Era effort to revise and supplement the Sherman Antitrust Act. At the end of the 1920s, the Great Crash occurred, attributable in part to the instability that accompanied the rise of large, highly managed, and interconnected firms. At the bottom of the depression (1933), a new policy regime emerged with the New Deal, replacing the pre-Depression laissez-faire policy. The New Deal policy advocated strong antitrust

\footnotetext{
10 Source: Appendix I.
} 
enforcement, union power, and government driven economic management. Figure 1 further depicts an enormous advance in the rate of profit associated with the New Deal. It was truly a great leap forward for the economy. The continued implementation of New Deal policies extended the high profit rates into the period immediately following World War II, a prosperous era known as the golden age of capitalism. Figure 1 also shows the dramatic fall in profitability that occurred at the end of the 1960s and continued into the 1970s. This is the period referred to in this paper as the crisis of the 1970s. Subsequently, a new policy regime based on neoliberalism emerged with the Chicago School of antitrust as a central component. Far from advancing corporate efficiency and unleashing investment, neoliberalism has produced historically low profits, low growth, low productivity, and high-income inequality.

\section{The Gilded Age}

The Gilded Age is the period when big business first emerged in the United States. In response to concerns about its impact by other sectors of the economy, Congress enacted the Sherman Act of 1890, the first, and arguably the most significant, policy attempt to regulate the behavior of big business.

\section{a. Industrialization and the Managerial Revolution}

The industrial revolution in the United States gained its full stride after the U.S. Civil War. During the antebellum era, agriculture and small industrial enterprises dominated the economy. The small personally managed industrial firms relied on water for power and had few employees. $^{11}$ The lack of sufficient supplies of coal and labor shortages delayed U.S. industrialization compared to Great Britain. $^{12}$

\footnotetext{
${ }^{11}$ Alfred Chandler, The Visible Hand: The Managerial Revolution in American Business, Harvard (1977) at 48, 61.

${ }^{12} I d$. at 50,76 .
} 
Immigration following the 1848 revolutions in Europe and the opening of the anthracite coalmines in eastern Pennsylvania lifted the constraints on industrialization. ${ }^{13}$ The modern business enterprise in the U.S. then emerged with the advent of the railroads, which were by far the largest and most dynamic industry of the early industrial revolution. The railroads represented a joint effort by local governments and private interests ${ }^{14}$ and adopted the corporate form. The early railroads were formed as corporations because they followed the example of the quasi-public canal companies, which were also corporations. ${ }^{15}$

Alfred Chandler described the technical problems involved in the operation of the railroads. The difficulties included coordination of tracking rights, standardization of equipment and procedures, and efforts to control competition. These challenges required skilled middle managers who "were responsible for devising and perfecting a number of basic organizational and technological innovations so central to the efficient operation of the railroads." ${ }^{\text {16 }}$ The special requirements of railroad operations initiated the first managerial revolution in the United States. The demand for managers resulted in dramatic societal changes including engineering departments at leading universities, professional societies, and cultural transformations in American cities. ${ }^{17}$ The investment needs of the railroads further formed the basis for the development of other large businesses including steel, machinery, chemicals, refining and distilling, and others. The railroads created mass markets served by new large retail and wholesale firms such as Macy's, Lord \& Taylor, Bloomingdales, Marshall Field's and other

\footnotetext{
${ }^{13} I d$.

${ }^{14}$ William Roy, Socializing Capital: The Rise of the Large Industrial Corporation in America, Princeton (1997) at 83. David Kotz, The Rise and Fall of Neoliberal Capitalism, Harvard (2017) at 183.

${ }^{15} I d$. at 267.

${ }^{16}$ Alfred Chandler, The Visible Hand: The Managerial Revolution in American Business, Harvard (1977) at 143.

${ }^{17} I d$. at 132.
} 
large retailers. ${ }^{18}$ In turn, the mass market made large-scale production in consumer goods and other products feasible.

There is a common misconception that the Gilded Age was an era of free trade. On the contrary, industrialization in the United States in the $19^{\text {th }}$ century occurred under the protection of a high tariff. The U.S. tariff on manufactured products ranged from 40-50\% between 1875 and 1913. ${ }^{19}$ Despite such protectionist policies, a global trade revival flourished between 1870 and 1913. While this increased commerce resulted from new technologies such as the telegraph as well as refrigeration, it consisted primarily of trade in agricultural products. ${ }^{20}$

\section{b. $\quad$ Big Business, Bertrand Competition and Collusive Practices}

The railroads and developments in communications helped break down local barriers to competition. $^{21}$ As a consequence, the new large firms faced fierce price competition from their peers. We now understand this phenomenon as Bertrand competition with homogeneous products, but it was called "ruinous competition" at the time. ${ }^{22}$ Another consequence was nominal price deflation, which also characterized this period. The wholesale price index in 1890 was $39.2 \%$ below its level in $1870 .^{23}$ Figure 1 evidences a spectacular decline in average

\footnotetext{
${ }^{18} I d$. at $224-235$.

${ }^{19}$ Ha-Joon Chang, Kicking Away the Ladder: Development Strategy in Historical Perspective, Anthem (2003) at 7; Ian Fletcher, Free Trade Doesn't Work: Why America Needs a Tariff, U.S. Business \& Industry Council (2009) at 139 (presenting data on the size of the U.S. Tariff as a percentage of total imports from 1820 to 2000).

${ }^{20}$ Thomas I. Palley, "Three Globalizations, not Two: Rethinking the History and Economics of Trade and Globalization," FMM working Paper, March, 2018 at 3-4; Dani Rodrik, The Globalization Paradox: Democracy and the Future of the World Economy, Norton (2011) at 25.

${ }^{21}$ Hans Thorelli, The Federal Antitrust Policy: Origination of an American Tradition, Johns Hopkins (1955) at 67 ("On the other hand the rigors of competition were often cushioned by the limitations of the nation's transportation system, allowing local businessmen a certain amount of monopoly power."). The telegraph and advances in communications also played an important role.

${ }^{22}$ Naomi Lamoreaux develops the theory and the evidence for $19^{\text {th }}$ century ruinous competition in her book, The Great Merger Movement in American Business 1895-1904, Cambridge (1985). Lamoreaux argues that this process was only ultimately curtailed by the first merger movement and vertical integration, which created barriers to entry. However, the rise of marketing and advertising further differentiated firm output.

${ }^{23}$ David Kotz, The Rise and Fall of Neoliberal Capitalism, Harvard (2017) at 183.
} 
profitability beginning in 1869 and continuing until the end of the 1890 recession at the turn of the century. The profit rate decline created serious macroeconomic instability. A deep recession resulted in $1873,{ }^{24}$ followed by subsequent recessions in 1876,1889 and again in $1892 .^{25}$ Originally, this period was called the "Great Depression" before the term was appropriated and attached to the depression that began in 1929. Michael Roberts is one of a handful of economists to assemble the economic evidence from this period:

Evidence for a depression in the United States is most dramatically seen in railroad construction, where the financial panic of 1873 was located... Railroad construction began to recover after 1875, but it did so fitfully and basically remained flat and low during the 1876-78 period, fluctuating around 3,000 miles of construction. Only in 1879 did construction surge again up to 5,000 miles, followed by the biggest surge of all as the 1880 s proved to be by far the leading decade of rail construction, followed by a nearly total collapse in the $1890 \mathrm{~s}^{26}$

The new large enterprises responded to the strong competitive forces by forming pools and cartels with various degrees of central direction and inter-firm integration of decisionmaking. ${ }^{27}$ Hans Thorelli reported that large numbers of such cartels formed in the Gilded Age

\footnotetext{
${ }^{24}$ These were difficult periods for large sections of the American population. "During the first three months of 1874 about 90,000 homeless workers, two-fifths of whom were women, were lodgers in New York City's police station houses. They were called 'revolvers' because they were not permitted to spend more than one or two days a month in any one station-house. They slept huddled together in their damp clothes on hard benches, and were turned out hungry at daybreak...But the well-housed and well-fed condemned the 'the over-generous charity of the city' in providing even the hard benches because it 'might sap the foundation of that independent of character, and that reliance on one's own resources." Philip Foner, "History of the Labor Movement in the United States, Vol. 1, Int. (1947) at 442.

25 "Eighteen hundred and ninety-two was the year of some of the most bitter class conflict in American labor history." Philip Foner, "History of the Labor Movement in the United States, Vol. 2, Int. (1947) at 206.

${ }^{26}$ Michael Roberts, The Long Depression: How it Happened, Why it Happened, and What Happens Next, Haymarket (2016) at 36.

${ }^{27}$ The U.S. Industrial Commission reported in 1900 that "Among the causes which have led to the formation of industrial combinations, most of the witnesses were of the opinion that competition, so vigorous that profits of nearly all competing establishments were destroyed, is to be given first place." Quoted in Martin Sklar, The Corporate Reconstruction of American Capitalism 1890-1916, Cambridge (1988) at 56. The U.S. Industrial Commission was formed in June 1898 and operated for three years.
} 
including hundreds of tight combinations (generally referred to as "trusts, ${ }^{28}$ ) that strongly restricted independent action. ${ }^{29}$

\section{c. The Sherman Act}

The actions of the trusts fostered significant public hostility. As Thorelli summarized, "it would seem that public concern, as conditioned by developments in the economic, social, constitutional and political fields, at the end of the 1880s had become serious enough to make federal action against the trusts a clear desideratum, if not an absolute necessity." 30 The increased prices resulting from these trusts and pools had serious consequences for agriculture, urban workers, and small businesses. During the Gilded Age, these groups possessed significant political power that could potentially influence policy. ${ }^{31}$ Political pressure mounted until legislative action was unavoidable, and on August 14, 1888, John Sherman introduced the first antitrust bill, which resulted in the eponymous act of 1890. The Senate debated the Sherman bill for 18 months without reaching any consensus on language or scope. Then, on March 27, 1890, the bill was referred to the judiciary committee. ${ }^{32}$ Within a week, on April 2, 1890, the committee reported out a completely redrafted bill, largely the work of George Edmunds of Vermont. The bill passed the full Senate on April 8, 1890. The vote was nearly unanimous with only one dissenter.

What explains the extended two-year deadlock followed by the swift agreement? At the state level during that time, the political power of big business and the other economic classes

\footnotetext{
${ }^{28}$ Hans Thorelli, The Federal Antitrust Policy: Origination of an American Tradition, Johns Hopkins (1955) at 161.

${ }^{29}$ Id. at $73,285-305$.

${ }^{30} I d$. at 163 .

${ }^{31}$ Antitrust was the centerpiece of the Union Labor Party, a coalition of Greenbackers, Knights of Labor and farmer organizations. Both the Democratic Republican parties passed antitrust statements. William Letwin, Law and Economic Policy in America: The Evolution of the Sherman Antitrust Act, Chicago (1965) at 85-86.

${ }^{32}$ It had previously been assigned to the finance committee.
} 
including agriculture, small business and to a lesser degree labor were roughly comparable. ${ }^{33}$ Big business was politically powerful, but so was agriculture and small business. The rhetoric of the Congressional debates reflects these contending class interests. Supporters of big business stressed the concept of freedom of contract, the right of business to enter into contracts of their choosing. Such freedom, they contended, included the right to enter into contracts with competitors or to buy and sell business property without restriction. Supporters of agriculture, labor and small business adopted a narrative of free competition and the important role of government in protecting the competitive process. ${ }^{34}$

The compromise bill by Senator Edmunds was sufficiently ambiguous that both sides could read it as supportive of their own position. This ambiguity is evident from the opening line of Section 1 of the Sherman Act that states, "Every contract, combination in the form of trust or otherwise, or conspiracy, in restraint of trade or commerce among the several States...is declared to be illegal." The use of the word "all" coupled with the term "restraint of trade" which in the common law referred to only unreasonable restraints of trade sapped the Sherman Act of any plain meaning. The resulting semantic ambiguity implied "all" restraints, and "not all" restraints

\footnotetext{
33 "The total results of the [1892] election must have startled both old parties. Though Cleveland was elected, Weaver polled over a million votes and received 22 electoral votes. It was the first third party to break into the electoral college since the Civil War. In addition, the People's Party sent ten Representatives and five Senators to Congress..." Philip Foner, History of the Labor Movement in the United States Vol 2, Int. (1947) at 309.

${ }^{34}$ These two positions are explained in great detail by Rudolph Peritz in his book Competition Policy in America 1888-1992: History, Rhetoric, Law, Oxford (1996). For example Peritz wrote that, "Floor debate was divided into two rhetorical camps, the same division that produced the split vote referring Sherman's bill to Edmund's Judiciary Committee. Sherman and other supporters of the original bill's language of "full and free competition" maintained that industrial combinations, whether trusts or cartels, were antithetical to "the industrial liberty of citizens." In the opposing camp were those who believed that competition could be as dangerous as combination. They maintained that private agreements to mitigate the effects of "ruinous competition," to assure the producer a "fair price," were reasonable." Id. at 14. Martin Sklar described the debate this way: "The drafting of the Sherman Antitrust Act (1889-1990) and its subsequent early enforcement and judicial construction (1890-1911) became a critical field of contest among advocates of small-producer, proprietary-capitalist property and corporate-capitalist property, and correspondingly between those favoring a regulated market suited to preserving and strengthening proprietary capitalism and those favoring a market suited to encouraging, protecting, and legitimizing corporate capitalism." Martin Sklar, The Corporate Reconstruction of American Capitalism 1890-1916, Cambridge (1988) at 89-90.
} 
were within the purview of the Act at the same time. Therefore, decades of judicial interpretation would be required before the Supreme Court would settle on a clear and consistent meaning in the Standard Oil case in 1911.

\section{d. Early Sherman Act Enforcement}

Once President Harrison signed the Sherman Act into law the onus of enforcement passed to the executive branch, and in particular, to the attorney generals. Unlike the states, big business interests dominated the executive administrations during the Gilded Age, and consequently attorney generals initiated few antitrust cases. ${ }^{35}$ During the thirty-two months of the Harrison administration, for example, it brought only seven cases. ${ }^{36}$ The Cleveland administration brought eight cases, four of which were against labor. ${ }^{37}$ The McKinley administration filed only three antitrust suits. Indeed, the only individual to go to jail in the first few decades of Sherman Act enforcement was Eugene Debs, a labor leader and member of the socialist party.

Once cases began to reach the Supreme Court in the Gilded Age, the Court had to struggle with several difficult issues. For example, the Court had to reconcile the prevailing narrow definition of interstate commerce with antitrust enforcement against national firms. For example, it dismissed the challenge to an acquisition by American Sugar Refining that would

\footnotetext{
${ }^{35}$ Richard Baker, Carola Frydman, and Eric Hilt, "Political Discretion and Antitrust Policy, Evidence from the Assassination of President McKinley," NBER (Nov. 17, 2018) (showing the McKinley assassination and the succession of Theodore Roosevelt resulted in greater stock declines in firms vulnerable to antitrust scrutiny).

${ }^{36}$ Hans Thorelli, The Federal Antitrust Policy: Origination of an American Tradition, Johns Hopkins (1955) at 376.

${ }^{37}$ Id. at 384. One of Cleveland's Attorneys Generals, Richard Olney, was notoriously pro-business and anti-labor. He brought all four labor cases including the Debs case, brought no business antitrust cases, and dropped one of the important cases brought by the Cleveland administration. Id. at 389. According to William Forbath, "By a conservative reckoning, at least 4,300 injunctions were issued between 1880 and 1930 . These amounted to only a small fraction of the total number of strikes for most of those five decades, although by the 1920s the fraction had increased to 25 percent. The proportion of large secondary actions enjoined, however, was substantial throughout this period. In the 1890s, the decade that saw the greatest number of sympathy strikes in the country's history, courts enjoined at least 15 percent of recorded sympathy strikes." William Forbath, Law and the Shaping of the American Labor Movement, Harvard (1989) at 61-62.
} 
have resulted in a ninety-eight percent market share because the acquired assets were located in a different state than the acquirer. ${ }^{38}$ Curiously, the Court had fewer problems upholding the applicability of the Sherman Act to labor activity in In re Debs, even though the legislative history of the Sherman Act indicated Congressional intent to exclude labor from Sherman Act scrutiny. ${ }^{39}$ Of great significance was the Court's decision in United States v. Trans-Missouri Freight, 166 U.S. 290 (1897), that interpreted Section I of the Sherman Act to apply to all restraints of trade whether reasonable or not. ${ }^{40}$ This decision would mobilize big business to organize to revise the Sherman Act and seek further supplementary antitrust legislation during the Progressive Era.

\section{The Progressive Era}

Antitrust policy was center stage during the Progressive Era. The passage of the Sherman Act did not quell the political opposition by the other classes to unfettered action by big business. The Progressive Era was also the period in which the corporate revolution replaced the robber barons with professional managers at the top levels of the large industrial firms. The rising strength of big business inspired commensurate public disapproval. The new large corporations sought revisions to antitrust and corporate law in an effort to alleviate the very real threat of more radical regulation being advanced by the popular classes and their representatives.

\footnotetext{
38 156 U.S. 1 (1895).

${ }^{39} 158$ U.S. 564 (1895). For a discussion of the Congressional debates on this issue see Elinor Hoffman, "Labor and Antitrust Policy: Drawing a Line of Demarcation," 50 Brook. L. Rev. 1, 15-19 (1983). See also, Robert Lande and Richard Zerbe, “Anticonsumer Effects of Union Mergers: An Antitrust Solution,” 46 Duke L.J. 197, 201 (1996); Herbert Hovenkamp, “Labor Conspiracies in American Law 1880 - 1930,” 66 Tex. L. Rev. 919 (1988).

${ }^{40}$ Following his opinion in Trans-Missouri Freight, Judge Peckham struck down a Louisiana law requiring the purchase of insurance on substantive due process grounds or "liberty of contract." Interestingly, in the next major antitrust case, United States v. Joint Traffic Association, 171 U.S. 505 (1898), the defense argued that the circuit court decision in favor of the government deprived defendants of their substantive due process right to liberty of contract. Judge Peckham writing for the court, held that freedom of contract under the $14^{\text {th }}$ Amendment protects only lawful contracts. This answer begs the question to some extent because the underlying issue is whether every contract in restraint of trade is unlawful in the first place.
} 
Political stability thus required new legislation. This process resulted in the Clayton Act and the Federal Trade Commission Act, both passed in 1914. Little change in antitrust enforcement activities followed in their aftermath. Big business continued to grow and advance apace, under a continued regime of laissez-faire unregulated capitalism.

\section{a. The Corporate Revolution and the Rise of Finance}

The giant industrial corporations were in many ways a product of the first great merger wave of 1887 to 1904 . With the exception of the railroads, the early large American industrial enterprises were partnerships. The Gilded Age managerial revolution was limited to the middle levels of these partnerships, while owners maintained control at the top. The merger movement altered this structure through the formation of corporations. The corporate form required the replacement of the owners at the top levels of management with boards of directors. These boards were normally comprised of professional managers and banking interests. The merger movement also created the modern financial markets that arose to finance these acquisitions through the sale of securities to the public.

\section{The Early Merger Process}

The process of combining smaller competing industrial enterprises into the giant corporations could not have occurred without important revisions to the corporate law. As Lawrence Mitchell detailed, the merger movement transformed the role of bankers such as J.P. Morgan, John Gates, and Charles Flint. ${ }^{41}$ The process that developed was for the leading acquiring enterprise to use its own stock to purchase an array of smaller competing firms. However, these types of transactions necessitated the reversal of existing prohibitions on

\footnotetext{
${ }^{41}$ Lawrence Mitchell, The Speculative Economy: How Finance Triumphed Over Industry, Berrett-Koehler (2007) at 57-58. William Lazonick, "The Functions of the Stock Market and the Fallacies of Shareholder Value," INET working paper, June 3, 2017 at 6 ("Central to the process of separating share ownership and managerial control in the rise of big business in the United States was the Great Merger Movement of the 1890s and early 1900s.”).
} 
corporate purchases using shares and the corporate rules against holding companies. Through intense lobbying efforts, state legislatures began to revise these traditional corporate principles. New Jersey was the first state to reverse prior precedent and allow purchases of other companies with stock. ${ }^{42}$ This raised the further legal issue of how the purchased corporate property should be valued. Again, New Jersey led the way by allowing the good faith judgment of the directors to be determinative, cutting off liability to corporate stakeholders for mistaken valuations. The revised law allowed directors to affix high values on purchased assets, which also justified large amounts of issued stock. ${ }^{43}$ Other states quickly followed New Jersey’s lead.

Wall Street promoters typically compensated the original industrial owners with bonds or sometimes preferred shares. The owners of the acquired entity would usually receive a combination of preferred and common shares in return for the sale of their firms. These sellers were usually savvy enough to require that the value of the preferred shares equal their own internal valuation of their company, plus they demanded additional common shares. The purchasing company was sometimes further required to limit their issuance of preferred shares to amounts equal to the value of their hard assets. The size of the issuance of common shares had to be justified by some measure of "good will," but this generally involved significant speculation. The promoters received common shares as payment, which created an incentive to sell the common share subscriptions to the public. William Lazonick offered a compact summary of this process:

Here is how it worked. Wall Street investment banks - J.P. Morgan foremost among them - underwrote the merger of a group of firms in an industry to create a business entity with a large market share that could be floated on the NYSE. The underwriting

\footnotetext{
${ }^{42}$ Lawrence Mitchell, The Speculative Economy: How Finance Triumphed Over Industry, Berrett-Koehler (2007) at 42 ("This development was perfected in 1896, the year before the merger wave began").

${ }^{43} I d$. at 45-48. This was the origin of "watered stock".
} 
syndicate issued corporate bonds to pay the owner-entrepreneurs and their private equity partners for their ownership stakes, and then sold the listed shares to the public over time as the syndicate saw fit. The result was the transfer of ownership of corporate assets from the original owner-entrepreneurs to an increasingly widely distributed population of shareholders. ${ }^{44}$

Thus, the merger process simultaneously created the modern stock market and a core set of giant corporations. Thereafter, the corporation became the legal form of choice and corporations quickly proliferated. As James Weinstein described:

In eight years from 1897 to 1904 , corporations with assets totally $\$ 6,000,000,000$ were organized, compared to a total of about $\$ 1,000,000,000$ in the years between 1879 and 1897. By 1904 the top four percent of American concerns (the great majority of which were corporate in form) produced 57 percent of the total industrial output by value. By any standard of measurement, large corporations had come to dominate the American economy by $1904 .^{45}$

\section{The Merger Movement and Top Management}

The corporate revolution accelerated the managerial revolution by placing professional managers in charge of the most important decision making functions of the firm. As Alfred Chandler wrote, "[ $\mathrm{t}] \mathrm{he}$ practices and procedures of modern top management had their beginnings in the industrial enterprises formed by merger."46 These new, top-level managers, introduced for the first time, cost accounting, scientific management ("Taylorism"), public relations, market intelligence, interdivision coordination, and other measures. ${ }^{47}$ This extension of the managerial revolution was fundamental to the ability of the large corporation to exploit the major scientific

\footnotetext{
${ }^{44}$ William Lazonick, "The functions of the Stock Market and the Fallacies of Shareholder Value," INET working paper, June 3, 2017 at 6.

${ }^{45}$ James Weinstein, The Corporate Ideal in the Liberal State 1900-1918, Beacon (1968) at 63. Martin Sklar points out that " $[\mathrm{m}]$ any proprietary capitalists themselves changed their business organization to the corporate form, while many others were quick to join in the advantages of corporate reorganization initiated by larger capitalists, promoters, or financiers." Martin Sklar, The Corporate Reconstruction of American Capitalism 1890-1916, Cambridge (1988) at 29.

${ }^{46}$ Alfred Chandler, The Visible Hand: The Managerial Revolution in American Business, Harvard (1977) at 415.

${ }^{47}$ Id. at Chapter 13. Chris Freeman and Luc Soete, The Economics of Industrial Innovation, MIT (1997) at 81-82.
} 
breakthroughs in electrification, advances in the internal combustion engine, steel alloys, furnace technologies and other technologies created earlier or during the Progressive Era. ${ }^{48}$ The impact of these events are evident from figure 1 which depicts a slow increase in the rate of profit at the turn of the century (after the Gilded Age decline), and then another advance in the period following the recession of 1921. However, the managerial revolution also had negative consequences. Under tight management control, big business gained more leverage over their employees and could more effectively monitor and limit their freedom of action. In addition, the corporate ability to react quickly and decisively to economic changes in its environment further yielded recessionary dangers. ${ }^{49}$

\section{The Merger Movement and Financial Control}

The processes that led to the giant corporations also initiated a process of financialization in the U.S. economy. ${ }^{50}$ The bankers that had facilitated the merger process took board seats and sought to "obtain substantial, if not total, managerial control." 51 The Morgan partners alone held

\footnotetext{
${ }^{48}$ In his book Capitalism, Socialism and Democracy, Joseph Schumpeter interpreted this managerial revolution as the beginning of the decline of capitalism. Joseph Schumpeter, Capitalism, Socialism and Democracy, Harper and Row (1942) at 156 ("We have seen that, normally, the modern businessman, whether entrepreneur or mere managing administrator, is of the executive type. From the logic of his position, he acquires something of the psychology of the salaried employee working in a bureaucratic organization. Whether a stock holder or not, his will to fight and to hold on is not and cannot be what it was with the man who knew ownership and its responsibilities in the full-blooded sense of these words...Thus the modern corporation, although the product of the capitalist process, socializes the bourgeois mind; it relentlessly narrows the scope of capitalist motivation; not only that, it will eventually kill its roots").

${ }^{49}$ See references in Footnote 2. See also, Gérard Duménil, Mark Glick and Jose Rangel, "Theories of the Great Depression: Why Did Profitability Matter?" 19 Rev. of Rad. Econ. 16, 33 (1987).

${ }^{50}$ Financialization refers to the dominance of capital market financial systems over bank based financial systems and the increasing political and economic power of financial corporations over non-financial corporations. See Gerald Epstein, Financialization and the World Economy, Elgar (2005).

${ }^{51}$ Gabriel Kolko, The Triumph of Conservatism: A Reinterpretation of American History, 1900-1916, Free Press (1963) at 23 ("Morgan's efforts were generally marked by success."); William Roy, Socializing Capital: The Rise of the Large Industrial Corporation in America, Princeton (1997) at 198 ("Manufacturers, tempted by the prospect of Morgan's millions, made their Faustian bargain. Industrial capital merged with investment capital and sparked the corporate revolution."). Control by finance was never complete.
} 
167 directorships in eighty-nine corporations with assets over $\$ 20$ billion. ${ }^{52}$ Bankers focused on protecting the value of corporate securities on the stock market both because banks owned large blocks of these securities and because they needed to protect their reputations with their clients who purchased bonds or stocks. Because of this self-interest, the financial sector board members advocated for high and regular dividend payments and the prompt payment of interest on corporate bonds. The financial sector's increasing power made securities markets central for obtaining investment financings, and this structure eventually contributed to the advent of the Great Depression.

\section{4. $\quad$ Antitrust Policy in the Progressive Era}

Antitrust debates took center stage in the Progressive Era. This was not solely because of narrow concerns about the ability of the new corporations to raise prices, but also because of the numerous ways that the managerial and the corporate revolutions disadvantaged the other classes in society. The proposed antitrust legislation in the Progressive Era included issues of financial disclosure, watered stock, destruction of small businesses, and labor's rights within the new large enterprises. During the Progressive Era, the other traditional classes and groups, farmers, workers and small businesses, continued to possess significant political power, particularly at the state level. The majority of the population remained small agricultural proprietors, and "populism, representing powerful strands of the small-producer outlook, was the principal political antagonist of the corporate capitalist movement." ${ }^{, 53}$ The American Federation of Labor

\footnotetext{
52 Michael Hiltzik, The New Deal: A Modern History, Free Press (2011) at 82.

${ }^{53}$ Martin Sklar, The Corporate Reconstruction of American Capitalism 1890-1916, Cambridge (1988) at 77. Sklar further stated that "market relations, forms of thought, political movements, and cultural patterns associated with small producer and proprietary enterprise remained widespread, influential and strongly represented in party politics, Congress, and the judiciary, and at the state and local levels of politics and government. They continued to exert a large impact, moreover, in the national electoral arena and in national legislative forums. The large corporations and corporate-administrated markets, for some time to come, lacked anything near full legitimacy in the minds of a considerable segment of the people and their political representatives." Id. at 15.
} 
("AFL) grew in number and achieved some political successes at the state level. ${ }^{54}$ The Socialist Party of America grew continuously until 1912 and "exerted a wide impact upon the political life of the nation." ${ }^{55}$ By 1912, the Socialists had 1,200 elected public officials and published over 300 periodicals. ${ }^{56}$ The transformations that occurred in the American economy touched all of these groups, and they feared the dilution of their political power, and the destruction of their economic viability. ${ }^{57}$ As Gabriel Kolko explained:

Big businessmen feared democracy, especially on the local and state levels where the masses might truly exercise their will, and they successfully turned to the federal government for protection. This fear was articulated, often quite frankly. ${ }^{58}$

With the backing of big business, Congress unleashed a wave of corporate reform measures between 1900 and 1914. "No fewer than sixty-two unsuccessful bills embraced federal incorporation or federal licensing. An additional eight attacked overcapitalization and seven more tried to create some form of securities regulation...Antitrust concerns remained central. But the growing congressional understanding that the "corporations" problem was bigger than

\footnotetext{
${ }^{54}$ William Forbath, Law and the Shaping of the American Labor Movement, Harvard (1989) at 21("In the early years of the century...the American labor movement claimed 20-25 percent of industrial workers").

55 James Weinstein, The Decline of Socialism in America 1912-1925, Vintage (1969) at 27.

${ }^{56}$ Id. Roosevelt wrote that the "growth of the Socialist party in this country [was] far more ominous than any populist movement in times past." Quoted in James Weinstein, The Corporate Ideal in the Liberal State 1900-1918, Beacon (1968) at 17. However, as Philip Foner notes, the Socialist Party was also split on the issue of monopoly. Some socialist took the position that monopoly was an essential step toward socialism. Philip Foner, History of the Labor Movement in the United States Vol 2, Int. (1947) at 380.

57 "The antitrust debates, then, were about basics: Were the central principles of the American political tradition compatible with anything other than small-producer, competitive capitalism? In particular, could they be reconciled with corporate capitalism and administered markets? If large-scale industry in the form of corporate enterprise was the progressive outcome of socioeconomic evolution, were traditional American political principles compatible with progress?" Martin Sklar, The Corporate Reconstruction of American Capitalism 1890-1916, Cambridge (1988) at 34.

${ }^{58}$ Gabriel Kolko, The Triumph of Conservatism: A Reinterpretation of American History, 1900-1916, Free Press (1963) at 161.
} 
monopoly alone led federal incorporation or licensing proposals to become the most frequently introduced type of antitrust legislation."

The history of antitrust in the Progressive Era distills to the effort by big business, with the support of sympathetic social reformers, academics and others, to establish "reasonable" federal regulation that could insulate big business from the political dangers posed by the Grangers, Populists, trade unionists and the socialists. All three Progressive Era presidents prior to World War I pursued antitrust reforms in the interest of social cohesion but without compromising the core interests of big business. The legislative efforts of the three presidents differed in details, but each remained faithful to the laissez-faire policy approach that served the overall interests of big business.

\section{The Theodore Roosevelt Administration}

Roosevelt viewed the large corporation as the natural result of modern economic progress. ${ }^{60}$ His strategy was to bring large corporations under limited administrative regulation, thereby saving capitalism, in his words, from "revolutionary chaos."61 Roosevelt's primary initiative was the 1903 Bureau of Corporations. He empowered the Bureau to investigate corporations, present their findings to the president (i.e., Roosevelt), and to publish its findings as he directed. The Bureau operated from 1903 until it became part of the Federal Trade Commission in 1914. Interestingly, the first report to the president in 1904 was highly critical of many corporate practices beyond monopoly pricing. The Bureau identified its primary antitrust

\footnotetext{
${ }^{59}$ Lawrence Mitchell, The Speculation Economy: How Finance Triumphed Over Industry, Berrett Koehler (2007) at 136.

${ }^{60}$ Roosevelt was also not much of a trust buster. "Roosevelt filed only three antitrust suits in 1902, two in 1903, and one in 1904." Gabriel Kolko, The Triumph of Conservatism: A Reinterpretation of American History, 1900-1916. Free Press (1962) at 74.

${ }^{61}$ Gabriel Kolko, The Triumph of Conservatism: A Reinterpretation of American History, 1900-1916. Free Press (1962) at 160. See also Id. at 76.
} 
concerns as "secrecy and dishonesty in promotion, overcapitalization, unfair discrimination by means of transportation and other rebates, unfair and predatory competition, secrecy of corporate administration, and misleading or dishonest financial statements. ${ }^{262}$ It further expressed concern about how industry had come under the excessive control of finance. ${ }^{63}$

In March 1908, while Roosevelt was still President, Congress introduced the Hepburn bill, drafted by The National Civic Federation. The National Civic Federation was the primary organization that represented the political interests of big business at the time. ${ }^{64}$ The Hepburn bill proposed a licensing scheme in which businesses could register and disclose essential business and financial information to the government. In return for registration, the government would prescreen prospective contracts. If an agreement was not found to constitute an "unreasonable restraint of trade" within thirty days, the government would then forfeit its right to bring an antitrust suit. Further, the bill prohibited private suits against registered corporations, and it granted labor an exemption from the Sherman Act (a provision added to gain the support of the American Federation of Labor). ${ }^{65}$ Opposition from the National Association of Manufacturers (NAM) was the primary reason for its defeat. ${ }^{66}$ Both NAM and Roosevelt

\footnotetext{
${ }^{62}$ Lawrence Mitchell, The Speculation Economy: How Finance Triumphed Over Industry, Berrett Koehler (2007) at 162 .

${ }^{63}$ In response, Roosevelt recommended a never implemented license-registration system for big business.

${ }^{64}$ James Weinstein, The Corporate Ideal in the Liberal State 1900-1918, Beacon (1968) at 6 ("Before the First World War the Civic Federation was the most important single organization of the socially conscious big businessmen and their academic and political theorists."). Martin Sklar, The Corporate Reconstruction of American Capitalism 1890-1916, Cambridge (1988) at 16; Lawrence Mitchell, The Speculation Economy: How Finance Triumphed Over Industry, Berrett Koehler (2007) at 170.

${ }^{65}$ While the Hepburn Act was defeated it formed one of the bases for the Federal Trade Commission Act. James Weinstein, The Corporate Ideal in the Liberal State 1900-1918, Beacon (1968) at 24 ("The initial thrust came to nothing, but in its outline the Federations's bill was embodied in the Federal Trade Commission Act of 1914").

${ }^{66}$ NAM represented the interested of small business. Philip Burch, "The NAM as an Interest Group," 4 Pol \& Soc. 97 (1973) ("A look at the board of directors of the NAM from its inception up to the early 1930s reveals that the aforementioned historians were probably right in describing the association as dominated by small and mediumsized business firms during these early years").
} 
fiercely opposed the labor exemption in the Hepburn Bill. ${ }^{67}$ As a result, no significant changes to legal or administration control of big business occurred under Roosevelt. ${ }^{68}$

\title{
6. $\quad$ The Taft Administration
}

William Taft succeeded Roosevelt as President in 1909. Taft also supported the interests of the large corporations, and he also recognized the necessity of some regulatory constraints to prevent social unrest. Unlike Roosevelt, Taft had more confidence in the ability of the judiciary to provide these necessary regulatory controls. Taft advanced no new administrative remedies, but instead brought twice as many Sherman Act suits as had the Roosevelt administration. ${ }^{69}$

\section{Woodrow Wilson and Louis Brandeis}

Martin Sklar placed Woodrow Wilson's antitrust approach somewhere between the approaches of Roosevelt and Taft. ${ }^{70}$ Wilson, like Roosevelt and Taft, viewed the development of

\begin{abstract}
${ }^{67}$ Gabriel Kolko, The Triumph of Conservatism: A Reinterpretation of American History, 1900-1916. Free Press (1962) at 135. James Weinstein disagreed with this assessment. Weinstein contended that small business objected primarily to the ability of government to immunize practices by big business at a time prior to the Standard Oil opinion in 1911. James Weinstein, The Corporate Ideal in the Liberal State 1900-1918, Beacon (1968) at 80-81.

${ }^{68} \mathrm{Tim} \mathrm{Wu}$ argued that Roosevelt supported a system where "[a]ll commerce would be controlled by a small group of monopolists, who would be, in turn, controlled by government (or perhaps vice versa). Tim Wu, The Curse of Bigness: Antitrust in the New Gilded Age, Columbia (2018) at 76. Barry Lynn makes much of the distinction between Roosevelt's new nationalism and Wilson's new freedom. Martin Sklar argues that the true difference concerned the role of the state: "There was more than a Tweedledee-Tweedledum difference between Roosevelt's New Nationalism and Wilson's New Freedom, but it did not reside in significant disagreement over "regulated monopoly" versus "regulated competition," or over affirming the corporate reorganization of the market in general and the demise of the old competitive regime, in defining the role of the state, or its positive action, in legalizing and legitimizing the corporate order and guaranteeing that it serve the public interest." Martin Sklar, The Corporate Reconstruction of American Capitalism 1890-1916, Cambridge (1988) at 420. Gabriel Kolko, The Triumph of Conservatism: A Reinterpretation of American History, 1900-1916, Free Press (1962) at 210 ("How does one distinguish the New Freedom from Roosevelt's New Nationalism? Practically, one cannot; but, for obvious political reasons, Wilson was compelled to distinguish his view from that of Roosevelt's ignoring his statement on their common beliefs in January 1912. The Progressive Party, he declared, accepted monopoly and proposed making bad trusts good by utilizing an executive commission. Wilson, in fact, was not opposed to a commission, and since 1908 had favored one based on a 'uniform process acting under precise terms of power in the enforcement of precise terms of regulation." ').
\end{abstract}

${ }^{69}$ Martin Sklar, The Corporate Reconstruction of American Capitalism 1890-1916, Cambridge (1988) at 376. Skylar explains that the cases brought by Taft were also more substantive and against major large corporations even after the rule of reason opinion in the Standard Oil case in 1911.

70 "The three major variants of corporate liberalism that emerged in American national politics during the Progressive Era and attained some degree of well-defined clarity by 1910-1912 were: (1) a statist-tending corporate 
the large corporation as inevitable and progressive. ${ }^{71}$ However, he also believed that government intervention was required "in the national interest to assure social welfare.,"72 In 1908, Wilson stated, "no one now advocates the old laissez-faire, no one questions the necessity of a firm and comprehensive regulation of business operations.",73 According to Wilson, "big business is no doubt to a large extent necessary and natural. The development of business upon a great scale, upon a great scale of cooperation, is inevitable, and, let me add, is probably desirable."74 Whatever Wilson meant by the "old" laissez-faire, his administration embraced a policy ideology of minimal business regulation, little economic management of the economy, and strong deference to the gold standard.

Louis Brandeis was the chief economic advisor to Woodrow Wilson from 1912 - 1916, before Wilson appointed Brandeis to the Supreme Court in 1916. Brandeis served on the Court until his retirement in $1939 .^{75}$ Brandeis was far more critical of big business then was Wilson. He argued that the big corporations could not be justified by scale economies. Brandeis believed smaller businesses were often more efficient then their larger competitors and concluded that firms of excessive size were typically the result of unfair practices and not natural growth. ${ }^{76} \mathrm{He}$

liberalism on the left associated with Theodore Roosevelt; (2) a regulatory corporate liberalism on the center left, associated with Woodrow Wilson; and (3) a minimalist-regulatory corporate liberalism on the center right, associated with William Howard Taft. Martin Sklar, The Corporate Reconstruction of American Capitalism 18901916, Cambridge (1988) at 35.

${ }^{71} I d$. at 393.

${ }^{72} I d$. at $404,415$.

${ }^{73}$ Quoted in $I d$. at 406.

${ }^{74}$ Quoted in Gabriel Kolko, The Triumph of Conservatism: A Reinterpretation of American History, 1900-1916. Free Press (1962) at 209.

${ }^{75}$ Thomas K McCraw, Prophets of Regulation, Harvard, (1984) at 82, 135.

${ }^{76} I d$. at 108,112 . 
opposed the influence of the financial sector, ${ }^{77}$ but supported fair trade laws that sanctioned resale price maintenance. ${ }^{78}$ Also, like Wilson, Brandeis did not support the interests of labor. ${ }^{79}$

In 1914, the Wilson administration passed the last two major pieces of antitrust legislation, the Clayton Act and the Federal Trade Commission (FTC) Act. The National Civic Federation legislative agenda and the failed Hepburn bill strongly informed both laws. As Weinstein related, "the principles underlying the FTC were enunciated by corporation leaders and their lawyers consistently throughout the Progressive Era in response to a series of legislative and judicial actions stretching over some seventeen years." 80 The Federal Trade Commission Act established a commission to carry out investigations, issue cease and desist orders, all subject to judicial review. Big business did not get the provision it sought, namely a commission that could immunize business strategies. ${ }^{81}$

In contrast to the FTC Act, the Clayton Act provided greater certainty by defining specific prohibited practices. The experience of the AFL whose support the National Civic Federation had garnered by promises of an antitrust exemption is instructive. Wilson, like Roosevelt, opposed a labor exemption. ${ }^{82}$ However, labor did have some congressional support and the AFL was able to obtain language in the Clayton Act stating that human labor is not a

\footnotetext{
${ }^{77}$ Louis Brandeis, "Other People's Money and How the Bankers Use it" quoted in Melvin Urofsky, Louis Brandeis: A Life, Schoken (2012) at 322.

${ }^{78}$ Jeffrey Rosen, Louis D. Brandeis: American Prophet, Yale (2016) at 79.

${ }^{79}$ Gabriel Kolko, The Triumph of Conservatism: A Reinterpretation of American History, 1900-1916, Free Press (1962) at 207-208.

${ }^{80}$ James Weinstein, The Decline of Socialism in America 1912-1925, Vintage (1969) at 62.

${ }^{81}$ Gabriel Kolko, The Triumph of Conservatism: A Reinterpretation of American History, 1900-1916. Free Press (1962) at 264. According to William Letwin, Wilson did not want to establish a powerful executive agency that could be viewed as putting government in charge of the trusts. This would have been tantamount to establishing the very system Wilson had accused Roosevelt of advocating. William Letwin, Law and Economic Policy in America: The Evolution of the Sherman Antitrust Act, Chicago (1965) at 273.

82 "The New York Times reported on February 2, 1914 that the president had let it be known that he would veto any anti-trust measured that exempted labor from its provisions." Philip Foner, History of the Labor Movement in the United States Vol 5, Int. (1980) at 131.
} 
commodity (Section 6), as well as a qualified limitation of the labor injunction (Section 20). ${ }^{83}$ Unfortunately, the Supreme Court interpreted the Clayton Act language narrowly against labor immunity. The Court held that the Clayton Act did not exempt secondary boycotts, ${ }^{84}$ picketing, ${ }^{85}$ primary boycotts,${ }^{86}$ and most strike activity. ${ }^{87}$ The Court's opinions dashed the hopes of the labor unions, and the injunctions continued. Federal judges issued roughly 2,100 antilabor Sherman Act injunctions in the decade of the 1920s. ${ }^{88}$

World War I interrupted the potential implementation of Wilson's antitrust legislation in April 1917. ${ }^{89}$ In short order, the United States mobilized for the war effort. Wilson established the War Industries Board of 1917-1918 as a liaison between the military and American industry. It formed industrial trade committees to gather information, coordinate supply and stabilize prices. ${ }^{90}$ The trade committee structure appeared to successfully meet the needs of the American war machine. ${ }^{91}$ The methods employed during the war then continued into the post war period. Even after the hostilities subsided, managers at big businesses embraced industry cooperation

\footnotetext{
${ }^{83}$ See Elinor Hoffman, "Labor and Antitrust Policy: Drawing a Line of Demarcation," 50 Brook. L. Rev. 1, 20-25 (1983). See also Robert Lande and Richard Zerbe, "Anticonsumer Effects of Union Mergers: An Antitrust Solution," 46 Duke L. J. 197, 205 (1996).

${ }^{84}$ Duplex Printing Press Co. v. Deering, 254 U.S. 443 (1921).

${ }^{85}$ American Foundries v. Tri-City Central Trades Council, 257 U.S. 184 (1921).

${ }^{86}$ Bedford Cut Stone Co. v. Journeymen Stone Cutters' Ass'n, 274 U.S. 37 (1927).

${ }^{87}$ Colorado Coal Co. v. United Mine Workers, 268 U.S. 295 (1925); Duplex Printing Press Co. v. Deering, 254 U.S. 443 (1921); United Mine Workers v. Coronado Coal Co., 259 U.S. 344 (1922).

${ }^{88}$ William Forbath, Law and the Shaping of the American Labor Movement, Harvard (1989) at 118 ("the 1920s not only witnessed the greatest number of anti-strike injunctions (roughly 2100)..."). In 1932 a labor exemption was obtained from the passage of the Norris-LaGuardia Act.

${ }^{89}$ The date of Wilson's Declaration of War.

90 Robert Cuff, The War Industries Board: Business-Government Relations During World War I, Johns Hopkins (1973) recounts the experience of the War Industries Board.

91 As Cuff described, "Individual success, however, could not remove the unstable, uncertain, and fractionalized nature of the early committee system, and it is this side of the experience which needs to be emphasized if we are to understand the evolving business drive for centralized control." Id. at 73.
} 
through the new trade association movement. ${ }^{92}$ Consulting firms such as Stevenson, Jordan \& Harrison emerged to facilitate the formation and management of private trade associations. As during the war, these private trade associations would gather, organize, and disseminate information about prices, costs and other market information, coming close to or actually implementing cartel formation in plain sight. ${ }^{93}$ In 1921, President Harding appointed Herbert Hoover as Secretary of Commerce. From his position as Secretary of Commerce, Hoover also encouraged the trade association movement. "He fully expected that a modern commitment to managerial science and industrial engineering would provide the rational ground for a new commercial ethic of cooperative competition." ${ }^{94}$ This approach would also obtain Franklin Roosevelt's blessing in the first New Deal, but then be abandoned.

\section{b. $\quad$ The Rise of Instability and the Great Depression}

There is no simple explanation for the great crash and the ensuring depression that occurred at the end of the 1920s. Any attempted explanation must distinguish between the initial downturn and the propagating mechanisms that exacerbated and prolonged the decline. This paper argues that the instability associated with the rise of big business and the dominance of finance in the Progressive Era was an impetus for the initial decline, and the laissez-faire policy regime of the era limited the possible policy responses that might have precipitated an earlier recovery. Under the laissez-faire policy regime, expansionary fiscal policy was deemed illegitimate, and monetary policy was limited by a religious adhesion to the gold standard.

\footnotetext{
${ }^{92}$ Big business claimed that it was addressing the "ruinous competition" problem from the Gilded Age.

${ }^{93}$ See American Column \& Lumber Co. v. United States, 257 U.S. 377 (1921); Maple Flooring Manufacturers' Association v. United States, 268 U.S. 563 (1925); Cement Manufacturers' Protective Association v. United States, 268 U.S. 588 (1925). It is noteworthy that Justice Brandeis in his dissent in American Column \& Lumber Co. supported the formation of trade associations as long as they were "voluntary." "The Sherman Law does not prohibit every lessening of competition; and it certainly does not command that competition shall be pursued blindly, that business rivals shall remain ignorant of trade facts or be denied aid in weighing their significance." 257 U.S. 415.

${ }^{94}$ Rudolph Peritz, Competition Policy in America 1888-1992: History, Rhetoric, Law, Oxford (1996) at 86.
} 


\section{Big Business, Finance and Instability}

The 1920s was a period of relatively high wages. Real wages had risen sharply during the deflation that occurred in 1921 and continued to rise throughout the decade. ${ }^{95}$ The real wage increased by $7 \%$ in $1921 .{ }^{96}$ It continued to increase by just short of $3 \%$ per year in the 1920 s. $^{97}$ Big business responded by intensifying the generalization of new management practices and the use of new technologies. ${ }^{98}$ Referring again to Figure 1, we see that the rate of profit in the 1920s was relatively low despite these induced technological changes. The technological advances of the 1920s demonstrate the progressive side of big business. In addition to advances in management, Alex Field describes how much of the progress in 1920s manufacturing involved the electrification of factories. Electrification allowed factories to be contained within one-story buildings, and electricity could efficiently power a moving assembly line. ${ }^{99}$ However, these benefits came with a cost. Large interconnected firms with strong management gave rise to macroeconomic instability, because the well managed firms reacted more strongly to economic shocks, and the reactions quickly permeated widely through an interconnected network of firms.

\footnotetext{
${ }^{95}$ Restrictive anti-immigration quotas passed in 1921 and 1924 contributed to rising wages. Robert Gordon, The Rise and Fall of American Growth, Princeton (2016) at 281. However, Thomas Ferguson and James Galbraith raise important doubts about whether nominal wages increased during the 1920s. See Thomas Ferguson and James Galbraith, "The American Wage Structure: 1920-1947," 19 Research in Econ. Hist. 205, 222 (1999) (Their Figure 7 presents wage data by sector that indicates wages in most sectors declined during the beginning of the 1920s, with the exception of the capital goods industry. Thereafter, wages in most sectors are approximately constant until 1932).

96 Appendix I. There is support the wage data for this period in Appendix I. F. Mills, "Economic Tendencies in the United States: Aspects of the Pre-War and Post-War Changes," NBER (1932) at 231 ("In 1921, these costs [labor costs] were $38 \%$ above the 1914 level. The reduction in labor costs that followed the business advance from 1921 to 1923 left these costs still high, more than 26\% above the 1914 standard"); H. Moulton, "Income and Economic Progress", Washington, Brookings (1935) (finding a similar wage increase in 1921).

${ }^{97}$ Appendix I.

${ }^{98}$ Gérard Duménil, Mark Glick and Jose Rangel, Theories of the Great Depression: Why Did Profitability Matter? 19 Rev. of Rad. Econ. 16, 29-32 (1987); Paul David and Gavin Wright, "Early Twentieth Century Productivity Growth Dynamics: An Inquiry into the Economic History of "Our Ignorance," Discussion Paper in Economic and Social History Number 33, Oxford, October, 1999 at 1 ("A marked acceleration of total factor productivity (TFP) growth in the US followed World War I...rising real wages provided strong impetus to changes in workforce recruitment and management practices that were underway in some branches of the economy before the war.").
}

${ }^{99}$ Alexander Field, A Great Leap Forward: 1930s Depression and U.S. Economic Growth, Yale (2011) at 47. 
Peter Temin has demonstrated that the initial downturn in 1929 was strongest in the industries dominated by the large efficient firms. ${ }^{100}$ When an economic shock affects a large well-managed firm, the firm reacts immediately to avoid a rise in costs. For example, to avoid an inventory buildup following a demand shock, managers may swiftly cut production and curtail purchases of inputs. These reactions then cascade through the interconnected structure of production and distribution causing a recession. ${ }^{101}$

The size and power of the financial sector also grew in the 1920 s. $^{102}$ Carmen Reinhart and Kenneth Rogoff demonstrated how the financial sector has an unbroken record of creating instability through financial and banking crises. ${ }^{103}$ As mentioned earlier, in the $1920 \mathrm{~s}$, the primary source of financing for big business derived from the issuance of stocks and bonds. Wholly owned affiliates of the big banks sold these securities to the public, who in turn, financed these investments by call loans through brokers. ${ }^{104}$ This structure required large firms to

\footnotetext{
100 Peter Temin, Lessons from the Great Depression, MIT (1991) at 163 ("More concentrated industries and industries where the largest 50 firms were important appear to have suffered the largest decline in production").

${ }^{101}$ There are also alternative explanations of the initial recession in 1929. John Kenneth Galbraith describes how the increase in interest rates by the Fed to stem the rise in the stock market. These rates caused a flow of capital into the United States, which caused increased rates by the Bank of England. See John Kenneth Gailbraith, The Great Crash of 1929, Mariner (1954) at 24-38.

${ }^{102}$ Financialization is associated with high income inequality, low investment and instability. Apostolos Fasianos, Diego Guevara and Chistos Pierros, "Have we Been Here Before? Phases of Financialization within the $20^{\text {th }}$ Century in the United States," Levy Economic Institute, Working Paper 869, June 2016 at 3.

${ }^{103}$ Carmen Reinhart and Kenneth Rogoff, This Time is Different Eight Centuries of Financial Folly, Princeton (2009) (documenting "the long history of financial crises in their many guises across many countries"); Robert Aliber and Charles Kindleberger, Manias, Panics Crashes: A History of Financial Crises, Palgrave (2005).

104 This structure is described in Eugene White, "The Stock Market Boom and Crash of 1929 Revisited," 4 J. of Econ Persp. 67, 69 (1990). My interpretation of the causes of the great depression comes from Gérard Duménil and Dominique Levy, "The Great Depression: A Paradoxical Event" CEPREMAP (1995) and Gérard Duménil, Mark Glick and Jose Rangel, Theories of the Great Depression: Why Did Profitability Matter? 19 Rev. of Rad. Econ. 16 (1987); Gérard Duménil and Dominique Levy, "The Great Depression: A Paradoxical Event" CEPREMAP (1995) at 11-13 (estimating the size of overall size of the heterogeneity of capital).
} 
dedicate a large portion of its profits to dividends, ${ }^{105}$ and by necessity, the fate of the stock market influenced investment decisions. ${ }^{106}$

\section{Propagation of the Crash and the Policy Failures}

In August 1929, the economy entered a recession. At the same time the stock market soared above the levels achieved in 1928 and the Q-ratio reached historic levels. ${ }^{107}$ The stock market then crashed in October 1929. ${ }^{108}$ As the economy entered the recession, a large sector of small less advanced traditional firms failed. ${ }^{109}$ Between 1929 and 1933, one third of all manufacturing establishments closed. ${ }^{110}$ This further deepened the depression.

Large firms stopped spending and began to hoard cash, while the surviving small firms unsuccessfully sought support from the credit system. ${ }^{111}$ Duménil and Levy attribute the

105 Apostolos Fasianos, Diego Guevara and Chistos Pierros, "Have We Been Here Before? Phases of Financialization within the $20^{\text {th }}$ Century in the United States," Levy Economic Institute, Working Paper 869, June 2016 at 14 (showing that on average retained earnings were negative in the progressive era); Gérard Duménil, Mark Glick and Jose Rangel, Theories of the Great Depression: Why Did Profitability Matter? 19 Rev. of Rad. Econ. 16, 34 (1987) ("The last few years, 1926-1929, produced exceptionally unsatisfactory internal returns [retained earnings] as a result of the low profitability combined with the high rate of payout of dividends." And presenting a graph of the profile of retained earnings in the 1920s).

${ }^{106}$ A third contributing factor to the weakness of the economy in the 1920s was the disruption of the international economic environment caused by World War I. The war disrupted the stability that had existed under the gold standard, and the subsequent misguided attempts at restoration were destabilizing. Peter Temin, Lessons from the Great Depression, MIT (1991) at 10

107 Eugene White, “The Stock Market Boom and Crash of 1929 Revisited,” 4 J. of Econ Persp. 67, 73 (1990);

${ }^{108}$ For a detailed description of the stock market crash see John Kenneth Galbraith, The Great Crash 1929, Mariner (1954). For a description of several theories of how the stock market crash influenced the real economy see Christine Romer, "The Great Crash and the Onset of the Great Depression,” 105 Q.J. of Econ 597 (1990).

109 Timothy Bresnahan and Daniel Raff, "Intra-Industry Heterogeneity and the Great Depression: The American Motor Vehicles Industry, 1929-1935," 51 J. of Econ. Hist. 317 (1991); Gérard Duménil and Dominique Levy, “The Great Depression: A Paradoxical Event" CEPREMAP (1995) at 20.

${ }^{110}$ Gérard Duménil and Dominique Levy, "The Great Depression: A Paradoxical Event” CEPREMAP (1995) at 5 ("the number of establishments within Manufacturing, culminated at 206,663 in 1929, and declined to 139325 in 1933”); Timothy Bresnahan and Daniel Raff, "Intra-Industry Heterogeneity and the Great Depression: The American Motor Vehicles Industry, 1929-1935," 51 J. of Econ. Hist. 317,317-318 (1991) (Between 1929 and 1933, one-third of U.S. manufacturing establishments closed").

111 Helen Hunter, "The Role of Business Liquidity During the Great Depression and afterwards: Differences between Large and Small Firms" 42 J. of Econ. Hist. 883 (1982) ("Cash managers of very large firms in the 1920s and 1930s responded to business downswings by substantially increasing their ratios of case balances to receipts. 
problem to the increased riskiness of lending to small firms. ${ }^{112}$ These practices resulted in further declines in output and prices, which increased the perceived risk of lending to the traditional firms even further. A vicious cycle ensued. Moreover, the deflation that accompanied the crash increased the real rate of interest on existing debt again worsening the insolvency of many firms. ${ }^{113}$

A banking crisis occurred in October 1930, followed by two further episodes of bank closures in 1931 and $1933 .{ }^{114}$ In the face of both a credit crisis and a series of banking crises, ${ }^{115}$ the federal government and the new Federal Reserve System seemed completely paralyzed. ${ }^{116}$ While there is no consensus on a complete explanation of the Great Depression, what remains undeniable is that the laissez-faire policy regime of the 1920s culminated in a stunning economic catastrophe. ${ }^{117}$ In response, the federal government during the New Deal era would experiment with new institutional arrangements involving changing class alliances, and new economic and

This withdrawal of funds from the spending stream was large enough to have contributed to the severity of the Great Depression.").

${ }^{112}$ Gérard Duménil and Dominique Levy, "The Great Depression: A Paradoxical Event" CEPREMAP (1995) at 27. See also Ben Bernanke, "Non-Monetary Effects of the Financial Crisis in the Propagation of the Great Depression," NBER (1983).

${ }^{113}$ Gérard Duménil and Dominique Levy, "The Great Depression: A Paradoxical Event" CEPREMAP (1995) at 2728. See also Ben Bernanke, "Non-Monetary Effects of the Financial Crisis in the Propagation of the Great Depression,” NBER Working Paper \#1054, January 1983.

${ }^{114}$ In Chapter 7 of Milton Friedman and Anna Schwartz's A Monetary History of the United States, 1867-1960 the authors argue that the banking crisis was the primary cause of the depression. For a criticism of this viewpoint see Peter Temin, Did Monetary Forces Cause the Great Depression?, Norton (1976). Temin finds no increase in the rate of interest in 1929-1930 indicating that "We conclude that the money hypothesis has failed its most important test. There is no reason to think that the monetary stringency in 1929-1930 was more severe than in other interwar depressions and no evidence that the bank failures in 1930 created such a stringency." Id. at 126.

${ }^{115}$ The banking crises are described in great detail in Jill Hendrickson, Regulation and Instability in US Commercial Banking: A History of Crises, Palgrave (2011) at 127-142.

${ }^{116}$ For an analysis of the various theories for the inept Federal Reserve response see Gerald Epstein and Thomas Ferguson, "Monetary Policy, Loan Liquidation, and Industrial Conflict: The Federal Reserve and the Open Market Operations of 1932," 44 J. of Econ. Hist. 957 (1984).

${ }^{117}$ Other factors included the decline in construction spending, international banking crises, Britain's return to the gold standard, the indebtedness of agriculture and other factors. Peter Temin addressed the many factors involved in the depression in Peter Temin, Did Monetary Forces Cause the Great Depression, Norton (1976). 
political policies, including antitrust policy. The New Deal would eventually resurrect the dismal U.S. economy and create one of the most profitable periods in U.S. history.

\section{The New Deal and the Great Leap Forward}

The New Deal initiated a new policy regime that would achieve stunning success, and propel the U.S. economy into the most prosperous period of its history. There is significant consensus among economic historians that "the years 1929-1941 were, in the aggregate, the most technologically progressive of any comparable period in the U.S. economic history." "118 The combination of regulated finance, recognition of unions, social support policies, and strong antitrust policy resulted in lower inequality, greater technological change, higher profits and higher productivity. Moreover, the New Deal put in place the apparatus for stronger countercyclical macroeconomic policy. This policy regime would survive until it was eclipsed by the regime of neoliberalism, including the Chicago School of antitrust during the crisis of the 1970s.

\section{a. $\quad$ The First Order of Business: Suppress the Influence of Finance}

On March 4, 1933, at the nadir of the depression, Franklin Roosevelt was inaugurated. As Thomas Ferguson aptly described, "taking office at the moment of the greatest financial collapse of the nation's history, President Franklin D. Roosevelt initiated a dazzling burst of government actions designed to square the circle that was baffling governments elsewhere: how to enact major social reforms while preserving both democracy and capitalism."119 In his

\footnotetext{
118 Alexander Field, "The Most Technologically Progressive Decade of the Century," 93 Amer. Econ Rev. 1399 (2003).

${ }^{119}$ Thomas Ferguson, "From Normalcy to New Deal: Industrial Structure, Party Competition, and American Public Policy in the Great Depression," 38 Int. Org. 41 (1984). Ferguson attributed the Roosevelt change in policy to a realignment of corporate interests in the face of a challenge from labor. The center of the coalition that created the New Deal policy measures was "a new power bloc of capital-intensive industries, investment banks, and internationally oriented commercial banks". "Their support permitted Roosevelt to emerge as the guardian of all the millions, and to initiate a set of policies that delivered unprecedented benefits to the general population while
} 
inaugural speech, Roosevelt stated what many thought at the time, that the economic crisis was the creation of "the unscrupulous money changers." 120 Two days later on March 6, Roosevelt declared a national bank holiday. ${ }^{121}$

Then in June 1933, Roosevelt signed into law the 1933 Banking Act, also known as the Glass Steagall Act. Its most important provisions were the separation of commercial and investment banking ${ }^{122}$ and the establishment of the Federal Deposit Insurance Corporation (FDIC). ${ }^{123}$ The Act addressed the swelling public concern that financial interests had diverted bank credit into speculation rather than productive uses. The 1933 Act also preserved the prohibition on interstate branch banking, and prohibited interest on demand deposits. ${ }^{124}$ Regulation Q allowed the Fed to set rates on time deposits. Collectively, the 1933 and 1935 Banking Acts created a banking system that limited competition between banks, and severed bank interconnections, to preserve stability and prevent contagion. The approach was successful. Only two banks failed in the first two terms of the Roosevelt presidency, and there were few large bank failures until bank deregulation began under neoliberalism. ${ }^{125}$

In addition, the Banking Act of 1935 considerably strengthened the Federal Reserve System by wresting control of the Open Market Committee from the regional banks and placing

satisfying a leading segment of American business." Thomas Ferguson and Joel Rogers, Right Turn: The Decline of the Democrats and the Future of American Politics, Hill and Wang (1986) at 46, 48.

${ }^{120}$ Quoted in Michael Hiltzik, The New Deal: A Modern History, Free Press (2011) at 26.

${ }^{121}$ Roosevelt also imposed controls on foreign exchange trading and gold exports. This allowed Roosevelt to devalue the dollar on April 18. Peter Temin, Lessons from the Great Depression, MIT (1991) at 96-97.

122 Jill Hendrickson, Regulation and Instability in US Commercial Banking: A History of Crises, Palgrave (2011) at 147.

${ }^{123}$ Jill Hendrickson, Regulation and Instability in US Commercial Banking: A History of Crises, Palgrave (2011) at 144 ("according to the Banking Act of 1933, to be eligible for deposit insurance, membership into the Federal Reserve system was required" the 1935 Act extended the time period to join the FED to 1942).

${ }^{124}$ The 1933 Act retained the prohibition on interstate branch banking established by the 1927 McFadden Act.

${ }^{125}$ Anthony J. Badger, the New Deal: The Depression Years, 1933-1940, Ivan R. Dee (1989) at 73. 
it under the Federal Reserve Board, thereby increasing its effectiveness. ${ }^{126}$ The Securities Act of 1933 required disclosure of accurate information about securities, and outlawed false statements. The Securities and Exchange Act of 1934 created the Securities and Exchange Commission to regulate securities markets. Critically, these measures combined to curtail the negative influence that finance had exercised over the economy.

\section{b. The Early New Deal}

New Deal policy was never entirely consistent. Roosevelt's early actions succeeded in limiting the power of finance, but in 1933, he did not have wide-ranging plans for industrial restructuring. In June 1933, Congress passed the National Industrial Recovery Act (NIRA). The logic of NIRA harkened back to the success of the War Industries Board and was based on the Gilded Age theory that ruinous competition was inimical to capitalist stability. Hugh Johnson, one of the leaders of the War Industries Board headed the NRA, the agency created by the NIRA. Title I of NIRA created the industry codes that established prices and policy for industry participants. The opaque Section 7(a) guaranteed the right of labor to organize and collectively bargain. Section 5 exempted the codes from the Sherman Act. ${ }^{127}$ The NRA enacted 546 industrial codes covering 550 industries and it issued 11,000 orders interpreting various code sections.

Roosevelt asked Clarence Darrow to head an NRA review board in 1934. The Darrow Report concluded that NRA was essentially creating small monopolies and labor rights were not improving. ${ }^{128}$ Before Congress, Darrow testified, "the whole thing was obviously made for the

\footnotetext{
${ }^{126} I d$. at 72-73. On April 20, 1933 Roosevelt left the gold standard that arguably also provided more leeway for FED monetary policy.

${ }^{127}$ The Blue Eagle Emblem, the trademark of the NRA, was the origin of the Philadelphia Eagles.

${ }^{128}$ National Recovery Review Board: First Report to the President of the United States (1934).
} 
rich man-for big business." ${ }^{129}$ Moreover, Johnson's interpretation of the collective bargaining was largely limited to company unions and NRA did not effectively contribute to union strength. ${ }^{130}$ The Supreme Court ultimately declared NIRA unconstitutional in A.L.A. Schechter Poultry Corp. v. United States, 295 U.S. 495 (1935).

\section{c. $\quad$ The Later New Deal}

While the early New Deal took many twists and turns, a consistent theme emerged following the demise of NRA. The policy convergence centered on efforts to reduce the power and income of big business, and increase the income and power of the other classes. Ellis Hawley refers to this policy aim as "counterorganization":

But if one insisted on a dominant theme, he could probably find it in the concept of counterorganization, in the idea of using the government to promote the organization of economically weak groups, thus restoring economic balance... The advantages of stronger economic organization had long been stressed by labor, farm, and small business groups. The relatively new element was the attempt of these groups to enlist governmental aid in developing market power. Labor leaders had now abandoned their former devotion to 'voluntarism' and were urging that the government foster unionization, absorb the unemployed, and regulate wages and hours. ${ }^{131}$

A cornerstone of the new approach was a change in the relationship between the state and

labor. Before the New Deal, state policy, and in particular antitrust policy, was largely antilabor. ${ }^{132}$ When NIRA was held unconstitutional in 1935, Congress reacted by passing the more

\footnotetext{
${ }^{129}$ Quoted in Ellis Hawley, The New Deal and the Problem of Monopoly: A Study in Economic Ambivalence, Fordham (1995) at 124.

${ }^{130}$ Michael Hiltzik, The New Deal: A Modern History, Free Press (2011) at 130 ("Johnson cavalierly held that Section 7(a) could be served by the establishment of a 'company union"').

${ }^{131}$ Ellis Hawley, The New Deal and the Problem of Monopoly: A Study in Economic Ambivalence, Fordham (1995) at 187. An economic justification for this approach came from Harold Moulton and others at the Brookings institution that stressed the unequal distribution of income as leading to a demand problem that impeded economic recovery. See Harold Mouton, Income and Economic Progress, Brookings (1934).

${ }^{132}$ As described by William Forbath, until the Norris-LaGuardia Act the antitrust laws were primarily used against labor. Even in the 1920s, "courts issued more than 2,100 anti-strike decrees." Approximately 25\% of all strikes
} 
effective National Labor Relations Act (the "Wagner Act"), curbing the ability of employers to combat unions. $^{133}$ As a result, union membership tripled in the 1930s. By 1945, 25\% of the American work force had unionized. ${ }^{134}$ Roosevelt also passed the nation's first minimum wage law of $\$ .25$ per hour and limited the working day to 40 hours. ${ }^{135}$ Other measures included the Social Security Act, which increased the income of the elderly, and established a system of unemployment insurance, the Railroad Retirement Board, the Works Progress Administration, Civilian Conservation Corps, and the National Youth Administration, which provided income for the unemployed. The Agricultural Adjustment Act issued support to the $30 \%$ of the population that were still farmers in 1935. Critically, progressive taxation and a new, revitalized commitment to antitrust enforcement served as a check on the income of big business. ${ }^{136}$ Following the recession in 1937, Roosevelt began to embrace Keynesian fiscal policy.

The Neo-Brandeisians had been lobbying Roosevelt throughout the NRA period to revitalize United States antitrust policy. ${ }^{137}$ After NRA was declared unconstitutional they got their chance. In 1937, Robert Jackson (a Neo-Brandeisian and admirer of Woodrow Wilson) was appointed head of the Department of Justice's Antitrust Division, a position he held until March 1938. During his short tenure, he brought two landmark cases that would guide antitrust law in the post-World War II period: United States v. Socony-Vacuum Oil Company and United

were met by injunctions. In addition, the rise of the doctrine of substantive due process and "freedom of contract" undermined labor's efforts to pass prolabor legislation. See William E. Forbath, Law and the Shaping of the American Labor Movement, Harvard U.P. (1989).

${ }^{133}$ Frank Levy and Peter Temin, "Inequality and Institutions in $20^{\text {th }}$ Century America", NBER Working Paper 13106, May 2007, at 16.

${ }^{134}$ Anthony Badger, The New Deal: The Depression Years, 1933-1940, Ivan Dee (1989) at 118.

135 The 1938 Fair Labor Standards Act.

136 Anthony J. Badger, the New Deal: The Depression Years, 1933-1940, Ivan R. Dee (1989) at 103 ("the 1935 Revenue Act eventually hoisted top personal income tax rates from 63 percent to 79 percent, sharply graduated the income tax to penalize big corporations, and boosted estate taxes.").

137 The Neo-Brandeisions were the New Deal lawyers influenced by Louis Brandeis. They included, among others, Felix Frankfurter, Ben Cohen, James Landis and Tommy Corcoran. 
States v. Aluminum Company of America. ${ }^{138}$ In March 1938, Thurman Arnold replaced Robert Jackson at the Antitrust Division and served until 1943. Arnold rebuilt the Antitrust Division by significantly increasing its size and budget. ${ }^{139}$ From 1939 to 1941, the Antitrust Division filed more than 180 cases. ${ }^{140}$ By the time Arnold left the Antitrust Division in 1943, he participated in almost half of all Sherman Act cases ever brought up to that time. ${ }^{141}$ This new potent antitrust policy continued to expand during the golden age of capitalism that followed.

\section{d. $\quad$ The Later New Deal and the Remarkable U.S. Economic Performance}

The New Deal policy was remarkably effective. At the end of the 1920s, the top $1 \%$ of the population garnered approximately $24 \%$ of total income. ${ }^{142}$ During the 1930 s, this number dropped to $16.6 \%$ before continuing to drop into the post-World War II period. ${ }^{143}$ The New Deal policies of encouraging strong labor unions, more equitable income distribution, high wages, and vigorous antitrust policy resulted in the most spectacular increase in productivity and GDP growth in the history of the United States. The average rate of return on capital in the 1920s was nearly $14 \% .{ }^{144}$ The economy recovered to this level of profits by 1937 . From 1940-1949 the

\footnotetext{
${ }^{138}$ R. Hewitt Pate, "Robert H. Jackson at the Antitrust Division," 68 Alb. L. Rev. 787 (2005).

${ }^{139}$ Spencer Waller, "The Antitrust Legacy of Thurman Arnold," 78 St. John's L. Rev 569, 582 (2004) ("the number of Antitrust Division employees grew from eighteen to nearly five hundred, and the budget more than quadrupled."). In addition, Arnold, Jackson and others convinced Roosevelt to ask for a study of the monopoly problem in the United States. In June 1938 Congress approved the Temporary National Economic Committee (TNEC). The TNEC report in March 1941 recommended, among other things, prohibiting horizontal mergers above $\$ 5$ million, federal regulation of trade associations, mandatory patent licensing, and national chartering of corporations. During his tenure, Congress also commissioned a study of concentration in the United States. Between 1938 and 1941, the Temporary National Economic Committee studied concentration and the economic structure of the economy. However, it had little influence on Arnold's antitrust policy.

${ }^{140}$ Ellis Hawley, The New Deal and the Problem of Monopoly: A Study in Economic Ambivalence, Fordham (1995) at 460-466.

${ }^{141}$ Ellis Hawley, The New Deal and the Problem of Monopoly: A Study in Economic Ambivalence, Fordham (1995) at 441.

${ }^{142}$ Appendix I

${ }^{143} I d$.

${ }^{144}$ Id.
} 
rate of profit increased to $23 \% .^{145}$ It never again declined to the level of the 1920 s until the 1980s. ${ }^{146}$

Figure 1 depicts the striking growth in profits from the 1930s through World War II. These remarkable achievements occurred in an environment of diminished international trade, as global trade had collapsed during World War I and did not revive until 1945. There can be no doubt that between the 1920s and the end of World War II the American economy experienced a major economic advance. ${ }^{147}$ The average total factor productivity ${ }^{148}$ for the years 1900 to 1920 was about $1 \%$. The average for the decade of the 1920 s was $2 \%$. It grew to $3 \%$ in the 1930 s, and $2.5 \%$ for the $1940 \mathrm{~s}$. It remained high at $2 \%$ for the years 1950 to 1973 , but then dropped to below $1 \%$ for the period 1973 to 1990 . The reasons for this huge advance in productivity include, among other factors, the exploitation of the late nineteenth century inventions of electric power and the internal combustion engine, ${ }^{149}$ high wages, (a result of strong unions and New Deal legislation, particularly the National Labor Relations Act of 1935), ${ }^{150}$ and significant government intervention in the economy. High wages led to the substitution of capital for

\footnotetext{
145 Id.

${ }^{146}$ Id.

${ }^{147}$ Robert J. Gordon, "The Rise and Fall of American Growth: The U.S. Standard of Living Since the Civil War", Princeton U.P. (2016) at 535 ("The Great Leap Forward of the American level of labor productivity that occurred in the middle decades of the twentieth century is one of the greatest achievements of all of economic history.").

148 Total factor productivity is a measure of the advances in production technology and processes that are the primary drivers of economic growth. Robert Shackleton, "Total Factor Productivity Growth in Historical Perspective", Working Paper 2013-01, Congressional Budget Office, March 2013 at 1 ("Economists have long found that they can explain only a portion of economic growth by the growth of inputs to production, such as the number of hours worked or the amount of capital used. The unexplained (or residual) portion, which presumably reflects advances in production technologies and processes, is conventionally attributed to all of the production factors together and is referred to as total factor productivity (TFP) growth").

${ }^{149}$ Robert J. Gordon, "The Rise and Fall of American Growth: The U.S. Standard of Living Since the Civil War," Princeton U.P. (2016) at 555.

150 Another reason real wages were high during the early part of the Great Depression was the severe deflation. Even during a depression, lowering the money wage will face severe resistance from employees.
} 
labor. ${ }^{151}$ Alfred Keinknecht, for example, studied the timing of the implementation of major basic innovations. He found that the period from the 1930s to approximately the late 1940s produced more basic innovations and greater "product-related breakthrough patents" in the 1930s and 1940s than any other period. According to Alexander Field, "employment of research scientists and engineers grew 72.9 percent between 1929-1933 while employment totals in other occupational categories collapsed. Between 1933 and 1940, R\&D employment in U.S. manufacturing almost tripled, from 10,918 to $27,777 .{ }^{152}$ There is evidence of technical advances in the 1930s in a wide variety of industries including chemicals, automobiles, communications, electronics, transportation, construction, retail and wholesale trade, and other industries. ${ }^{153}$

\section{e. $\quad$ World War II and Continued Success of the New Deal Policies}

As early as 1939 the American economy began to respond to the Allies' increased demand for armaments. ${ }^{154}$ Then an explosion of defense spending began in 1940 when the Selective Service Act instituted the military draft. ${ }^{155}$ Federal expenditures escalated, and wartime production transformed the economy to meet the military need. ${ }^{156}$ In the 1920 s, the

\footnotetext{
151 See note 4, supra. Peter Temin also comes to this conclusion by comparing the Nazi low wage regime with the New Deal high wage regime. Peter Temin, Lessons from the Great Depression, MIT (1991) at 123.

152 Alexander Field, "The Most Technologically Progressive Decade of the Century," 93 Amer. Econ. Rev. 1399, 1406 (2003). Alexander Field, A Great Leap Forward: 1930s Depression and U.S. Economic Growth, Yale (2011) at $65-66$.

${ }^{153} I d$. at $1406-1409$.

${ }^{154}$ Robert Gordon and Robert Krenn, "The End of the Great Depression 1939-41: Policy Contributions and Fiscal Multipliers," NBER Working Paper (September 2010) at 12.

${ }^{155}$ Robert Gordon and Robert Krenn, "The End of the Great Depression 1939-41: Policy Contributions and Fiscal Multipliers," NBER Working Paper (September 2010) at 13. Harold Vatter, The U.S. Economy in World War II, Columbia (1985) at 11.

${ }^{156}$ Military production also drained resources from other parts of the economy. Alex Field, A Great Leap Forward: 1930s Depression and U.S. Economic Growth, Yale (2011) at 24 ("With respect to spillovers, there is at least as much evidence of transfer from civilian experience to military production during the war as there is for feedback in the other direction").
} 
ratio of federal spending to GDP was about $12 \%$, it rose to $20 \%$ during the New Deal, but at the peak of the war effort the size of federal spending was $45 \%$. During World War II the federal debt also grew even though government had increased the tax base to include virtually all Americans and top rates reached $94 \%$. The ratio of debt to GDP in 1938 was $43 \%$. It ballooned to $114 \%$ at the height of the military spending in 1945 . Most economists acknowledge that this expansionary fiscal policy contributed to the recovery from the depression. ${ }^{157}$

The government also contributed to the productive capacity of the economy by directly building production facilities for the war effort. These plants were government owned but operated by private businesses (GOPO). The government constructed aluminum plants, steel plants, machine tool facilities, plants to produce machine tools and dies, the massive Willow Run facility near Detroit, and numerous forts and bases. Most of these facilities were large-scale projects. ${ }^{158}$ In all, the government may have invested as much as $\$ 45$ billion in private industrial plants and equipment. ${ }^{159}$ After the war, private business purchased these assets under the Surplus Property Act of 1944, often at bargain prices. ${ }^{160}$

\footnotetext{
${ }^{157}$ For a contrary view see Christina Romer, "What Ended the Great Depression," 52 J. of Econ. Hist. 757 (1992).

${ }^{158}$ Louis Cain and George Neumann, "Planning for Peace: The Surplus Property Act of 1944," 41 J of Econ. Hist.129, 131 (1981).

${ }^{159}$ Robert Gordon, “\$45 Billion of U.S. Private Investment Has been Mislaid: Reply,” 60 Amer. Econ. Rev. 940 (1970); Robert Gordon, The Rise and Fall of American Growth, Princeton (2016) at 552. In particular, Gordon noted that "the number of machine tools in the U.S. doubled from 1940 to 1945, and almost all of these new machine tools were paid for by the government rather than private firms". Id. at 553. Many of the factories built by the government were of a massive scale including Keiser aluminum, the Ford Willow Run plant, Geneva Steel, and many others. See also, Louis Cain and George Neumann, "Planning for Peace: The Surplus Property Act of 1944," $41 \mathrm{~J}$ of Econ. Hist. 129 (1981) (estimating that \$18 billion in GOPO assets). Id. at 552.

${ }^{160}$ Alexander Field, "The Impact of World War II on the Growth of U.S. Potential Output," Univ. of Santa Clara, November 2017 at 30.
} 
The War Production Board also facilitated the expansion of existing capacity. ${ }^{161}$ Robert Gordon conveyed how, "the entire economy converted to a maximum production regime in which every machine and structure was used twenty-four hours per day if enough workers could be found to staff three shifts." ${ }^{162}$ Duménil, Glick and Levy showed that the maximum production regime resulted in the gigantic increase in the rate of profit by economizing on use of existing structures. ${ }^{163}$

The government also sponsored research that would become important after the war. The War effort resulted in advances in radar, materials science, microwave technology, and products such as the jet engine, heavy water, continuous catalytic cracking, silicone, teflon, nylon, the aerosol spray, accelerators, and streptomycin. Vernon Ruttan contended that the government's research efforts during the war also created radical "general purpose technologies" that would form the foundation of further post-World War II innovations. ${ }^{164}$ Ruttan included aircraft design, nuclear power, and computer technology as key general-purpose technologies that emerged from the war effort. ${ }^{165}$

The War Production Board received the power to grant immunity from antitrust scrutiny. ${ }^{166}$ Thurman Arnold had initiated investigations in steel, shipbuilding, aircraft,

${ }^{161}$ Id. at 74-76. Alan Milward, War, Economy and Society: 1939-1945, Univ. of Cal. (1979) at 64 (presenting production data and concluding that "The period 1940 to 1944 saw a greater expansion of industrial production in the United States than any previous period.").

${ }^{162}$ Robert Gordon, The Rise and Fall of American Growth, Princeton (2016) at 548-549.

${ }^{163}$ Gérard Duménil, Mark Glick, and Dominique Levy, "The Rise of the Rate of Profit during World War II," 75 Rev. of Econ. and Stat. 315 (1993).

${ }^{164}$ General Purpose Technologies are "revolutionary departures from existing technologies" and makes "possible new functions that the technology that it replaces could not perform." Vernon Ruttan, "Is War Necessary for Economic Growth, Oxford (2006) at 13-14.

${ }^{165} I d$. at $56,72,92$.

166 The National War Labor Board (NWLB) also extracted no strike pledges for the duration of the war. But the government also left worker pensions and health insurance exempt from profit taxes, which encouraged firms to expand worker benefits. 
petroleum, electric equipment, chemicals and other industries. ${ }^{167}$ All of these investigations were suspended during the war. ${ }^{168}$ However, the government did attempt to use the sale of the government facilities to increase competition. For instance, it helped sponsor the entry of Reynolds Aluminum by selling it the government constructed aluminum facilities. This undermined the Alcoa monopoly. Antitrust enforcement would revive and expand after the war during the golden age of capitalism.

\section{The Golden Age of Capitalism}

The policy regime change initiated during the later New Deal continued after World War II for almost three more decades. ${ }^{169}$ Finance remained highly regulated. Antitrust, regulation, labor and corporate law checked the power of big business. The government embraced expansionary fiscal and monetary policy. The Bretton Woods agreement regulated international trade, and the volume of world trade grew at an annual rate of almost 7 percent between 1948 and $1990 .^{170}$

The U.S. economy emerged from World War II with modern technology, high wages, strong unions, low and declining inequality, and a political consensus favoring government management of the macro economy. ${ }^{171}$ The economy quickly advanced as patterns of R\&D and

\footnotetext{
${ }^{167}$ Ellis Hawley, The New Deal and the Problem of Monopoly: A Study in Economic Ambivalence, Fordham (1995) at 442.

${ }^{168} I d$.

${ }^{169}$ Thomas Ferguson dated the beginning of the disintegration of the New Deal coalition as 1966, the year the rate of profit began to rapidly decline. Thomas Ferguson and Jie Chen, "Investor Blocs and Party Realignments in American History," Journal of the Historical Society V, No. 4, at 536, 539; and discussion with Professor Ferguson.

${ }^{170}$ Dani Rodrik at 70-71.

${ }^{171}$ Alexander Field, A Great Leap Forward: 1930s Depression and U.S. Economic Growth, Yale (2011) at 107 (The "technological frontiers had been expanded by a host of new product and process innovations during the 1930s, and some of this potential had begun to be realized prior to the war. In other cases, such as television, all of the development work had been done before the war, and the new products were poised for rapid exploitation with the ending of controls after V-J Day").
} 
physical capital accumulation adjusted away from the contingencies of war production. ${ }^{172}$ During the 1950s and 1960s, the U.S. economy grew at an average rate of $4.4 \%$ per year. Unemployment averaged $4.6 \%$ per year. Inflation was low at an average of $2 \%$ and productivity was growing. ${ }^{173}$ At the same time, the United States was building the Great Society programs, constructing infrastructure, and the private sector was leading the world in industries such as consumer electronics, computers, as well as traditional industries such as automobiles and steel. ${ }^{174}$ In these decades, corporate profits were high and inequality was low. The average rate of profit for the period 1950-1969 was 11.7 percent, and the share of the top $1 \%$ of income earners was about $10.1 \%$ compared to approximately $18.8 \%$ in the $1920 \mathrm{~s} .{ }^{175}$

After World War II there was a brief period of strike activity and an effort to role back the power of unions, which included the passage of the Taft-Hartley Act of 1947. But the effort to destroy the power of labor failed. Instead, an implicit arrangement between labor and capital emerged. ${ }^{176}$ Unions agreed to give corporations autonomy in technological change and control over production and investment. In exchange, unions obtained expanded benefits and an expectation of wage increases tied to productivity increases. ${ }^{177}$ Emblematic of the implicit arrangement was the "Treaty of Detroit" which was the five-year UAW-GM labor contract

\footnotetext{
${ }^{172} I d$. at 3 (arguing that the focus of progress switched from manufacturing to transportation and distribution after the war).

${ }^{173}$ Appendix I.

${ }^{174}$ See Alfred D. Chandler, Inventing the Electronic Century: The Epic Story of the Consumer Electronics and Computer Industries, Harvard U.P. (2005), chapters 2, 4.

${ }^{175}$ Appendix I.

${ }^{176}$ However, labor faced several major failures in organizing the southern United States. Thomas Ferguson and Joel Rogers, Right Turn: The Decline of the Democrats and the Future of American Politics, Hill and Wang (1986) at 50-51 ("As early as the mid-1940s, for example, sharp internal conflicts were sapping the labor movement's organizational strength and momentum. Within a few years, 'Operation Dixie' - the much-vaunted union effort to organize the South - failed disastrously...").

${ }^{177}$ Orsola Costantini, "Invented in America: Birth and Evolution of the Cyclically Adjusted Budget Rule, 1933-61," 50 Hist. of Pol. Econ. 83, 106 (2018).
} 
negotiated in 1950 and emulated in other industries. This contract linked wage increases to inflation and productivity increases and provided workers with a pension plan and health insurance.

\section{a. Antitrust in the Golden Age of Capitalism}

The Golden Age of Capitalism was a period of activist antitrust enforcement. A broad per se rule for horizontal conspiracies prevailed based on the holding in United States v. SoconyVacuum Oil Co., 310 U.S. 150 (1940). One of the leading merger cases, Brown Shoe Co. v. United States, 370 U.S. 294 (1962), articulated the Congressional goals of merger policy to include ${ }^{178}$ preventing the "rising tide of concentration," control of vertical and conglomerate mergers, and recognition of non-economic concerns such as protecting political democracy. ${ }^{179}$ In Brown Shoe the Court found that an historical trend toward vertical integration along with a small foreclosure of less than $1 \%$ was sufficient to condemn the vertical merger, and post-merger market shares ranging from $5 \%$ to $57 \%$ in the various geographic markets were enough to render a horizontal merger illegal. Significantly, the Supreme Court stated that a merger that increases concentration cannot be "saved, because, on some ultimate reckoning of social or economic debits and credits, it may be deemed beneficial." In other words, efficiencies were not part of the Court's merger analysis. The Supreme Court also reaffirmed that small levels of foreclosure can condemn vertical mergers where the target is also a potential entrant, as in Ford Motor Co., v. United States, 405 U.S. 562 (1972).

The 1968 Merger Guidelines promulgated by the Department of Justice (DOJ) Antitrust Division embodied these principles. The guidelines stated that the DOJ would challenge mergers

\footnotetext{
${ }^{178}$ Brown Shoe was the first merger case following Congressional Amendments to Section 7 of the Clayton Act in 1950. See also N. Pac. R.R. v. United States,356 U.S. 1, 4 (1958) (Sherman Act goal included "preservation of our democratic and social institutions"); William Curran, "Democracy or Dagher? What Liberals Should Want," 56 Antitrust Bull. 883 (2011).

179370 U.S. at $312-315$.
} 
in markets where the four-firm concentration ratio is above $75 \%$ even when the acquiring and acquired firms have market shares smaller than $5 \%$. The criteria became more stringent when there was a trend toward concentration. The Guidelines prohibited vertical mergers involving supplying firms with $10 \%$ or more of sales in the market or purchasing firms with more than $6 \%$ of total purchases in the market, unless barriers to entry were low. The 1968 Merger Guidelines also challenged conglomerate mergers involving a potential competitor when the merging firms had significant market shares. ${ }^{180}$

\section{b. $\quad$ The Origins of the Chicago School}

The Chicago School of economics emerged from the crucible of a broader intellectual movement called neoliberalism. ${ }^{181}$ Allegedly, the term neoliberalism originated at the Walter Lippmann Colloquium in Paris in 1938. ${ }^{182}$ The Mont Pelerin Society, which held is first meeting in 1947, became the organizing hub of the neoliberal movement. Its leaders included Austrian economists Friedrich Hayek, Ludwig von Mises, Wilhelm Ropke, and Milton Friedman. George Stigler, Gary Becker and James Buchanan were frequent participants. ${ }^{183}$ The participants in the

\footnotetext{
${ }^{180}$ These Guidelines coincided with the period of FTC enforcement of the Robinson Patman Act ("RPT"). The FTC enforced the RPT act until the late 1960s and 1970s. It virtually abandoned all enforcement beginning in the 1980s when neoliberalism rose to prominence. See Mark Glick, David Mangum, and Lara Swensen, "Towards a More Reasoned Application of the Robinson-Patman Act: A Holistic View Incorporating Principles of Law and Economics in Light of Congressional Intent," 60 Antitrust Bull. 279 (2015). Hugh C. Hansen, "Robinson-Patman Law: A Review and Analysis," 51 Fordham L. Rev. 1114, 1174-1177 (1983).

181 Neoliberalism, generally refers to the ideological commitment to the extension of free markets and the minimization of government activity, except such activity which is aimed at the creation of markets (e.g., markets for corporate control, or the market for environmental permits). Neoliberalism advocates for financialization, globalization, corporate governance aimed exclusively at advancing shareholder interests, and acceptance of the attendant inequalities that result from these policies.

${ }^{182}$ Quinn Slobodian, Globalists: The End of Empire and the Birth of Neoliberalism, Harvard (2018) at 3-4; Philip Mirowski and Dieter Plehwe, The Road From Mont Pelerin, Harvard (2009) at 140 ("the rise of the Chicago School must be understood as one component of a specific larger transnational project of innovating doctrines of neoliberalism for the postwar world."). The title was in use by 1951, because in 1951 Milton Friedman wrote an essay titled "Neoliberalism and Its Prospects." Angus Burgin, The Great Persuasion: Reinvesting Free Markets Since the Depression, Harvard (2012) at 170.

${ }^{183}$ Philip Mirowski and Dieter Plehwe, The Road From Mont Pelerin, Harvard (2009) at 18.
} 
neoliberal movement did not have a unified theory in all respects. ${ }^{184}$ As the historian Ben Jackson describes, "Among the authors conventionally bracketed together as the founders of neoliberalism, there was, as might be expected, a spectrum of positions on these [economic] issues, rather than a uniform line." 185 What united these men was their opposition to expanding the role of the state, including opposition to regulation that protected unions and employees, government social programs, public or regulated enterprises and any obstacles to free trade. ${ }^{186}$

The two central figures in the neoliberal movement were Frederick Hayek and Milton Friedman. ${ }^{187}$ A key feature of both thinkers was the tendency to assume away the power and impact of big business. In The Road to Serfdom, published in 1944 Hayek argued that all types of state action, whether central planning or New Deal regulation, illegitimately infringed on human freedom of action. However, nowhere did he express any concern for the enormous growth in firm size, which places employees under the strict command and control of

\footnotetext{
${ }^{184}$ The various schools of neoliberal thought include the Chicago School, the Virginia Public Choice School, and the Washington consensus. In this paper we consider the Chicago School because of its focus on antitrust policy. However, the best introduction to the Public Choice literature is James Buchanan and Gordon Tullock, The Calculus of Consent: Logical Foundations of Constitutional Democracy, Univ. of Mich. (1962). See also, S. M. Amadae, Rationalizing Capitalist Democracy: The Cold War Origins of Rational Choice Liberalism, U. of Chicago (2003) at Ch. 3. There is also a large literature critical of Public Choice theory. See, e.g., Walter Block and Thomas DiLorenzo, "The Calculus of Consent Revisited", 3 Public Fin. \& Man. 305 (2001). Because of the extreme assumptions concerning rational utility maximizing behavior this literature is vulnerable to the advances in behavioral and experimental economics.

${ }^{185}$ Ben Jackson, “At the Origins of Neo-Liberalism: The Free Economy and the Strong State, 1930-1947," 53 The Historical J. 129, 140 (2010).

${ }^{186}$ In this section we recount the origins of neoliberal economic theory. For a more general history of neoliberal theory see Rachel S. Turner, Neo-liberal Ideology: History, Concepts and Policies, Edinburgh University Press (2008).

${ }^{187}$ While Hayek was a major figure there were other Austrian School critics of government intervention in the economy. One famous debate involved L. von Mises and Oscar Lange. Mises argued that rational economic calculations are impossible when there is public ownership. Lange developed a decentralized model of socialist planning that refuted Mises claim. Joseph Schumpeter presents a detailed economic analysis of the logic and viability of socialism. In his evaluation of the von Mises debate Schumpeter concluded that "There is nothing wrong with the pure logic of socialism" Joseph Schumpeter, Capitalism, Socialism and Democracy, Harper and Row (1942) at Chapter 16. For an interesting examination of the issues in light of modern economic developments see Fikret Adaman and Pat Devine, "The economic calculation debate: lessons for socialists," 20 Camb. J. of Econ 523 (1996).
} 
managers. ${ }^{188}$ Hayek posited that freedom is advanced only by the market, yet these big businesses are the result of market forces, not government action. Hayek further argued that any command and control regime would result in a failure of economic coordination. He argued that collective action distorts the price information necessary to achieving a position of economic equilibrium, a prerequisite for economic welfare. ${ }^{189}$ Since the publication of Hayek's work, economists have shown that, contrary to his assertions, market signals and information extracted from prices can yield destabilizing results. ${ }^{190}$ Hayek only assumed that information carried by market prices could achieve equilibrium and create favorable welfare outcomes. He never modeled the process nor did he marshal empirical evidence to support his supposition. Thus, there is little reason today to credit the policy prescriptions that he derived from this theory.

Milton Friedman, in his book, Capitalism and Freedom, also assumed large firms out of existence. Friedman recognized only two ways to organize society: "One is the central direction involving the use of coercion - the technique of the army and of the modern totalitarian state. The other is voluntary co-operation of individuals - the technique of the market place."191 $\mathrm{He}$ argued that the advantage of the market place is that it involves voluntary transactions in which both parties gain. He asserted that a society of individuals that contract voluntarily will result in

\footnotetext{
${ }^{188}$ Hayek does support a regime of competition but never explains in much detail what he meant. F.A. Hayek, The Road to Serfdom, U of Chi. (1944) at 85-86. But the point I am making is that while G.M. and Ford compete, workers in those plants are not making the kinds of free choices that Hayek is assuming.

${ }^{189}$ He did not distinguish between the New Deal, the Nazi regime, and Soviet central planning. Id. at 95.

190 Samuel Bowles, Alan Kirman and Rajiv Sethi, "Friedrich Hayek and the Market Algorithm", 31 J. of Econ Persp. 215 (2017).

${ }^{191}$ Milton Friedman, Capitalism and Freedom, U. of Chi. (1962) at 13. Obviously, Friedman ignores a mixed economy as an alternative type of economic organization.
} 
maximum freedom, ${ }^{192}$ and collective action by the government and labor unions threatens this freedom.

What is ignored is that the bulk of the population are forced to work for corporations, and these corporations use command and control, "the technique of its army," to deprive workers of all control over their labor. In contrast, Friedman's corporations are not collective entities, they are assumed to be equivalent to individuals. He stated that "enterprises are private so that the ultimate contracting parties are individuals." ${ }^{" 193}$ Accordingly, for Friedman any exercise of power by corporations over its employees is legitimate, while government action and the collective action of labor in response to that power is not. ${ }^{194}$ Again, the neoliberals assumed out of existence the central historical issue of the conduct of big business. ${ }^{195}$

Nancy Maclean makes a similar point in her discussion of James Buchanan's work:

The dream of this movement, its leaders will tell you is liberty. 'I want a society where nobody has power over the other,' Buchanan told an interviewer early in the new century. "I don't want to

${ }^{192}$ Id. at 15. Friedman supported his argument that collective action destroys freedom solely with examples concerning the Soviet Union, but he extended it to analyze New Deal policy. As Karl Polanyi pointed out in a famous essay, "Our Obsolete Market Mentality," 3 Commentary 109, 117 (1947), "Great Britain during the war introduced an all-round planned economy and did away with the separation of government and industry from which $19^{\text {th }}$ century freedom sprang, yet never were public liberties more securely entrenched than at the height of the emergency. In truth, we will have just as much freedom as we will desire to create and to safeguard. There is no one determinant of human society. Institutional guarantees of personal freedom are compatible with any economic system."

${ }^{193} I d$. at 14.

${ }^{194}$ Friedman was a critic of monopoly, but ultimately argued that "private unregulated monopolies were far less troubling than private monopolies regulated by the state or government operations, because they were 'generally unstable and of brief duration unless they can call government to their assistance." Angus Burgin, The Great Persuasion: Reinventing Free Markets Since the Depression, Harvard (2012) at 173.

195 Much of the work of Friedman and Hayek appears dated to modern eyes. There is a central concern with discrediting Soviet central planning. This is because the Soviet economy had grown at an average of 5.8 percent per year from 1928-1940 while the United States and most of Europe were in the throes of the Great Depression. When Germany attacked the Soviet Union in 1941 the Soviets were forced to transplant 1,523 enterprises mostly in basic industries east to escape German attack. Within two years the Soviets were out producing the Germans in tanks, aircraft and artillery. "In 1943 the gap between Soviet and German production widened further. In the middle years of the war Soviet factories produced three aircraft for every two German, and almost double the number of tanks. The balance of heavy artillery was three to one. The Soviet economy out produced the German economy throughout the war from a resource base a good deal smaller and with a workforce far less skilled." Richard Overy, Why the Allies Won, Norton (1995) at 183. 
control you and I don't want to be controlled by you.' It sounds reasonable, fair, and appealing... This cause defines the 'you' its members do not want to be controlled by as the majority of the American people. And its architects have never recognized economic power as a potential tool of domination to them, unrestrained capitalism is freedom...It would like to reinstate the kind of political economy that prevailed in America at the opening of the twentieth century, when the mass disfranchisement of voters and the legal treatment of labor unions as illegitimate enabled large corporations and wealthy individuals to dominate Congress and most state governments alike, and to feel secure that the nation's courts would not interfere with their reign. ${ }^{196}$

In sum, the founders of the neoliberal movement simply adjusted their assumptions so that "freedom" and "liberty" for all practical purposes meant only unregulated big business and the destruction of the New Deal policy regime.

Neoliberals realized that strong state action was the only way to unwind the New Deal. They believed that "its [the state's] political program will triumph only if it acknowledges that the conditions for its success must be constructed, and will not come about "naturally" in the absence of concerted effort." 197 This required that the state "guarantee the success of the market and its most important participants, modern corporations." 198 As Chicago economist George Stigler commented in 1960, the "political process is strongly biased toward collectivism.",199 Stigler suggested that one route to success would require "the restriction of the franchise to property owners, educated classes, employed persons, or some such group."200 At the 1954 meeting of the Mont Pelerin Society, James Buchanan argued that the "maintenance of [a] free

\footnotetext{
196 Nancy Maclean, Democracy in Chains: The Deep History of the Radical Right's Stealth Plan for America, Penguin (2017) at xxxiv.

197 Philip Mirowski and Dieter Plehwe, The Road From Mont Pelerin: The Making of the Neoliberal Thought Collective, Harvard (2009) at 161.

${ }^{198} I d$.

${ }^{199}$ Quoted in Quinn Slobodian, Globalists: The End of Empire and the Birth of Neoliberalism, Harvard (2018) at 237.

200 Nancy Maclean, Democracy in Chains: The Deep History of the Radical right's Stealth Plan for America, Penguin (2017) at 152 .
} 
society may well depend on the removal of certain decisions from majority-vote determination."201 Friedman followed this logic by opposing universal suffrage in Southern Africa $^{202}$ and established a long-standing relationship with the Pinochet dictatorship in Chile. ${ }^{203}$

The neoliberals of the Mont Pelerin Society and the Chicago School were joined at the hip. As Mirowski and Plehwe explain Hayek worked with Henry Simons to bring Aaron Director to Chicago and to establish the original Chicago School. ${ }^{204}$ Hayek was instrumental, along with others at the Chicago law school and the Chicago department of economics, including Milton Friedman, in securing funding for the "Free Market Study" under the direction of Aaron Director and Edward Levi. The funding came from the Volker Fund. The project strove to advance the neoliberal project into new areas of policy. The "Antitrust Project" followed The Free Market Study and ran from 1953 to 1957 . The project developed the basic Chicago School analysis of antitrust law. The Antitrust Project included work by Aaron Director, Edward Levi, John McGee, Ward Bowman, and Robert Bork. ${ }^{205}$ This effort's later expansion included a program in law and economics, and research fellowships were granted to Ronald Coase and

\footnotetext{
${ }^{201}$ Angus Burgin, The Great Persuasion: Reinventing Free Markets since the Depression, Harvard (2012) at 118.

202 Quinn Slobodian, Globalists: The End of Empire and the Birth of Neoliberalism, Harvard (2018) at 151.Slobodian shows how the neoliberals sought to establish world political federations that could protect international free trade from domestic political democracies.

${ }^{203}$ In March 1975 Milton Friedman and Arnold Harberger flew to Santiago. According to Naomi Klein "Friedman hammered at a single theme: the junta was off to a good start, but it needed to embrace the free market with greater abandon." Klein further documented the relationships that were built between the Chicago economics department and several military dictatorships in Latin America. Naomi Klein, The Shock Doctrine: The rise of disaster capitalism," Picador (2007) at 98 and Chapter 4. Nancy McLean discussed how James Buchanan helped the Pinochet regime draft its constitution, which limited democracy and insured Pinochet's power. See Nancy Maclean, Democracy in Chains: The Deep History of the Radical right's Stealth Plan for America, Penguin (2017) Chapter 10.

${ }^{204}$ Philip Mirowski and Dieter Plehwe, The road from Mont Pelerin: The Making of the Neoliberal Thought Collective, Harvard (2009) at 158-163.

${ }^{205}$ Ron Van Horn, "Reinventing Monopoly and the Role of Corporations: The Roots of Chicago Law and Economics" in Philip Mirowski and Dieter Plehwe ed. The Road from Mont Pelerin: The Making of the Neoliberal Thought Collective, Harvard U.P. (2009) at 221
} 
Richard Posner. ${ }^{206}$ The subsequent Chicago School "research program" produced a massive number of papers all of which questioned the premises of the New Deal antitrust policy regime. ${ }^{207}$

In their 1956 article, Aaron Director and Edward Levi discussed the emerging views of the Chicago School of economics on the antitrust law. ${ }^{208}$ They plainly stated their main point: "We believe the conclusions of economics do not justify the application of the antitrust laws in many situations in which the laws are now being applied." 209 Critically, Director and Levi asserted "the act [Sherman Act] arose out of an antipathy towards monopoly, and those restraints which were thought to have consequences of monopoly. And it is in the identification and the prediction of the consequences of monopoly that economics has the most to contribute."210 Thus, according to the authors, only mergers to monopoly and price-fixing cartels were legitimate objects of antitrust scrutiny. Director and Levi doubted that any single firm actually could exercise true monopoly power. "It is much less common than it was [earlier in time] to have an industry in which one firm has seventy or more percent control over productive capacity or sales." 211 Abusive conduct such as vertical integration, tying price discrimination, resale price maintenance, and exclusionary conduct should not come under antitrust scrutiny because "economic teaching gives little support to the idea that the abuses create or extend monopoly.",12 Thus, Director and Levi redefined the goals and purview of antitrust enforcement, and called for

\footnotetext{
${ }^{206} I d$. at 230.

207 The authors included Yale Brozen, Harold Demsetz, John McGee, Gary Becker, Sam Peltzman, Milton Friedman, Richard Posner, Robert Bork, Lester Telser and several others.

${ }^{208}$ Aaron Director and Edward Levi, "Law and the Future: Trade Regulation," 51 Nw. U.L. Rev. 281 (1956-1957).

${ }^{209} I$ d. at 282.

${ }^{210} I d$. at 287.

${ }^{211} I d$. at 284 .

${ }^{212} I d$. at 290 .
} 
a radically scaled back antitrust regime, which presaged the more detailed reconsideration of antitrust put forward by Robert Bork and Richard Posner.

By the late 1970s, the Chicago School had a well-developed antitrust policy program wherein the only legitimate goal of antitrust enforcement is to prevent price increases that result from excessive market power. Often referred to as the "consumer welfare" standard, Robert Bork coined this term and argued for "exclusive adherence" to its standard. ${ }^{213}$ The Chicago School contended that horizontal conspiracies did not require significant enforcement resources because they believed cartels to be unstable with a tendency to self- destruct because of the strong incentive to cheat. ${ }^{214}$ In their view mergers, particularly mergers that are not to monopoly, are usually efficiency increasing, and undertaken for that purpose. ${ }^{215}$ They argued that predatory pricing is an irrational business strategy because the predator loses money during the predation stage, and "if he tries to recoup it later by raising his price, new entrants will be attracted."216 Only under very specific conditions does a tying arrangement raise antitrust concerns. $^{217}$ The logic is that firms face a reservation price on the bundle of tied goods, and have the option of raising the price of the tying product in order to obtain any available rents. Consequently, tying is not a profitable strategy unless it results in efficiencies. ${ }^{218}$ Resale price

\footnotetext{
${ }^{213}$ Herbert Hovenkamp, “Antitrust Policy after Chicago,” 82 Mich. L. Rev 213, 226 (1985); Robert Bork, The Antitrust Paradox: A Policy at War with Itself, Basic (1978) at 81; Richard Posner, Antitrust Law: An Economic Perspective, U of Chi. (1976) at 13;

${ }^{214}$ George Stigler, "A Theory of Oligopoly” 72 J. of Pol. Econ. 44, 46 (1964)

${ }^{215}$ Frank Easterbrook, "Limits of Antitrust," 63 Tex. L. Rev. 1, 3 (1984); Robert Bork, The Antitrust Paradox: A Policy at War with Itself, Basic (1978) at 221.

${ }^{216}$ Richard Posner, “The Chicago School of Antitrust Analysis,” 127 U of Penn. L. Rev 926, 927 (1979).

${ }^{217}$ A tie only presents a problem when there is a regulatory constraint on the price of the tying product. Robert Bork, The Antitrust Paradox: A Policy at War with Itself, Basic (1978) at 376.

${ }^{218}$ Robert Bork, The Antitrust Paradox: A Policy at War with Itself, Basic (1978) at 372-381; Richard Posner, Antitrust Law: An Economic Perspective, U of Chi. (1976) at 171-184.
} 
maintenance and non-price vertical restraints are also efficiency producing because they were necessary for the provision of presale dealer services. ${ }^{219}$ Nor does vertical integration present an antitrust concern. The concern raised by a vertical merger is the foreclosure, or inability of a competitor to gain access to vendors or distributors. According to the Chicago School, this scenario would not happen. Vertical mergers merely realigned trading parties and do not cause foreclosure. $^{220}$ Moreover, vertical integration usually involved efficiencies such as the elimination of the double marginalization problem and the elimination of transactions costs from contracting. $^{221}$ In sum, little to no antitrust enforcement was warranted. They maintained that big business seeks efficiencies, which benefit the economy as whole, and the previous antitrust policy had been harmful and unwarranted. In the crisis of the 1970s, the Courts would implement the minimalist Chicago School program.

\section{The Crisis of the 1970s}

Figure 1 demonstrates a virulent fall in the rate of profit in the United States beginning in 1966. Ferguson and Rogers argue that 1966 also marked the beginning of the decline of the New Deal political coalition. $^{222}$ In the 1970 s, the American economy plunged headlong into a crisis that visited significant pain upon individuals at all income levels. ${ }^{223}$ Critical for the narrative here is the pressure that the crisis of the 1970s placed on high income recipients and businesses.

\footnotetext{
${ }^{219}$ Ward Bowman, "Resale Price Maintenance - Monopoly Problem." 25 J. of Bus. 141 (1952); Lester Telser, "Why Should Manufacturers Want Fair Trade?" 3 J. of Law and Econ 86 (1960); Richard Posner, "The rule of Reason and the Economic Approach, Reflections on the Sylvania Decision," 45 U. of Chicago L. Rev. 6 (1977). Many of the points made by the Chicago School appeared earlier in Basel S. Yamey, The Economics of Resale Price Maintenance, pub. (1954).

${ }^{220}$ Robert Bork, "Vertical Integration and the Sherman Act: The Legal History of an Economic Misconception," 22 Univ. of Chi. L. Rev 157 (1954); Robert Bork The Antitrust Paradox, Basic Books (1978) at 228.

${ }^{221}$ Dennis Carlton and Jeffrey Perloff, Modern Industrial Organization, Harper Collins (1994) at 501-520.

222 Thomas Ferguson and Joel Rogers, Right Turn: The Decline of the Democrats and the Future of American Politics, Hill and Wang (1986) at 78-83 and discussion with Thomas Ferguson.

${ }^{223}$ Id at 80 .
} 
This pressure accelerated the conservative political counter attack on the New Deal policies that had begun earlier. ${ }^{224}$ Among the goals of the counter attack were the removal of all barriers to increases in income and wealth, the cessation of regulation of the financial sector, dilution of the power of unions, and the hobbling of antitrust enforcement. The well-funded conservative organizations that emerged to implement this program were pivotal to the rise to policy dominance of the Chicago School. ${ }^{225}$

\section{a. Economic Performance in the Crisis of the 1970s}

The 1970s were a period of significant crisis in the United States. The initial fall in the rate of profit in 1966 was a result of competition from Japan and Germany. By the late 1960s, the German and Japanese economies had recovered from World War II and successfully challenged the U.S. in several major industries including consumer electronics, automobiles, steel, petrochemicals and other industries. However, there were also other factors at play. Another problem was that the economy appeared to have exhausted the limits of the technologies such as electrification that had undergirded the great leap forward and the golden age of capitalism. ${ }^{226}$ As a consequence, the growth of productivity declined sharply in the 1970s. Robert Gordon calculated that total factor productivity on average between 1920 and 1970 was 1.89 , but from 1970 to 1994 , the rate of total factor productivity growth dropped to 0.57 . At the height of the New Deal total factor productivity had reached 3.0. Additional factors also contributed to the decline including the two OPEC oil shocks. Ferguson and Rogers describe the

\footnotetext{
${ }^{224}$ John Saloma, Ominous Politics: The New Conservative Labyrinth, Hill and Wang (1984) (recounting the history of conservative think tanks, political action groups, religious broadcasters, and corporate political organizations).

${ }^{225}$ Nancy MacLean, Democracy in Chains: The Deep History of the Radical Right's Stealth Plan for America, Penguin (2017) at 121-122; John Saloma, Ominous Politics: The New Conservative Labyrinth, Hill and Wang (1984) at 75; Thomas Ferguson and Joel Rogers, Right Turn: The Decline of the Democrats and the Future of American Politics, Hill and Wang (1986) at 87.

${ }^{226}$ Robert Gordon, The Rise and Fall of American Growth: The U.S. Standard of Living Since the Civil War, Princeton (2016) at 566-567.
} 
1973 rise in oil prices as "one of world history's truly momentous events." ${ }^{227}$ Because of all of these factors, the profit rate for corporations and other firms dropped significantly from a high in 1966 to an historical low point in the 1973 recession. The average profit rate for the decade of the 1970s was 7.9 percent, a significant reduction from the 1950s and 1960s. The unemployment rate in the 1970 s grew to an average of $6.22 \%$ per year $^{228}$ and inflation exploded to an average $7.09 \%$ per year. These were truly crisis level statistics.

b. The Impact of the Crisis on the Incomes of the Wealthy and the Political Backlash

The economic crisis of the 1970s harmed every sector of the economy, but particularly affected financial corporations and high-income individuals. Corporate profits fell significantly while the stock market flatlined. ${ }^{229}$ Growing inflation resulted in low real interest rates, near zero in 1971 and negative in 1975, which were detrimental in the financial sector. The average real interest rate between 1971 and 1978 was only 1.2\%. The profits of financial corporations suffered as evidenced by their greater profit decline relative to corporations outside the financial sector. $^{230}$ Finally, the 1970 s saw the income share of the top $1 \%$ of earners reach a post-WWII low. $^{231}$

The economic situation facing corporations, finance and the wealthy sparked a major political backlash. The backlash took many forms but included what John Saloma referred to as the conservative labyrinth of well-funded conservative think tanks, corporate groups and other

\footnotetext{
227 Thomas Ferguson and Joel Rogers, Right Turn: The Decline of the Democrats and the Future of American Politics, Hill and Wang (1986) at 89.

${ }^{228}$ Id.

${ }^{229}$ Gérard Duménil and Dominique Levy, The Crisis of Neoliberalism, Harvard U.P. (2011) at 64.

${ }^{230}$ Gérard Duménil and Dominique Levy, The Crisis of Neoliberalism, Harvard U.P. (2011) at 67.

${ }^{231}$ Timothy Noah, The Great Divergence, Bloombury (2012) at 24.
} 
organizations that grew in size and influence in the 1970s. ${ }^{232}$ Emblematic of this revolt was the 1971 memo sent to the U.S. Chamber of Commerce titled "Attack on American Free Enterprise System" by future Supreme Court Justice Lewis Powell. The Powell memo "is widely cited as the beginning of the corporate mobilization to transform American law and politics."233 Powell called for businesses to organize, plan and understand the importance of political power to their economic interests. According to Peter Temin, Charles Koch "was galvanized by the Powell Memo and formed the Cato Institute," an organization focused on the proliferation of free market ideas among academics. ${ }^{234}$ As described by Jacob Hacker and Paul Pierson, the ensuing counterattack of business was "a domestic version of Shock and Awe". ${ }^{235}$ Hacker and Pierson describe the situation:

The number of corporations with public affairs offices in Washington grew from 100 in 1968 to over 500 in 1978. In 1971, only 175 firms had registered lobbyists in Washington, but by 1982, nearly $2500 \mathrm{did}$. The number of corporate PACs increased from under 300 in 1976 to over 1200 by the middle of $1980 \ldots{ }^{236}$

Conservative think tanks were both established and expanded. The Business Roundtable was founded in $1972 .^{237}$ The Heritage Foundation was established in $1973 .^{238}$ Other conservative organizations included the John M. Olin Foundation, the Scaife Foundations, the Lynde and Harry Bradley Foundation, the American Enterprise Institute, the Institute for Contemporary

\footnotetext{
232 John Saloma, Ominous Politics: The New Conservative Labyrinth, Hill and Wang (1984) at 7.

${ }^{233}$ Nancy MacLean, Democracy in Chains: The Deep History of the Radical Right's Stealth Plan for America, Penguin (2017) at 125.

${ }^{234}$ Peter Temin, The Vanishing Middle Class Prejudice and Power in a Dual Economy, MIT (2017) at 18. In 1973 the Koch Brothers also formed the American Legislative Exchange Council to advance conservative principles in state legislation. According to Temin, "around one-fifth of its proposed legislation [got] passed somewhere in the country". Id. at 19.

${ }^{235}$ Quoted in Alan Nassar, Overripe Economy American Capitalism and the Crisis of Democracy, Pluto Press (2018) at 155.

${ }^{236} \mathrm{Id}$.

${ }^{237}$ John Saloma, Ominous Politics: The New Conservative Labyrinth, Hill and Wang (1984) at 66-67.

${ }^{238}$ Id at $14-19$.
} 
Studies, the Hoover Institute ${ }^{239}$, and others. As Roger E. Backhouse argued, these foundations were successful because they focused on a small group of conservative academics promoting neoliberal ideas including Law and Economics at Chicago and Public Choice at the University of Virginia and George Mason University. ${ }^{240}$ Such organizations sponsored Chicago School research, promoted their theories and findings, and recruited promising new members to their cause.

\section{The Age of Neoliberalism}

The neoliberal political movement was remarkably successful. The policy transformation began in the Carter administration with the effort to deregulate airlines via The Airlines Deregulation Act of 1978, and trucking and railroad transportation via The Staggers Rail and Motor Carrier Act of 1980. Carter appointed Paul Volker to head the Federal Reserve in 1979. The Volker-induced high interest rates propagated a flow of capital into U.S., which strengthened the value of the dollar. The high dollar crippled export sales, which devastated manufacturing, a key union stronghold. As a result, union workers fell from 23 percent of the working population in 1979 to 16 percent by $1985 .^{241}$

The state became openly hostile to labor with the election of Ronald Reagan. ${ }^{242}$ Early in his administration, the air traffic controllers went on strike. Reagan's responded by firing the entire workforce and replacing them with scab labor. In addition, Reagan also appointed Donald

\footnotetext{
${ }^{239}$ According to John L Kelley, "50 of the Hoover's scholars or fellows ... served in some capacity in the Reagan administration by 1985 .

${ }^{240}$ Roger E. Backhouse, "Economists and the rise of neo-liberalism” 117 Renewal 17 (2009).

${ }^{241}$ Frank Levy and Peter Temin, Inequality and Institutions in $20^{\text {th }}$ Century America, NBER (2007) at 34-35.

${ }^{242} I d$. at $31-33$.
} 
Dotson, a former management labor consultant, to chair the National Labor Relations Board. ${ }^{243}$

Dotson oversaw "a succession of rulings that gave management greater leeway to interrogate and fire union supporters and to make misleading statements during union elections."244 These rulings and other measures described below significantly eroded union strength and ultimately resulted in a continued decline in union membership in the United States. By 2013 only $11.3 \%$ of the workforce belonged to a union. ${ }^{245}$ Under the Reagan administration and subsequent presidents Congress further allowed the real federal minimum wage to decline. In 2015 dollars, the minimum wage was $\$ 9.44$ in 1980 . In 1990 , the minimum wage had eroded to $\$ 6.87 .^{246}$ The clear aim of the neoliberal policies was to restore profits and high incomes.

\section{a. The Success of the Chicago School Antitrust Program}

The first significant Chicago School antitrust success at the Supreme Court was Continental T.V. Inc. v. GTE Sylvania Inc, 433 U.S. 36 (1977). There, Louis Powell (of memo fame), writing for the 6-2 majority, held that non-price vertical restraints warrant only rule of reason analysis. As a result, vertical exclusive customer and territory restrictions became very difficult to challenge. The standard for proving vertical conspiracies was also elevated in Monsanto Co. v. Spray-Rite Service Corp., 465 U.S. 752 (1984), and the per se rule against Resale Price Maintenance slowly eroded away until it was finally eliminated in Leegin Creative Leather Products v. PSKS, Inc., 551 U.S. 877 (2007).

\footnotetext{
243 Thomas Ferguson and Joel Rogers, Right Turn: The Decline of the Democrats and the Future of American Politics, Hill and Wang (1986) at 130-137 (describing the Reagan administration's deregulation efforts and its attack on labor).

244 Timothy Noah, The Great Divergence: America's Growing Inequality Crisis and What we can do about it, Bloomsbury (2012) at 142.

245 Megan Dunn and James Walker, “Union Membership in the United States,” BLS September 2016.

246 David Card and John E. DiNardo "Skill-Biased Technical Change and Rising Inequality: some Problems and Puzzles", 20 J. of Labor Econ 773, 774-776 (2002); John DiNardo, Nicole Fortin and Thomas Lemieux, "Labor Market Institutions and the Distribution of Wages 1973-1992: A Semiparametric Approach" 64 Econometrica 1001 (1996); David Lee, "Wage Inequality in the United States During the 1980s: Rising Dispersion or Falling Minimum Wage?” 114 Q. J. of Econ 997 (1999).
} 
In the late 1970s and the 1980s, the Court began to carve out exceptions to the per se rule against horizontal price fixing. The GTE Sylvania decision had signaled that a "demanding standard" should be applied before the per se rule should be applied. ${ }^{247}$ In Broadcast Music, Inc. v. Columbia Broadcasting System, Inc., 441 U.S. 99 (1979) the court carved out the exception for situations where horizontal coordination was plausibly needed in order to offer a "new product." In National Collegiate Athletic Association v. Board of Regents of University of Oklahoma, 468 U.S. 85 (1984), the Court found the NCAA came within the new product exception to the per se rule. I do not mean to suggest that BMI and Board of Regents were purely the result of the influence of the Chicago School. While the Chicago School contended that cartels were unstable and less worrisome than earlier thought, there were legitimate limits to the application of the Socony Vacuum approach. For instance, integrated entities, like firms and partnerships could not reasonably be subject to the per se rule. However, the Chicago School swayed the Courts to make exceptions even for more loosely integrated structures like the NCAA. ${ }^{248}$ The Chicago School's skepticism about cartel stability also contributed to the higher burden that emerged for proof of conspiracy in Matsushita Electric Industrial Co. v. Zenith Radio Corp., 475 U.S. 574 (1986) and Bell Atlantic Corp. v. Twombly, 550 U.S. 544 (2007).

The Chicago School influence also led to a more permissive approach to mergers. In United States v. General Dynamics Corp., 415 U.S. 486 (1974), the Court rejected the Department of Justice's reliance on market shares challenging the assumption that they reflected future competitive significance. Extending the departure from earlier precedent, lower courts

\footnotetext{
${ }^{247}$ FTC v. Ind. Fed'n of Dentists, 476 U.S. 447, 458-59 (1986) ("we have been slow ... to extend per se analysis to restraints imposed in the context of business relationships where the economic impact of certain practices is not immediately obvious").

${ }^{248}$ Indeed, the Supreme Court cited to Robert Bork's Antitrust Paradox in noting that ""[S]ome activities can only be carried out jointly. Perhaps the leading example is league sports. When a league of professional lacrosse teams is formed, it would be pointless to declare their cooperation illegal on the ground that there are no other professional lacrosse teams." R. Bork, The Antitrust Paradox 278) (1978), 486 U.S. at 85.
} 
also engineered several defenses to a merger challenge. In United States v. Syufy Enterprises, 903 F.2d 659 ( $9^{\text {th }}$ Cir. 1990), the Ninth Circuit allowed a merger with high market shares because of evidence of easy entry, as did the D.C. Circuit in United States v. Baker Hughes Inc., 908 F.2d 981 (D.C. Cir. 1990). Then, in Federal Trade Commission v. University Health, Inc., 938 F.2d $1206\left(11^{\text {th }}\right.$ Cir. 1991) the Eleventh Circuit held that evidence of substantial efficiencies can be used to rebut evidence of higher concentration.

Since 1982, the various versions of the Horizontal Merger Guidelines published by the DOJ and FTC weakened earlier agency merger enforcement. ${ }^{249}$ The current 2010 Horizontal Merger Guidelines requires much more than the original structural presumptions mandated by the Court in the Brown Shoe and Philadelphia Bank cases. Instead, the Guidelines require that the agencies develop and prove an anticompetitive scenario that would likely result from the proposed merger. Even if that exacting hurdle is met, a showing of easy entry or possibly significant efficiencies can still defeat the case for the merger challenge.

Finally, the Chicago School completely eviscerated any FTC or DOJ interest in enforcing the Robinson-Patman Act, despite the fact that both Congress and the Courts have resisted the wholesale abandonment of that law. While the Robinson-Patman is still viable, the Courts have whittled away at the Morton Salt approach, making the burden for meeting the cost justification defense lighter, while rendering the element of competitive injury (and antitrust injury for private plaintiffs) much more difficult.

\section{1. $\quad$ Higher Concentration and Higher Profits}

Recently, there has been an enormous outpouring of analysis and data questioning the effectiveness of antitrust enforcement under the sway of Chicago School principles. This

\footnotetext{
${ }^{249}$ Guidelines were issued by the DOJ in 1982 and 1984 and by the FTC in 1982 . In 1992 the FTC and the DOJ jointly issued Horizontal Merger Guidelines. These were revised in 1997 (regarding efficiencies) and then again in 2010 .
} 
literature is broad in nature, including the popular press, ${ }^{250}$ economics journals, ${ }^{251}$ policy institute papers, ${ }^{252}$ and law reviews. ${ }^{253}$ The literature indicates a consensus that market concentration in the United States has grown significantly since the 1990s. However, rising concentration does not conclusively demonstrate an increase in market power because national concentration data assumes national geographic markets and product categories that may not be coextensive with product markets. However, concentration does show that big business has grown in size. ${ }^{254}$ In addition, anecdotal evidence suggests that market power has increased. As a representative sample of this literature, Jonathan Tepper and Denise Hearn observed that today just three companies control the nation's cable market. Microsoft still has a $90 \%$ share in computer operating systems. Facebook has $75 \%$ of the global social media market, and Google has $90 \%$ of search advertising. Moreover, a small number of big firms control many industries: milk,

${ }^{250}$ Francis, T. and Knutson, R., "Wave of megadeals tests antitrust limits in U.S." The Wall Street Journal. October 18, 2015; The Economist, March 26, 2016, "Too Much of a Good Thing;" Mitchel, S, "The rise and fall of the word 'monopoly' in American life". June 20, 2017; See citations in Carl Shapiro, "Antitrust in a Time of Populism" 61 Int. J. of Ind. Org. 714 (2018).

${ }^{251}$ Autor, D., Dorn, D., Katz, L. F., Patterson, C. and van Reenen, J. "Concentrating on the Fall of the Labor Share". 107 Amer. Econ. Rev.180 (2017); Grullon, G., Larkin, Y. and Michaely, R. "Are U.S. industries becoming more concentrated?" 2017 Working Paper. Gutierrez, G. and Philippon, T. "Declining competition and investment in the U.S.” NBER Working Paper No. 23583 (2017).

${ }^{252}$ Baker, J. "Market power in the U.S. economy today", 2017 report, Washington Center for Equitable Growth; Council of Economic Advisers, "Benefits of competition and indicators of market power". Council of Economic Advisers Issue Brief. April 2016; Jarsulic, M., Gurwitz, E., Bahn, K., and Green, A. "Reviving antitrust. Why our economy needs a progressive competition policy". Center for American Progress (2016); Jarsulic, M., Gurwitz, E., Bahn, K., and Green, A. "Reviving antitrust. Why our economy needs a progressive competition policy". Center for American Progress (2016); Shambaugh, J., Nunn, R., Breitwieser, A. and Liu, P., "The state of competition and dynamism: Facts about concentration, start-ups, and related policies". The Hamilton Project. Economic Facts. June 2018; Steinbaum, M.; Bernstein, E. and Sturn, J. "Powerless: How lax antitrust and concentrated market power rig the economy against American workers, consumers, and communities." The Roosevelt Institute (2018); Marshall Steinbaum and Maurice Stucke, "The Effective competition Standard: A New Standard for Antitrust," Roosevelt Institute (2018).

253 Daniel Crane,“Antitrust's unconventional politics”. 104 Virginia Law Review Online 118 (2018); Lina Kahn, “Amazon's Antitrust Paradox,” 126 Yale L.J. 564 (2016-2017); Sadeep Vaheesan, "The twilight of the technocrats' monopoly on antitrust?" 127 Yale L. J. 980 (2018).

${ }^{254}$ Two good summaries of this literature are: Carl Shapiro, "Antitrust in a Time of Populism” 61 Int. J. of Ind. Org. 714 (2018), and International Monetary Fund, World Economic Outlook, April 2019, Chapter 2. 
modified seed, microprocessors, airlines, health insurance, medical care, group purchasing organizations, drugs, meat and poultry, agriculture, media, title insurance, and other industries. ${ }^{255}$

A second major result of lax antitrust enforcement is that the mark-ups, and therefore profit margins, of these large firms has increased. In their widely-cited NBER paper, De Loecker and Eeckhout found, for example, that firm level markups have increased from $18 \%$ to $67 \%$ since $1980 .^{256}$ Numerous studies have come to similar conclusions. ${ }^{257}$ Many factors influence profits, and market power can be a key influence. Market power can cause differential profits between firms. Market power in consumer goods industries can lower real wages and can increase profits system wide. $^{258}$

\section{The Post Chicago School of Antitrust}

The Chicago School has not gone unchallenged in the neoliberal era. Beginning in the 1990s a group of less conservative economists engaged in theoretical and empirical industrial organization analysis took issue with many of the key premises of the Chicago School. As Tim Wu described in his recent book:

The Chicago movement, unsurprisingly, began to encounter major resistance during the 1980s through the 2000s. A group of economists and other academics, styled the "post-Chicago" school, emerged to challenge many of its basic premises. What the post-

\footnotetext{
255 Jonathan Tepper and Denise Hearn, The Myth of Capitalism, Wiley (2019), Chapter 6.

${ }^{256}$ Reported in Marshall Steinbaum, Eric Harris Bernstein, and John Sturm, "Powerless: How Law Antitrust and Concentrated Market Power Rig the Economy Against American workers, Consumers, and Communities" Roosevelt Institute, February 2018 at 18.

${ }^{257}$ Marc Jarsulic, Ethan Gurwitz, Kate Bahn and Andy Green, "Reviving Antitrust: Why our Economy Needs a Progressive Competition Policy," Center for American Progress, June 2016 at 5 (after tax corporate profits have risen since 2000); Gauti Eggertsson, Jacob Robins and Ella Getz Wold, "Kaldor and Piketty's Facts: The Rise of Monopoly Power in the United States," Washington Center for Equitable Growth, February 2018 at 4 (showing "a large increase in markups over the past forty years”); Carl Shapiro, "Antitrust in a Time of Populism,” 61 Int. J. of Ind. Org. 714, 733 ("these data strongly suggest that U.S. corporations really are systematically earning far higher profits than they were 25 or 30 years ago.")

${ }^{258}$ In the history of economics field this is known as the theory of profit on alienation. System wide, if every firm raises the mark up what one firm gains as a seller it loses as a buyer. The exception is if workers cannot raise money wages then their real wage declines and this could result in higher profits system wide.
} 
Chicago academics demonstrated was this. Even if you took a strictly economic view of the antitrust laws, you didn't actually reach Bork's conclusions. ${ }^{259}$

The post-Chicago school has undermined most of the intellectual basis for the original Chicago School policy prescriptions. For example, post-Chicago economists have shown that cartels can be stable. $^{260}$ Moreover, entry barriers can exist and can slow or deter entry into uncompetitive markets. $^{261}$ Post-Chicago school commentators also are less sanguine about merger efficiencies, but continue to believe that efficiencies are a relevant factor in merger analysis. $^{262}$ Post-Chicago analysis has shown that predatory pricing can be a rational and successful business strategy. ${ }^{263}$ Tying arrangements can harm competition by raising barriers to entry. ${ }^{264}$ Certain bundling strategies can also increase total profits by reducing competition in the tied market. ${ }^{265}$ Some post-Chicago economists have challenged the core Chicago School

\footnotetext{
${ }^{259}$ Tim Wu, The Curse of Bigness: Antitrust in the New Gilded Age, Columbia (2018) at 107.

${ }^{260}$ The "Folk Theorem" shows that in an infinite repeated game a cartel can be a subgame perfect Nash equilibrium. This means that it can be fully stable. A clear explanation with the relevant references can be found in Jean Tirole, The Theory of Industrial Organization, MIT (1989) at § 6.3; Jonathan Baker, "Recent Developments in Economics that Challenge Chicago School Views," 58 Antitrust L. J. 645, 649-650 (1989).

${ }^{261}$ Steven Salop, "Measuring Ease of Entry," 31 Antitrust Bull. 551 (1986) (stressing the role of minimum efficient scale and sunk costs).

${ }^{262}$ Jon Baker and Carl Shapiro, "Reinvigorating Horizontal Merger Enforcement", U.C. Berkeley working paper, April 10, 2007 at 26.

${ }^{263}$ First, victims may not be able to obtain finance during the predation stage because capital markets are not entirely efficient. A bank manager may not know, for example, whether the victim's low profits are due to predation or bad management, and there may not be a credible way for the victim to signal good management to the bank. Second, predation against several rivals can create a reputation for irrational aggressiveness that can deter entry or cause potential victims in other markets to cooperate. Thus, recoupment can occur in markets other than where the predation occurred. Migrom \& Roberts, "Predation, Reputation and Entry Deterrence," 27 J. Econ Theory 280 (1982); Jon Baker, "Predatory Pricing After Brooke Group: An Economic Perspective," 62 Antitrust L.J. 585 (1994).

${ }^{264}$ Barry Nalebuff, "Bundling," Yale ICF Working Paper No. 99-14 (November 22, 1999) (showing that tying can control entry and the gains from entry deterrence are much greater than the gains from price discrimination).

265 Michael Whinston, "Tying Foreclosure, and Exclusion.” 58 Am. Econ. Rev. 837 (1990); Barry Nalebuff, "Bundling as a Way to Leverage Monopoly," Yale School of Management Working Paper \# 36, (October 1, 2004).
} 
analysis of resale price maintenance. ${ }^{266}$ But other post-Chicago economists have also offered alternative theories, not based on post sale service, to justify resale price maintenance. ${ }^{267}$ Several economists have shown that profitable vertical integration can cause foreclosure. ${ }^{268}$ Vertical integration can also harm competition. ${ }^{269}$ Finally, it has been demonstrated that there are limitations to achieving efficiencies from eliminating double marginalization. ${ }^{270}$

Generally, the post-Chicago economists have favored stronger antitrust enforcement ${ }^{271}$ though their influence has been limited. While these economists have helped to mold agency policy, courts have been stubbornly resistant to abandoning Chicago School principles. For example, in Verizon Communications v. Law Offices of Curtis V. Trinko, 540 U.S. 398 (2004) the Supreme Court stated, "the opportunity to charge monopoly prices - at least for a short period - is what attracts business acumen" and leads to "innovation and economic growth."

\footnotetext{
${ }^{266}$ However, cases where resale price maintenance does not increase efficiency are possible. Derek Scherer, "The Economics of Vertical Restraints," 52 Antitrust L. J. 687 (1983); Robert Steiner, "Vertical Restraints and Economic Efficiency," FTC working paper no. 66 (June 1982). Many cases of resale price maintenance do not involve presale services. Sharon Oster, "Levi Strauss," 19 J. Reprints Antitrust L. \& Econ. 47 (1989); Robert Pitofsky, "Are Retailers Who Offer Discounts Really 'Knaves'?: The Coming Challenge to the Dr. Miles Rule,” 2007 Antitrust 61.

${ }^{267}$ Howard Marvel and Stephen McCafferty, "Resale Price Maintenance and Quality Certification" 15 Rand J. of Econ. 346 (1985). Roger Blair and David Kaserman, Antitrust Economics, $2^{\text {nd }}$ Ed., Oxford (2009) at 378. However, little empirical evidence exists to justify any of these theories, and if some consumers desire these benefits but others don't the overall impact can be ambiguous. William S. Comanor, "Vertical Price-Fixing, Vertical Market Restrictions, and the New Antitrust Policy," 98 Harvard L. Rev. 983 (1985); Benjamin Klein, "Competitive Resale Price Maintenance in the Absence of Free-Riding," 76 Antitrust L. J. 431, 433 (2009). Warren Grimes argued that Resale Price Maintenance can harm consumers in two ways: (1) maintaining high manufacturer margins and (2) by promoting premium brands that are not superior products. Warren Grimes, "A Dynamic Analysis of Resale Price Maintenance: Inefficient Brand Promotion, Higher Margins, Distorted Choices, and Retarded Retailer Innovation," 55 Antitrust Bull. 101 (2010).

${ }^{268}$ Michael Salinger, "Vertical Mergers and Market Foreclosure," 103 QJE d345 (1988); see citations in Steven Salop, "Invigorating Vertical Merger Enforcement" 127 Yale L. J. 1962, 1966 (2018) at n. 17.

${ }^{269}$ Non-integrated firms may face distributors with augmented market power or higher costs. This can lead to higher prices, which allow the vertically integrated producer to raise its prices. Krattenmaker and Steven Salop, "Anticompetitive Exclusion: Raising Rivals' Costs to Achieve Power over Price," 96 Yale L. J. 209 (1986); Jon Baker, "Recent Developments in Economics that Challenge Chicago School Views," 58 Antitrust L.J. 645, 647 (1989).

${ }^{270}$ Steven Salop, “Invigorating Vertical Merger Enforcement,” 127 Yale L. J. 1962, 1970-1971 (2018).

${ }^{271}$ Jon Baker, "Market Power in the U.S. Economy Today," Washington Center for Equitable Growth (date); Jon Baker, "The Case for Antitrust Enforcement," 17 J. Econ. Persp. 27 (2003); Steven Salop and Carl Shapiro, "Wither Antitrust Enforcement in the Trump Administration," Antitrust Source (2017).
} 
There is little empirical evidence to support this supposition. The Court's opinion is merely Chicago School conjecture. ${ }^{272}$

In Brooke Group Ltd v. Brown \& Williamson Tobacco Corp., 509 U.S. 209 (1993), the Supreme Court heightened the burden for demonstrating predatory pricing, while ignoring the post-Chicago school theories of recoupment. ${ }^{273}$ In Leegin Creative Leather Products, Inc. $v$. PSKS, Inc., 551 U.S. 877 (2007), the Supreme Court overturned one hundred years of precedent to hold that resale price maintenance was no longer per se illegal and that the rule of reason would apply. ${ }^{274}$ The majority accepted the Chicago School presumptions without factual confirmation. The only case in which the post-Chicago school analysis arguably prevailed over the Chicago School at the Supreme Court appears to be Eastman Kodak Co. v. Image Technical Services, Inc., 504 U.S. 451 (1992). ${ }^{275}$

\section{a. Higher Profits and Income from Globalization}

Quinn Slobodian describes how a central tenet of the neoliberal agenda was free trade and globalization. ${ }^{276}$ Indeed, neoliberal economists had earlier pushed for an elimination of capital controls. The United States and most European countries lifted capital controls in the

\footnotetext{
272 Maurice Stucke, "Should we Be Concerned About Data-opolies?" 2 Geo. L. Tech. Rev. 275, 303-304 (2018)(showing refusals to deal by a dominant firm can reduce innovation).

${ }^{273}$ Jonathan B. Baker, "Predatory Pricing after Brooke Group: An Economic Perspective," 62 Antitrust L. J. 585 (1994).

${ }^{274}$ The majority opinion largely recounted the Chicago School claims about the efficiencies that can be derived from controlling free riders in retail using resale price maintenance. In his dissent, Judge Breyer identified the weakness in the Chicago School argument. He asked "How often, for example, will the benefits to which the Court points occur in practice? I can find no economic consensus on this point...All this is to say that the ultimate question is not whether, but how much, "free riding" of this sort takes place..."

${ }^{275}$ In that case the Court rejected Kodak's proposition that as a matter of law competition in the equipment market for copy machines would protect Kodak's installed base from all possible exploitation by Kodak. The Court rejected the presumption stating that "[1]egal presumptions that rest on formalistic distinctions rather than actual market realities are generally disfavored in antitrust law."

${ }^{276}$ Quinn Slobodian, Globalists: The End of Empire and the Birth of Neoliberalism, Harvard (2018).
} 
1970s, and many developing countries eliminated capital controls in the 1980s and 1990s. ${ }^{277}$ The result of liberalized trade and capital movements for the United States has been a rise of investment by U.S. companies abroad, and an increase in corporate profits extracted from the rest of the world. ${ }^{278}$

This investment abroad primarily involved a shift of manufacturing activity from industrialized countries to developing countries, with a significant number of U.S. companies moving off shore. ${ }^{279}$ U.S. multinational firms then exported much of this production back to the United States. The incentives behind these machinations are obvious. Corporations can extract significant concessions from American labor by threatening to move production facilities abroad. Further, corporations can avoid corporate taxes by moving to lower tax locations.

The motivations for these moves were distributional, yet the neoliberal economic theory insists that free trade is always efficient, and therefore invariably beneficial in the long run to the U.S. economy. Indeed, economic theory is clear that gains from trade only occur under specific assumptions. One such assumption is that no externalities exist. ${ }^{280}$ For example, if the United States closes manufacturing facilities because it can import Chinese manufactured goods more cheaply, there may be no gain if the relocation of U.S. manufacturing firms harms other domestic firms and industries. Gary Pisano and Willy Shih of Harvard Business School make the case that

\footnotetext{
277 The 1997 Asian Financial Crisis was due in part to the elimination of capital constraints by some Asian economies. See Joseph Stiglitz, Globalization and its Discontents, Norton (2002) at Ch. 4; Joe Studwell, How Asia Works: Success and Failure in the World's Most Dynamic Region, Grove (2013), Part 3.

${ }^{278}$ Dumenil \& Levy, The Crisis of Neoliberalism, Harvard U.P. (2011) at 114-115.

279 The growth in financial capital movements has also caused damage to developing countries with inadequate capital controls. Dani Rodrik, The Globalization Paradox: Democracy and the Future of the World Economy, Norton (2011) at 108-109 ("The mid-1990s saw another round of financial crises, the most severe of which was the 'tequila crisis' in Mexico (194) brought on by a sudden reversal in capital flows. The Asian financial crisis followed in 1997-98, which would then spill over to Russia (1998), Brazil (1999), Argentina (2000), and eventually Turkey (2001). These are only the better-known cases. One review identified 124 banking crises, 208 currency crises, and 63 sovereign debt crises between 1970 and 2008").

${ }^{280}$ Ian Fletcher, Free Trade Doesn't Work: Why America Needs a Tariff, U.S. Bus. and Ind. Council (2009) at 106; Dani Rodrik, The Globalization Paradox: Democracy and the Future of the World Economy, Norton (2011) at 53.
} 
clustered manufacturing such as in California's Silicon Valley creates a complex web of collective $R \& D$, engineering and manufacturing that facilitates innovation. They argue that the offshoring of manufacturing necessarily leads to migration of $R \& D$, suppliers, employee talent, and other complementary inputs. Pisano and Shih show how government policy is critically important to protect and nurture the "industrial commons" and the United States has reduced such support compared to other countries in the neo-liberal era. ${ }^{281}$

The Stolper-Samuelson Theorem in economics holds that trade will always involve absolute harm to some groups. ${ }^{282}$ According to Harvard trade economist Dani Rodrik "In a wealthy country such as the United States, these are likely to be unskilled workers such as high school dropouts. This renders the whole notion of 'gains from trade' suspect, since it is not at all clear how we can decide whether a country as a whole is better off when some people gain and others lose." 283 The estimated gains from moving to full free trade are small, less than 1 percent of GDP. ${ }^{284}$ Yet the impact on distribution can be many orders of magnitude larger. ${ }^{285}$ Of course

${ }^{281}$ Id. at 88-90; Gary Pisano and Willy Shih, Producing Prosperity: Why America Needs A Manufacturing Renaissance, Harvard Bus. Rev. (2012) at 17 ("As each company makes such a decision [to offshore], it becomes increasingly difficult for existing suppliers to stay in business. Investing in new technologies or training workers becomes less economically feasible. This lack of investment in technological and human resources leads to further erosion in competitive performance, which makes it even more attractive for other companies to move their supply base overseas. The process looks like a natural reaction to market forces, but, in fact, it was driven by some very specific management decisions.").

${ }^{282}$ See Josh Bivens, Everybody Wins Except Most of US: What Economics Teaches About Globalization, EPI (2008) at 33.

${ }^{283}$ Dani Rodrik, The Globalization Paradox: Democracy and the Future of the World Economy, Norton (2011) at 56.

${ }^{284}$ Lower wages are a prediction of free trade even in neoliberal economic theory. See John Bivens, Everybody Wins Except for Most of Us: What Economics Teaches About Globalization, EPI (2008) at Ch. 3; Paul Krugman, "Inequality and Redistribution" in The Washington Consensus Reconsidered: Towards a New Global Governance, Narcis Serra and Joseph Stiglitz ed., Oxford (2008); James K. Galbraith, Inequality What Everyone Needs to Know, Oxford (2016) at 76-78.

${ }^{285}$ Dani Rodrik, The Globalization Paradox: Democracy and the Future of the World Economy, Norton (2011) at 57-60. 
there are many contributing factors to inequality. ${ }^{286}$ However, Tim Noah estimates that "[t]rade with low-wage nations, which was negligible until the twenty-first century is responsible for 12 to 13 percent of the Great Divergence [rising inequality], and perhaps more."287 It is also questionable whether developing countries themselves are better off from free trade. Successful development has historically required industrial and tariff policies and the regulation of financial interests. $^{288}$

\section{b. $\quad$ Financialization of the Economy}

An important consequence of neoliberalism has been a financialization of the economy, reminiscent of that of the 1920s, but on a larger scale. No longer constrained by New Deal controls, the size, power and profitability of the financial sector has grown to unprecedented proportions in the neoliberal era. ${ }^{289}$ The share of the finance and insurance industry in GDP in

${ }^{286}$ Giovanni Peri, "Immigrants, Productivity and Labor Markets," 30 J. of Econ Persp. 3 (2016) (discussing the impact of immigration on wage inequality); Eric Brynjolfsson and Andrew McAfee, The Second Machine Age, Norton (2016) (discussing the impact of technology on inequality); Claudia Goldin and Lawrence Katz: The Race Between Education and Technology, Belknap (2010) (exploring the impact of education on income inequality); Josh Bivens, Everybody Wins Except for Most of Us: What Economics Teaches About Globalization, EPI (2008) (summarizing the literature on trade and inequality); Frank Levy and Peter Temin, "Inequality and Institutions in the $20^{\text {th }}$ Century" NBER Working Paper 13106 (2007) (describing the impact of government and institutional change on inequality).

287 Tim Noah, The Great Divergence America's Growing Inequality Crisis and What We Can do About It, Bloomsbury (2012) at 106. Ian Fletcher estimates that $25 \%$ of the growth in inequality is trade related. Ian Fletcher, Free Trade Doesn't Work: Why America Needs a Tariff, U.S. Business and Industrial Council (2009) at 36 ("Taking an approximate mean of available estimates, we can assign perhaps 25 percent of America's recent rise in income inequality to freer trade").

${ }^{288}$ Ha-Joon Chang, Kicking Away the Ladder: Development Strategy in Historical Perspective, Anthem (2003). Joe Studwell has shown that the key differences between successful developing countries and unsuccessful developing countries are (1) land reform (2) state led industrial policy (3) discipline through exports and (4) suppression of the financial sector. Joe Studwell, How Asia Works: Success and Failure in the World's Most Dynamic Region, Gove (2013). A similar analysis can be found in Joseph Stiglitz, "Is there a Post-Washington Consensus?" in Narcis Serra and Joseph Stiglitz, The Washington Consensus Reconsidered Toward a New Global Governance, Oxford (2008). This is not to say that countries such as China and India have not benefitted from the ability to export to the United States. But surely the relative success of China under the Communist Party is not a model of neoliberal policy.

${ }^{289}$ For a basic overview of financialization see Thomas I. Palley, "Financialization: What it is and why it matters," in Finance-Led Capitalism? Macroeconomic Effects of Changes in the Financial Sector, Eckhard Hein et al. ed., Metropolis-Verlag (2009); Greta R. Krippner, "The financialization of the American economy", 3 Soc-Econ Rev. 
the United States grew sharply after 1974, rising from approximately $4.5 \%$ to just below $9 \%$ by $2010 .^{290}$ Under the New Deal policy regime, nonfinancial corporate profits exceeded financial profits, whereas under neoliberalism this relationship was reversed. By 1985, the financial sector had greater profitability. ${ }^{291}$ The two main contributing factors to this reversal were the growth of debt and the rise in interest rates. The real rate of interest under the Reagan Administration was $6.8 \%$ (compared to less than $2 \%$ in the 1970 s) with a high of $8.7 \%$ in $1981 .{ }^{292}$ The net debt (borrowing minus lending) of nonfinancial firms grew from 79\% of GDP in 1952 to $192 \%$ of GDP in $2008 .^{293}$ As in the 1920 s, financial interest engineered a booming stock market. As Dumenil \& Levy describe, "taking the first quarter of 1980 as 1, the New York Stock Exchange (NYSE) index peaked at 5.45 in the third quarter of 2000, prior to the crash in 2000-2001.,"294

\section{Prerequisites for Financialization}

Financialization could not have occurred without at least four important legal transformations: banking deregulation, lax merger enforcement, relaxation of labor protections, and the rise of the shareholder value doctrine in corporate law. Following sixty years of successful banking regulation, a series of regulatory changes lifted the traditional banking restrictions. Jill Hendrickson described the successive banking acts that unraveled the New Deal

173 (2005); Gerald A. Epstein, "Introduction: Financialization and the World Economy," in Financialization and the World Economy, Gerald A. Epstein ed., Edward Elgar (2005).

${ }^{290}$ Thomas Philippon, "Has the U.S. finance Industry Become Less Efficient? On the Theory and Measurement of Financial Intermediation," NBER Working Paper 18077 (2012) at 8; Apostolos Fasianos, Diego Guevara \& Christos Pierros, "Have We Been Here Before? Phases of Financialization within the $20^{\text {th }}$ Century in the United States", Levy Economics Institute, Working Paper No. 869, June 2016 at 9.

${ }^{291}$ This data is displayed in figure 4.6 in Dumenil \& Levy, The Crisis of Neoliberalism, Harvard U.P. (2011) at 67.

${ }^{292}$ Two real interest rate series are displayed in figure 4.2 in Dumenil \& Levy, The Crisis of Neoliberalism, Harvard U.P. (2011) at 60.

${ }^{293} I d$. at 105.

${ }^{294} I d$. at 65 . 
regulatory apparatus. ${ }^{295}$ In 1980, Congress passed the Depository Institutions Deregulation and Monetary Control Act, which phased out regulation Q and allowed banks to pay interest on demand accounts. The Depository Institutions Act of 1982, among other things, sanctioned certain cross state mergers by banks. The Competitive Equality in Banking Act of 1987 expanded the ability of banks to acquire non-healthy banks across state lines. The Federal Deposit Insurance Corporation Improvement Act of 1991 initiated the process of removing the separation between investment and commercial banking for certain well-capitalized banks. The culmination of these deregulation processes was the passage in 1994 of the Neegle-Neal Interstate Banking and Branding Efficiency Act, removing restrictions on interstate banking, and the 1999 wholesale repeal of the Glass Steagall Act by the Gramm-Leach-Bliley Act in $1999 .^{296}$

Lax merger control also benefited financialization. The merger movements beginning in the 1980s were supported by debt, helping to push corporate leverage to historic highs. ${ }^{297}$ The logic of the corporate takeover movement further demanded that nonfinancial firms keep their share values high. Firms turned to share buybacks, which exploded in the 1980 s following the SEC revision of 10b-18 in 1982. ${ }^{298}$ Payment in the form of stock options to corporate directors

\footnotetext{
295 Jill Hendrickson, Regulation and Instability in U.S. Commercial Banking: A History of Crisis, Palgrave (2011) at $180-187$.

296 The events are recounted by Gerald F. Davis, Managed by the Markets: How finance re-Shaped America, Oxford U.P. (2009); and Greta R. Krippner Capitalizing on Crisis: The Political Origins of the Rise of Finance, Harvard U.P. (2011). See also, Jill M. Hendrickson, Regulation and Instability in U.S. Commercial Banking: A History of Crisis, Palgrave-Macmillan (2011); Mathew Sherman, "A Short History of financial Deregulation in the United States," Center for Economic and Policy Research, July 2009.

${ }^{297}$ James Crotty, “The Neoliberal Paradox: The Impact of Destructive Product Market Competition and 'Modern' Financial Markets on Nonfinancial Corporation Performance in the Neoliberal Era," in Gerard A. Epstein, Financialization and the World Economy, Edward Elgar (2005) at 90.

${ }^{298}$ Prior to 1982 share buy backs were not legal. Lenore Palladino, "The \$1Trillion Question: New Approaches to Regulating Stock Buybacks,” 36 Yale J. on Reg. Bull. 89 (2018); William Lazonick and Mary O’Sullivan, "Maximizing Shareholder Value: A New Ideology for Corporate Governance" in Corporate Governance and Sustainable Prosperity, William Lazonick et al. ed., Levy Institute (2002) at 23 (presenting data on historical pattern of corporate buybacks); Detailed data on share buybacks are also displayed in figure 4.4 in Dumenil \& Levy, The Crisis of Neoliberalism, Harvard U.P. (2011) at 63.
} 
and officers incentivized their focus on the stock market performance of the firm. ${ }^{299}$ Moreover, banking consolidation increased the power of the banking sector. More than six thousand bank mergers, ${ }^{300}$ reviewed by both the Federal Reserve and the Department of Justice occurred between 1980 and 1994. ${ }^{301}$ Carl Bogus has concluded after a review of the post-merger evidence on bank mergers that "researchers [are] divided on whether mergers between larger banks had no effect on efficiency whatsoever or whether mergers actually made banks less efficient, increasing their operating costs without improvements in service." ${ }^{302}$ Despite these facts, the antitrust agencies did not challenge any significant bank merger and ignored any concerns about too big to fail as irrelevant to their mission. ${ }^{303}$

Finally, changes to the corporate law removed obstacles to hostile takeovers. Incumbent boards of directors opposed many takeovers. These directors could use a variety of mechanisms to prevent a takeover including use of so-called poison pills. The Delaware Courts made an important policy choice by removing this obstacle under the justification of the shareholder value theory, the neoliberal theory that the sole purpose of the corporation is to increase shareholder value. Arguably, the critical decision supporting this viewpoint came in Revlon, Inc. $v$. MacAndrews \& Forbes Holdings, Inc, 506 A.2d 173 (Del. 1985) which held that the goal of the

\footnotetext{
299 Timothy Noah, The Great Divergence, America's Growing Inequality Crisis and what we can do about it, Bloomsbury Press (2012) at 151 - 156; Joseph E. Stiglitz, The Price of Inequality: How Today's Divided Society Endangers Our Future, Norton (2012) at 108-114.

${ }^{300}$ Carl Bogus, "The New Road to Serfdom: The Curse of Bigness and the Failure of Antitrust," 49 Mich. J. of Law Reform 1, 86 (2015); There have been hundreds of important bank mergers which have resulted in a handful of large interconnected banks that have been deemed "too big to fail." Jonathan Tepper and Denise Hearn, The Myth of Capitalism: Monopolies and the Death of Competition, Wiley (2019) at 127-128 (listing Wells Fargo, Bank of America, JP Morgan and Citigroup control 44\% of all assets held by US Banks); Frederic Scherer, "A Perplexed Economist Confronts 'Too Big to Fail”” Harvard Working Paper, March 2010 at Figure 1.

${ }^{301}$ See discussion in Maurice Stucke \& Allen Grunes, Big Data and Competition Policy, Oxford (2016) at 240-249.

${ }^{302}$ Carl Bogus, "The New Road to Serfdom: The Curse of Bigness and the Failure of Antitrust," 49 Mich. J. of Law Reform 1, 86 (2015).

${ }^{303}$ Bank mergers resulting in only five banks controlling $44 \%$ of all banking assets. Jonathan Tepper and Denise Hearn, The Myth of Capitalism: Monopolies and the Death of Capitalism, Wiley, (2019) at 127-128.
} 
corporation is shareholder profit maximization and limited the ability of firms to prevent corporate raiders. $^{304}$

Finally, David Weil showed how pressure from the financial sector has led to new strategies to reduce the costs of wages, safety compliance, training, benefits and other costs through a process he labeled "fissuring."305 Fissuring involves subcontracting subcategories of activities to other service providers who take responsibility for labor law compliance and wage setting. ${ }^{306}$ For example, according to Weil "[b]y 2000 an estimated $45 \%$ of janitors worked under contracting arrangements and more than $70 \%$ of guards were employed as contractors.",307 As Weil demonstrated, the fissured workplace did not require new regulation so much as it required making enforcement of existing labor regulation impossible through defunding, ${ }^{308}$ agency decisions, ${ }^{309}$ and an inability to update legislation to address these issues. ${ }^{310}$ Thus several

${ }^{304}$ William Lazonick and Mary O’Sullivan, "Maximizing Shareholder Value: A New Ideology for Corporate Governance" in Corporate Governance and Sustainable Prosperity, William Lazonick et al. ed., Levy Institute, (2002) at 16 ("The ideology of the market for corporate control lent powerful support to the claim that such takeover activity was beneficial to the corporations involved and indeed to the U.S. economy as a whole"); William David Yosifon also cites evidence that the Revlon decision was influenced by the neoliberal literature promoting the market for corporate control. See David Yosifon, Corporate Fiction: How Corporate Law Impedes American Progress and What to do About It, Cambridge U.P. (2018). See also, Leo E. Strine, Jr. "The Story of Blasius Industries v. Atlas Corp.: Keeping the Electoral Path to Takeovers Clear" in Corporate Law Stories, Foundation Press (2009); Adam Winkler, We the Corporations: How American Businesses Won Their Civil Rights, Lightright, (2018).

${ }^{305}$ Weil's thesis is supported by Jang-Sup Shin, "The Subversion of Shareholder Democracy and the Rise of Hedge Fund Activism," INET working paper No. 77, July, 2018.

${ }^{306}$ For an exhaustive sectorial analysis of the causes of wage stagnation see Lance Taylor and Ozlem Omer, "Race to the Bottom: Low Productivity, Market Power, and Lagging Wages," INET Working Paper 80, August 8, 2018.

${ }^{307}$ David Weil, The Fissured Workplace: Why Work has Become so Bad for so Many and What can be Done to Improve it, Harvard (2014) at 56.

${ }^{308}$ Id at 216 ("While real expenditures for overall enforcement stagnated for much of the past two decades, the number of workplaces and workers in the U.S. economy grew, increasing from 6.94 million establishments in 1998 to 7.71 million in $2007 \ldots$..”.

${ }^{309}$ Id at 185-186 ("The more the workplace has fissured, the more the subtleties raised by definitions of employment matter. In effect, what was at one time at the edges of disputes regarding idiosyncratic occupations (newsies) or historically fissured industries (construction and garments) has become a mainstream problem of employment, making the subtleties of these statutes more central to seeing that the objectives of workplace laws are achieved.").

${ }^{310}$ Id at 289 ("A positive path forward requires revisions of existing workplace laws so that they adequately recognize the far more complex nature of the modern workplace..."). 
important legal transformations were necessary for the rise to economic dominance of the financial sector under neoliberalism.

\section{The Impact of Financialization: Diversion of Profits to Finance}

Figure 2 comes from a recent paper by Gérard Duménil and Dominique Levy in which they demonstrate that the primary effect of the process of financialization has been to divert profits away from productive uses by non-financial corporations. ${ }^{311}$ As shown earlier, neoliberalism has led to an increase in profits, a result of lower wages and lax antitrust enforcement. The dark line on Figure 2 depicts the raise in corporate profits. However, these profits have been siphoned off to the high incomes of corporate executives and top-level managers, higher interest payments to support corporate debt, and dividends and share buybacks aimed at increasing the corporation's stock value. The dotted line shows the remaining retained earnings, which are available for productive investment, innovation and growth. In contrast to total profits, retained earnings declined in the 1970s and now hovers around zero.

Figure 2

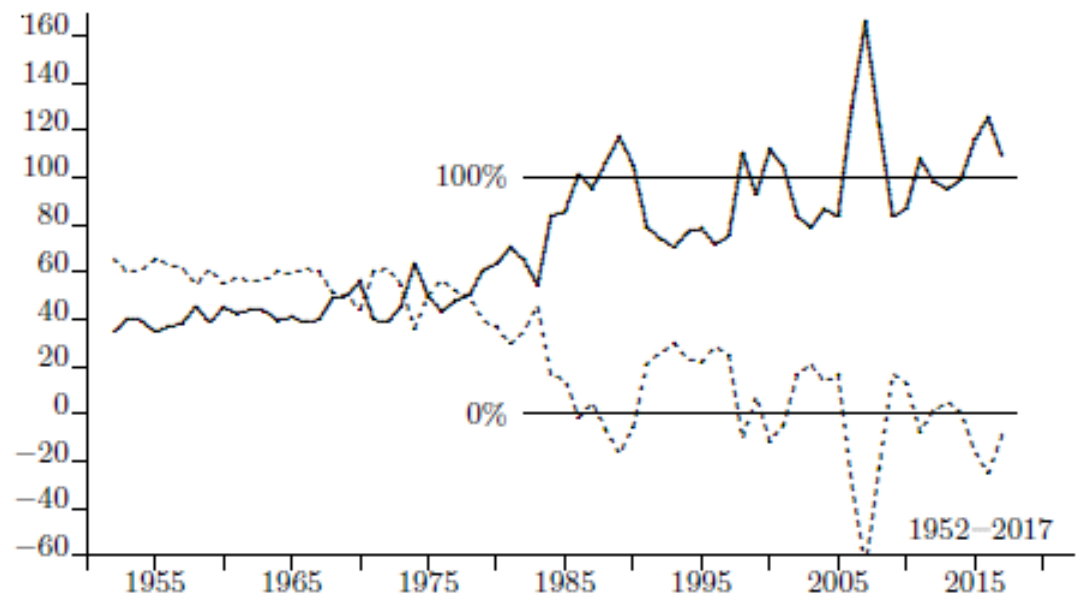

Distributed profits (interests, dividends, buybacks of stock shares): ( - ) Retained profits: (----)

311 See Gérard Duménil and Dominique Levy, "The changing patterns of income inequality in the United States (1917-2017) Upper wages center stage" Working Paper, January 2019 at 19. A similar graphic can be found in Jonathan Tepper, The Myth of Capitalism: Monopolies and the Death of Competition, Wiley (2019) at 57. 
Investment is highly correlated with retained earnings. ${ }^{312}$ The low and falling retained earnings helps explain why neoliberal policies have resulted in falling rates of investment and declining growth. ${ }^{313}$ In ironic contrast to the ostensible promises of trickledown theory of economic growth, neoliberal policies have been largely distributional in nature, reducing the income of the non-business classes only to divert resources away from productive investment into the consumption of the wealthy.

\section{c. An Assessment of Economic Performance under Neoliberalism}

Neoliberalism and the free market were supposed to bring economic prosperity by removing the unnatural influences of government and labor unions. The combination was supposed to create the optimal incentives for efficiency. Ostensibly, the hands off policy towards mergers would unleash the corporate dynamism and lead to greater growth and output. After four decades of such promises, the evidence shows that this new prosperity and dynamism is illusory. Compared with the Golden Age of Capitalism, the Age of Neoliberalism has turned in a dismal economic performance. Table 1 below compares the two periods on a variety of economic measures: ${ }^{314}$

\footnotetext{
${ }^{312}$ Gérard Duménil and Dominique Levy, The Crisis of Neoliberalism, Harvard (2011) at 152; Jonathan Lewellen and Katharina Lewellen, "Investment and Cash Flow: New Evidence," 51 J of Fin. \& Quant. Analysis 1135,1161 ("Our results suggest that investment and cash flow are strongly linked after controlling for a firm's investment opportunities...”).

${ }^{313}$ German Gutierrez and Thomas Philippon, "Declining Competition and Investment in the U.S.", March 2017 NBER working Paper; German Gutierrez and Thomas Philippon, "Investmentless Growth: An Empirical Investigation", BPEA Conference Drafts, September 7-8, 2017; Engelbert Stockhammer, "Financialisation and the slowdown of accumulation," 28 CJE 719 (2004); Ozgur Orhangazi, "The role of intangible assets in explaining the investment-profit puzzle," Forthcoming CJE (2018); Laurent Cordonnier and Franck Van de Velde, "The demands of finance and the glass ceiling of profit without investment," 39 CJE 871 (2014); Jay Shambaugh, Ryan Nunn, Audrey Breitwieser, and Patrick Liu, "The State of Competition, Start-ups, and Related Policies," The Hamilton Project, Brookings Inst. June 2018 at 13, Figure 5.

314 These are annual average rates of change. A similar conclusion comparing many more economic measures then presented here can be found in David Kotz, The Rise and Fall of Neoliberal Capitalism, Harvard (2017) at Chapter 4.
} 
Table $1^{315}$

\begin{tabular}{|c|c|c|c|c|c|c|c|}
\hline Year & $\begin{array}{c}\text { Real } \\
\text { GDP } \\
\text { Growth } \\
\text { Rate }\end{array}$ & $\begin{array}{c}\text { Profit } \\
\text { Rate }\end{array}$ & $\begin{array}{c}\text { Labor } \\
\text { Productivity } \\
\text { Growth } \\
\text { Rate }\end{array}$ & $\begin{array}{c}\text { Real } \\
\text { Wage } \\
\text { Growth } \\
\text { Rate }\end{array}$ & $\begin{array}{c}\text { Unemployment } \\
\text { Rate }\end{array}$ & $\begin{array}{c}\text { Investment } \\
\text { Growth } \\
\text { Rate }\end{array}$ & $\begin{array}{c}\text { Top 1\% } \\
\text { Share of } \\
\text { Income }\end{array}$ \\
\hline $\begin{array}{c}\text { Golden Age } \\
(1947-1973)\end{array}$ & 3.88 & 19.95 & 2.36 & 2.28 & 4.77 & 8.95 & 10.61 \\
\hline $\begin{array}{c}\text { Neoliberalism } \\
(1980-2015)\end{array}$ & 2.51 & 16.86 & 1.18 & 1.12 & 6.42 & 5.25 & 17.01 \\
\hline
\end{tabular}

Table 1 shows the superiority of economic performance in the golden age of capitalism under the New Deal policy regime. On average, GDP growth per year was more than a percentage point lower under neoliberalism than during the Golden Age. These levels of economic growth differences can have a massive impact on the ability of a society to increase the welfare of its citizens. Simultaneously, profits, wages and productivity were higher in the golden age than under neoliberalism. The higher earlier growth rate created the ability to invest more and reduce unemployment. Finally, neoliberalism has significantly heightened the income and wealth inequality, which is the root cause of many of our present social ills. ${ }^{316}$

Neoliberalism also delivered the Great Recession of 2008, the worst crisis since the Great Depression. However, it is significant that the Great Recession was contained, but not without great cost. This important improvement shows that the institutions that control the macroeconomy have become more effective since 1929. I leave as an open question whether neoliberalism has contributed to this improvement or rather whether it predated its rise to ideological dominance.

Finally, one cannot simply attribute the stronger performance in the golden age of capitalism to greater U.S. world domination following World War II. At the end of the war, the

\footnotetext{
${ }^{315}$ Data come from Appendix I and apply the definitions described therein; unemployment data begins in 1948.

316 In their book, The Spirit Level, Allen Lane (2009) Richard Wilkinson and Kate Pickett demonstrated how inequality is associated with a wide variety of social problems including physical and mental health, crime, drug abuse, education and social mobility.
} 
Marshall Plan transferred $\$ 13$ billion in U.S. grants (about 5\% of GDP in 1948) to rebuild Europe. There was comparatively little international trade, and the United States opened its markets to European exports on very favorable terms in order to facilitate American political goals. ${ }^{317}$ Thus, the root cause of the superiority of the golden age of capitalism lies elsewhere.

\section{Conclusion}

Antitrust has a long and storied history. What I have tried to demonstrate in this paper is that antitrust history is intimately connected to both economic history and the policies and ideologies attendant to economic history. This is contrary to a common perception that antitrust proceeds in a linear fashion by simply incorporating the theoretical and empirical findings of the economics profession. This linear approach does not accurately reflect how antitrust really evolved. Antitrust policy has changed relatively quickly in response to important economic upheavals such as the Great Depression or the crisis of the 1970s. The rise of the Chicago School had little to do with the brilliance of its participants and much more to do with the ideological policy shift from the New Deal policy structure to the rise of neoliberalism. However, policy also has consequences. The evidence shows that the New Deal policy regime resulted in superior economic performance and that neoliberalism that followed it has so far been a failure.

\footnotetext{
${ }^{317}$ Judith Stein, Pivotal Decade: How the United States Traded Factories for Finance in the Seventies, Yale U.P. (2010) at 6-7.
} 


\section{APPENDIX I* \\ HISTORICAL DATA FOR THE UNITED STATES}

\begin{tabular}{|c|c|c|c|c|c|c|c|}
\hline Year & $\begin{array}{c}\text { GDP } \\
\text { Growth } \\
\text { Rate }^{1}\end{array}$ & $\begin{array}{l}\text { Profit } \\
\text { Rate }^{2}\end{array}$ & $\begin{array}{c}\text { Labor } \\
\text { Productivity } \\
\text { Growth } \\
\text { Rate }^{3}\end{array}$ & $\begin{array}{c}\text { Real } \\
\text { Wage } \\
\text { Growth } \\
\text { Rate }^{4}\end{array}$ & $\begin{array}{c}\text { Unemployment } \\
\text { Rate }^{5}\end{array}$ & $\begin{array}{c}\text { Investment } \\
\text { Growth } \\
\text { Rate }^{6}\end{array}$ & $\begin{array}{c}\text { Income } \\
\text { Distribution }^{7}\end{array}$ \\
\hline 1869 & & 22.26518 & & & & & \\
\hline 1870 & 3.888133 & 20.91425 & 1.256388 & 2.308794 & & & \\
\hline 1871 & 3.906262 & 19.62218 & 1.24946 & 2.367492 & & & \\
\hline 1872 & 3.898272 & 18.40557 & 1.248754 & 2.394946 & & & \\
\hline 1873 & 3.888587 & 17.27916 & 1.247956 & 2.374577 & & & \\
\hline 1874 & 3.891356 & 16.24311 & 1.249585 & 2.332922 & & & \\
\hline 1875 & 3.892776 & 15.28932 & 1.251553 & 2.289616 & & & \\
\hline 1876 & 3.892994 & 14.4427 & 1.249251 & 2.170172 & & & \\
\hline 1877 & 3.894638 & 13.67071 & 1.247252 & 2.105377 & & & \\
\hline 1878 & 3.901496 & 12.99443 & 1.247664 & 1.981393 & & & \\
\hline 1879 & 3.897143 & 12.40441 & 1.242271 & 1.857121 & & & \\
\hline 1880 & 3.896746 & 11.88431 & 1.253594 & 1.768327 & & & \\
\hline 1881 & 3.886494 & 11.56548 & 1.244153 & 1.609752 & & & \\
\hline 1882 & 3.900952 & 11.30031 & 1.251867 & 1.5219 & & & \\
\hline 1883 & 3.89151 & 11.09454 & 1.246801 & 1.399479 & & & \\
\hline 1884 & 3.901929 & 10.94207 & 1.256781 & 1.300112 & & & \\
\hline 1885 & 3.890014 & 10.83158 & 1.242583 & 1.202819 & & & \\
\hline 1886 & 3.895448 & 10.75906 & 1.25007 & 1.137044 & & & \\
\hline 1887 & 3.888795 & 10.72074 & 1.246497 & 1.069682 & & & \\
\hline 1888 & 3.899606 & 10.71167 & 1.250686 & 1.015874 & & & \\
\hline 1889 & 6.159273 & 10.06742 & -0.73028 & 3.806937 & & & \\
\hline 1890 & 1.447839 & 7.642612 & -1.78955 & 3.297687 & & & \\
\hline 1891 & 3.249703 & 7.222657 & 0.714721 & 1.173382 & & & \\
\hline 1892 & 4.698342 & 6.934111 & 1.650582 & 1.686229 & & & \\
\hline 1893 & -0.0571 & 8.465991 & 0.273793 & -5.29504 & & & \\
\hline 1894 & -2.91272 & 8.193845 & -0.93454 & -3.14851 & & & \\
\hline 1895 & 11.71611 & 8.759567 & 6.269471 & 5.913617 & & & \\
\hline 1896 & -2.27618 & 7.523348 & -2.77366 & -0.12347 & & & \\
\hline 1897 & 8.158649 & 8.632387 & 5.111895 & 2.227667 & & & \\
\hline 1898 & 2.375261 & 9.572676 & 1.484886 & -1.71922 & & & \\
\hline 1899 & 11.62108 & 10.50052 & 5.259172 & 5.137498 & & & \\
\hline 1900 & 1.959908 & 10.36325 & 0.342654 & 0.668485 & & & \\
\hline 1901 & 12.24737 & 12.73219 & 7.737639 & 2.333852 & & & \\
\hline 1902 & 1.712131 & 10.45099 & -2.54112 & 4.662859 & & & \\
\hline 1903 & 2.868453 & 10.43737 & -0.09912 & -1.43296 & & & \\
\hline 1904 & 3.785977 & 11.98631 & 4.165092 & -0.14554 & & & \\
\hline
\end{tabular}




\begin{tabular}{|c|c|c|c|c|c|c|c|}
\hline Year & $\begin{array}{c}\text { GDP } \\
\text { Growth } \\
\text { Rate }^{1}\end{array}$ & $\begin{array}{l}\text { Profit } \\
\text { Rate }^{2}\end{array}$ & $\begin{array}{c}\text { Labor } \\
\text { Productivity } \\
\text { Growth } \\
\text { Rate }^{\mathbf{3}}\end{array}$ & $\begin{array}{c}\text { Real } \\
\text { Wage } \\
\text { Growth } \\
\text { Rate }^{4}\end{array}$ & $\begin{array}{c}\text { Unemployment } \\
\text { Rate }^{5}\end{array}$ & $\begin{array}{c}\text { Investment } \\
\text { Growth } \\
\text { Rate }^{6}\end{array}$ & $\begin{array}{c}\text { Income } \\
\text { Distribution }^{7}\end{array}$ \\
\hline 1905 & 9.182257 & 13.19194 & 4.368438 & 2.255648 & & & \\
\hline 1906 & 4.103802 & 12.93366 & 0.150507 & -0.41576 & & & \\
\hline 1907 & -1.5462 & 11.26981 & -3.82913 & 0.191328 & & & \\
\hline 1908 & -5.47301 & 9.408671 & -3.22947 & -0.4197 & & & \\
\hline 1909 & 11.65789 & 10.69321 & 6.228585 & 3.834633 & & & \\
\hline 1910 & 0.446336 & 9.461302 & -2.17113 & 1.51186 & & & \\
\hline 1911 & 3.182887 & 9.327098 & 1.580867 & 1.81436 & & & \\
\hline 1912 & 5.779305 & 10.59088 & 2.76886 & -0.41596 & & & \\
\hline 1913 & 3.9398 & 10.30697 & 2.416755 & 3.603482 & & & 17.960 \\
\hline 1914 & -7.57914 & 8.150906 & -6.51214 & -0.05604 & & & 18.158 \\
\hline 1915 & 3.702731 & 10.3724 & 3.189087 & -2.87479 & & & 17.578 \\
\hline 1916 & 16.22282 & 13.88474 & 9.090864 & 0.849676 & & & 19.311 \\
\hline 1917 & -0.02102 & 15.14681 & -1.84864 & -4.84891 & & & 17.737 \\
\hline 1918 & 7.694309 & 16.71971 & 6.817047 & 4.501972 & & & 15.961 \\
\hline 1919 & -2.89387 & 15.28263 & -2.93403 & 0.182148 & & & 16.411 \\
\hline 1920 & -2.12905 & 13.9462 & -2.3587 & 1.674654 & & & 14.830 \\
\hline 1921 & -3.52601 & 11.186 & 1.760153 & 7.132397 & & & 15.638 \\
\hline 1922 & 7.185968 & 11.19584 & 1.683008 & 4.283145 & & & 17.058 \\
\hline 1923 & 13.9893 & 13.8103 & 7.270208 & 3.732145 & & & 15.642 \\
\hline 1924 & 2.648673 & 15.55196 & 4.173012 & 1.428584 & & & 17.423 \\
\hline 1925 & 2.264671 & 15.44506 & -0.51497 & -0.04751 & & & 20.245 \\
\hline 1926 & 6.010101 & 16.44198 & 3.013485 & 1.697744 & & & 19.909 \\
\hline 1927 & 0.55321 & 14.3276 & 0.326308 & 4.234891 & & & 21.025 \\
\hline 1928 & 1.848337 & 13.99563 & 0.790927 & 1.028843 & & & 23.940 \\
\hline 1929 & 6.43442 & 15.46999 & 3.682883 & 2.637685 & & & 22.353 \\
\hline 1930 & -8.34801 & 10.75963 & -6.47461 & 0.841529 & & -25 & 17.223 \\
\hline 1931 & -6.44916 & 7.169111 & -3.29526 & 2.933656 & & -34.188 & 15.498 \\
\hline 1932 & -13.0926 & 2.621043 & -10.5131 & -2.22533 & & -45.4545 & 15.556 \\
\hline 1933 & -1.04069 & 3.777982 & 0.203267 & -3.62175 & & -11.9048 & 16.460 \\
\hline 1934 & 11.6836 & 7.640979 & \begin{tabular}{|l|}
9.129779 \\
\end{tabular} & 0.4854 & & 32.43243 & 16.397 \\
\hline 1935 & 8.759524 & 11.00091 & 8.469388 & 2.601717 & & 26.53061 & 16.676 \\
\hline 1936 & 13.01284 & 13.31983 & 9.102735 & 4.537567 & & 32.25806 & 19.288 \\
\hline 1937 & 6.115288 & 13.54358 & 3.222733 & 4.937871 & & 25.60976 & 17.149 \\
\hline 1938 & -3.91956 & 11.30905 & -2.09264 & 0.44606 & & -17.4757 & 15.755 \\
\hline 1939 & 8.390013 & 13.3115 & 7.076414 & 4.686851 & & 17.64706 & 16.175 \\
\hline 1940 & 9.214584 & 15.85071 & 6.687312 & 2.280767 & & 22 & 16.478 \\
\hline 1941 & 18.14316 & 20.44555 & 11.02436 & 5.523001 & & 22.95082 & 15.786 \\
\hline 1942 & 18.66695 & 24.74657 & \begin{tabular}{|l|}
10.65859 \\
\end{tabular} & 9.587941 & & -34 & 13.429 \\
\hline 1943 & 16.71773 & 28.86994 & 11.34662 & 11.05478 & & -17.1717 & 12.309 \\
\hline 1944 & 7.981359 & 31.45118 & 7.393011 & 6.147365 & & 23.17073 & 11.281 \\
\hline
\end{tabular}




\begin{tabular}{|c|c|c|c|c|c|c|c|}
\hline Year & $\begin{array}{c}\text { GDP } \\
\text { Growth } \\
\text { Rate }^{1}\end{array}$ & $\begin{array}{l}\text { Profit } \\
\text { Rate }^{2}\end{array}$ & $\begin{array}{c}\text { Labor } \\
\text { Productivity } \\
\text { Growth } \\
\text { Rate }^{3}\end{array}$ & $\begin{array}{c}\text { Real } \\
\text { Wage } \\
\text { Growth } \\
\text { Rate }^{4}\end{array}$ & $\begin{array}{c}\text { Unemployment } \\
\text { Rate }^{5}\end{array}$ & $\begin{array}{c}\text { Investment } \\
\text { Growth } \\
\text { Rate }^{6}\end{array}$ & $\begin{array}{c}\text { Income } \\
\text { Distribution }^{7}\end{array}$ \\
\hline 1945 & -1.21154 & 28.203 & -0.5412 & 0.077336 & & 37.62376 & 12.516 \\
\hline 1946 & -11.5813 & 22.3483 & -10.9408 & -7.34334 & & 94.96403 & 13.277 \\
\hline 1947 & -0.94935 & 20.7089 & -1.62283 & -0.69176 & & 39.11439 & 11.955 \\
\hline 1948 & 4.316056 & 21.65223 & 3.472361 & 2.12551 & 3.75 & 18.56764 & 12.243 \\
\hline 1949 & -0.42564 & 19.89467 & 1.031842 & 2.584019 & 6.05 & -6.4877 & 11.727 \\
\hline 1950 & 9.105836 & 20.46601 & 7.203931 & 5.20852 & 5.21 & 21.5311 & 12.820 \\
\hline 1951 & 8.624865 & 22.1854 & 3.619803 & 2.233234 & 3.28 & 3.937008 & 11.787 \\
\hline 1952 & 3.620346 & 20.74857 & 1.395405 & 3.779313 & 3.03 & 1.893939 & 10.791 \\
\hline 1953 & 4.619408 & 20.25198 & 2.922083 & 4.43514 & 2.93 & 8.736059 & 9.902 \\
\hline 1954 & -0.73455 & 19.11074 & 0.959216 & 1.642579 & 5.59 & 2.564103 & 10.774 \\
\hline 1955 & 7.468725 & 20.29982 & 6.244993 & 3.728636 & 4.37 & 14.66667 & 11.058 \\
\hline 1956 & 2.427977 & 17.84673 & -0.37577 & 2.552561 & 4.13 & 7.122093 & 10.672 \\
\hline 1957 & 2.047522 & 17.38697 & 0.987334 & 1.108968 & 4.30 & 2.713704 & 10.161 \\
\hline 1958 & -0.9671 & 16.95008 & 0.905089 & 0.933169 & 6.84 & -5.81242 & 10.206 \\
\hline 1959 & 7.0032 & 18.47358 & 5.6873 & 4.29745 & 5.45 & 14.72651 & 10.647 \\
\hline 1960 & 2.448369 & 18.04042 & 0.611156 & 1.909602 & 5.54 & 1.711491 & 10.035 \\
\hline 1961 & 2.415274 & 18.41033 & 2.758972 & 1.922613 & 6.69 & 0.480769 & 10.641 \\
\hline 1962 & 6.026364 & 19.86189 & 4.653437 & 3.157682 & 5.57 & 8.732057 & 9.950 \\
\hline 1963 & 4.267577 & 20.5952 & 3.390723 & 2.471759 & 5.64 & 7.480748 & 9.917 \\
\hline 1964 & 5.655371 & 21.42662 & 4.301442 & 3.302106 & 5.16 & 9.825998 & 10.479 \\
\hline 1965 & 6.416959 & 22.72102 & 3.470394 & 1.581827 & 4.51 & 12.20876 & 10.892 \\
\hline 1966 & 6.502895 & 23.0581 & 2.605816 & 2.242697 & 3.79 & 8.471761 & 10.175 \\
\hline 1967 & 2.696272 & 21.51062 & -0.4127 & 1.078707 & 3.84 & 1.684533 & 10.738 \\
\hline 1968 & 4.852942 & 21.3943 & 2.465878 & 2.423388 & 3.56 & 11.37048 & 11.213 \\
\hline 1969 & 3.107118 & 19.89719 & -0.03633 & 2.089898 & 3.49 & 11.15619 & 10.351 \\
\hline 1970 & 0.163938 & 18.08156 & -0.57144 & 0.917011 & 4.98 & 2.189781 & 9.025 \\
\hline 1971 & 3.306497 & 18.8077 & 3.451554 & 1.232332 & 5.95 & 12.2619 & 9.399 \\
\hline 1972 & 5.227359 & 19.2685 & 2.680311 & 2.316713 & 5.60 & 16.11877 & 9.638 \\
\hline 1973 & 5.634331 & 19.66912 & 1.807384 & 0.938491 & 4.86 & 14.61187 & 9.162 \\
\hline 1974 & -0.21605 & 16.55715 & -2.65595 & -0.59243 & 5.64 & 3.784861 & 9.122 \\
\hline 1975 & 0.111203 & 16.84648 & 1.973569 & 0.360322 & 8.48 & 1.151631 & 8.873 \\
\hline 1976 & 5.444677 & 17.80061 & 3.381993 & 2.199354 & 7.70 & 16.16698 & 8.861 \\
\hline 1977 & 4.761725 & 17.79063 & 1.312217 & 1.638124 & 7.05 & 22.2803 & 9.025 \\
\hline 1978 & 5.68701 & 17.88442 & 0.844923 & 0.843365 & 6.07 & 20.91905 & 8.951 \\
\hline 1979 & 3.244663 & 16.91351 & -0.34127 & 0.740854 & 5.85 & 15.26734 & 9.958 \\
\hline 1980 & -0.14336 & 14.73623 & -1.72481 & 1.056155 & 7.18 & 2.817711 & 10.021 \\
\hline 1981 & 2.576503 & 15.096 & 1.111445 & -0.25579 & 7.62 & 12.11782 & 10.017 \\
\hline 1982 & -1.83206 & 13.02463 & -1.7651 & 1.974887 & 9.71 & -0.91453 & 10.796 \\
\hline 1983 & 4.169536 & 14.99425 & 3.934223 & 0.8617 & 9.60 & 7.954355 & 11.555 \\
\hline 1984 & 6.902083 & 16.83417 & 3.114598 & 0.810865 & 7.51 & 17.31696 & 11.989 \\
\hline
\end{tabular}




\begin{tabular}{|c|c|c|c|c|c|c|c|}
\hline Year & $\begin{array}{c}\text { GDP } \\
\text { Growth } \\
\text { Rate }^{1}\end{array}$ & $\begin{array}{l}\text { Profit } \\
\text { Rate }^{2}\end{array}$ & $\begin{array}{c}\text { Labor } \\
\text { Productivity } \\
\text { Growth } \\
\text { Rate }^{3}\end{array}$ & $\begin{array}{c}\text { Real } \\
\text { Wage } \\
\text { Growth } \\
\text { Rate }^{4}\end{array}$ & $\begin{array}{c}\text { Unemployment } \\
\text { Rate }^{5}\end{array}$ & $\begin{array}{c}\text { Investment } \\
\text { Growth } \\
\text { Rate }^{6}\end{array}$ & $\begin{array}{c}\text { Income } \\
\text { Distribution }^{7}\end{array}$ \\
\hline 1985 & 3.935943 & 17.10983 & 1.353194 & 1.264175 & 7.19 & 7.035908 & 12.669 \\
\hline 1986 & 3.490623 & 16.43249 & 1.156934 & 2.778903 & 7.00 & 4.307997 & 15.917 \\
\hline 1987 & 3.438141 & 15.88775 & 0.152089 & 1.58312 & 6.18 & 2.658438 & 12.662 \\
\hline 1988 & 4.112286 & 15.88759 & 1.13151 & 1.609486 & 5.49 & 6.184971 & 15.493 \\
\hline 1989 & 3.454641 & 16.91221 & 1.135416 & -0.64904 & 5.26 & 5.824714 & 14.486 \\
\hline 1990 & 1.642546 & 16.48924 & 0.102626 & 0.925747 & 5.62 & 0.709877 & 14.330 \\
\hline 1991 & -0.29432 & 16.07961 & -0.07129 & 0.77592 & 6.85 & -3.49372 & 13.361 \\
\hline 1992 & 3.220223 & 16.74459 & 3.901632 & 3.429804 & 7.49 & 5.504393 & 14.671 \\
\hline 1993 & 2.588779 & 17.27702 & 0.476863 & -0.42459 & 6.91 & 8.959567 & 14.237 \\
\hline 1994 & 3.970011 & 18.21976 & 1.530565 & -0.16005 & 6.10 & 9.825046 & 14.232 \\
\hline 1995 & 2.750251 & 17.96901 & -0.3179 & -0.05915 & 5.59 & 7.84774 & 15.234 \\
\hline 1996 & 3.546836 & 18.54864 & 2.117552 & 1.360619 & 5.41 & 8.940372 & 16.687 \\
\hline 1997 & 4.245303 & 18.69027 & 2.141661 & 2.295361 & 4.94 & 8.806109 & 18.015 \\
\hline 1998 & 4.234661 & 17.76568 & 1.828698 & 3.990536 & 4.50 & 9.726504 & 19.088 \\
\hline 1999 & 4.639465 & 17.73464 & 2.476367 & 2.604997 & 4.22 & 9.157203 & 20.044 \\
\hline 2000 & 4.00684 & 16.61923 & 1.483985 & 3.723811 & 3.97 & 8.635418 & 21.521 \\
\hline 2001 & 0.746558 & 15.92351 & -0.47376 & 0.021483 & 4.74 & -0.54438 & 18.220 \\
\hline 2002 & 1.54379 & 16.79231 & 2.576015 & 0.254089 & 5.78 & -3.17774 & 16.865 \\
\hline 2003 & 2.594986 & 17.80001 & 3.09685 & 1.328826 & 5.99 & 5.370603 & 17.528 \\
\hline 2004 & 3.73771 & 18.10428 & 3.074168 & 1.822726 & 5.54 & 10.14406 & 19.753 \\
\hline 2005 & 3.516523 & 18.33747 & 1.594501 & 0.028401 & 5.08 & 11.7265 & 21.916 \\
\hline 2006 & 2.774445 & 17.74725 & 0.61866 & 1.040581 & 4.61 & 6.248991 & 22.823 \\
\hline 2007 & 1.701158 & 17.11691 & 0.438599 & 1.392232 & 4.62 & 0.269757 & 23.503 \\
\hline 2008 & -0.33444 & 15.55044 & -1.00696 & 0.493818 & 5.80 & -5.00928 & 20.946 \\
\hline 2009 & -3.15041 & 15.69965 & 0.604472 & -0.23048 & 9.28 & -17.013 & 18.119 \\
\hline 2010 & 2.280131 & 17.13841 & 4.628802 & 1.728154 & 9.61 & 1.499712 & 19.863 \\
\hline 2011 & 1.513849 & 17.17417 & 0.649741 & 0.711382 & 8.93 & 8.273347 & 19.647 \\
\hline 2012 & 2.159052 & 17.47879 & 0.565347 & 0.521787 & 8.08 & 11.55579 & 22.828 \\
\hline 2013 & 1.662706 & 17.81014 & 0.270894 & -0.6506 & 7.36 & 6.704568 & 20.006 \\
\hline 2014 & 2.427724 & 17.83331 & -0.74766 & -0.37273 & 6.18 & 8.557781 & 21.429 \\
\hline 2015 & 2.531857 & 17.56698 & 1.24406 & 2.675244 & 5.27 & 4.359599 & 22.028 \\
\hline
\end{tabular}

*Columns 2-5 are from G. Duménil, D. Lévy, "The Historical Trends of Technology and Distribution in the U.S.

Economy. Data and figures (since 1869)."

Column 6 is from Federal Reserve Bank of St. Louis Database

Column 7 is from BEA, NIPA Table 1.1.5 line 8

Column 8 is constructed based on income tax statistics. Full details on the construction of the series are provided in appendix of Piketty and Saez (2006), available online at: http://emlab.berkeley.edu/users/saez/piketty-saezOUP04US.pdf

$\mathrm{GDPR}=\mathrm{GDP} /(\mathrm{p})$ 
NDP: Net Domestic Product in current dollars

NDPR: NDP in constant 2009 dollars

NDP Deflator: $\mathrm{p}=$ NDP/NDPR

W: Total compensation of workers in current dollars

Profit: $\Pi=$ NDP - W

$\mathrm{K}$ : Net stock of fixed capital in current dollars

L: Number of workers

$\mathrm{w}=\mathrm{W} / \mathrm{L}$

${ }^{1}$ Growth rate of real GDP: growth rate of GDPR

${ }^{2}$ Profit rate: Profit / Capital: $r=\Pi / K$

${ }^{3}$ Growth rate of labor productivity per worker: $\mathrm{P}_{\mathrm{L}}=\mathrm{NDP}^{\mathrm{R}} / \mathrm{L}$

${ }^{4}$ Growth rate of real Wages where theAnnual wage of a worker in constant 2009 dollars is $w^{R}=w / p$

${ }^{5}$ Civilian Unemployment Rate, Percent, Annual, Seasonally Adjusted

${ }^{6}$ Growth rate of gross Private Domestic Fixed Investment, Billions of Dollars

${ }^{7}$ Income share (including capital gains) of top $1 \%$ in the United States (fractiles are defined by total income including capital gains). 